Prepared in cooperation with the U.S. Fish and Wildlife Service

\title{
Water Resources of the Iroquois National Wildlife Refuge, Genesee and Orleans Counties, New York, 2009-2010
}
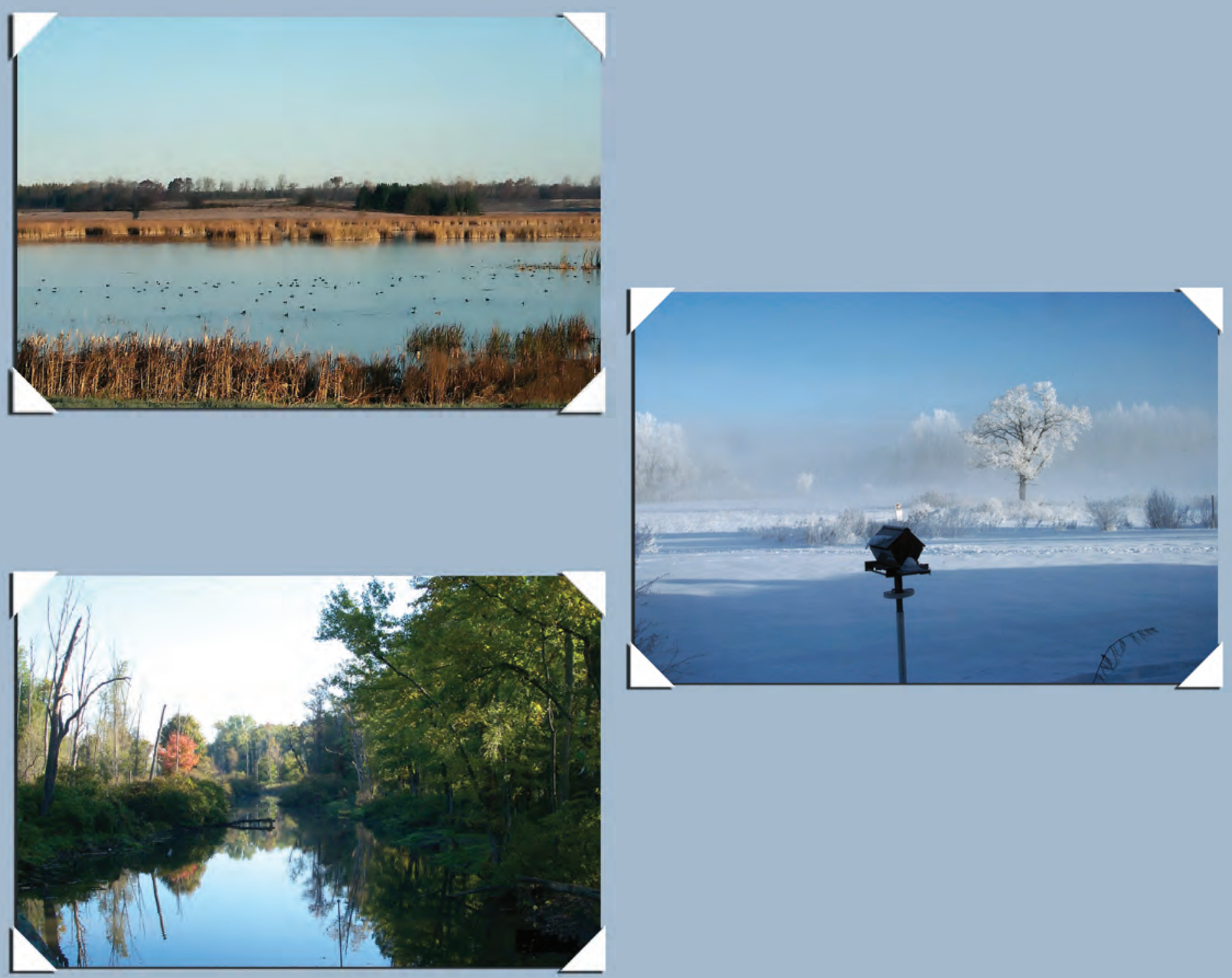

Scientific Investigations Report 2012-5027 
Cover. All photos from the Iroquois National Wildlife Refuge photo archives.

Upper Left - Cayuga Marsh overlook at NY-Route 77, autumn scene.

Right - Ice fog (hoar frost) view of wetland behind Iroquois Refuge office building along Casey Road, midwinter.

Lower left - Oak Orchard Creek looking downstream from Knowlesville Road, on the eastern side of the Refuge, early autumn. 


\section{Water Resources of the Iroquois National Wildlife Refuge, Genesee and Orleans Counties, New York, 2009-2010}

By William M. Kappel and Matthew B. Jennings

Prepared in cooperation with the U.S. Fish and Wildlife Service

Scientific Investigations Report 2012-5027 


\title{
U.S. Department of the Interior \\ KEN SALAZAR, Secretary \\ U.S. Geological Survey \\ Marcia K. McNutt, Director
}

\author{
U.S. Geological Survey, Reston, Virginia: 2012
}

For more information on the USGS - the Federal source for science about the Earth, its natural and living resources, natural hazards, and the environment, visit http://www.usgs.gov or call 1-888-ASK-USGS.

For an overview of USGS information products, including maps, imagery, and publications, visit http://www.usgs.gov/pubprod

To order this and other USGS information products, visit http://store.usgs.gov

Any use of trade, product, or firm names is for descriptive purposes only and does not imply endorsement by the U.S. Government.

Although this report is in the public domain, permission must be secured from the individual copyright owners to reproduce any copyrighted materials contained within this report.

Suggested citation:

Kappel, W.M., and Jennings, M.B., 2012, Water resources of the Iroquois National Wildlife Refuge, Genesee and Orleans counties, New York, 2009-2010: U.S. Geological Survey Scientific Investigations Report 2012-5027, 53 p., at http://pubs.usgs.gov/sir/2012/5027/. 


\section{Contents}

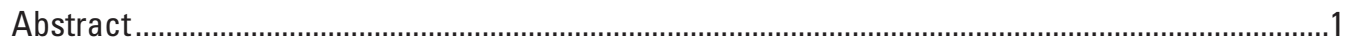

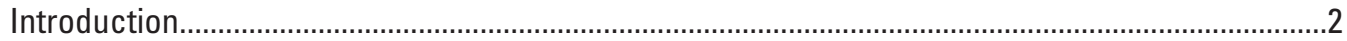

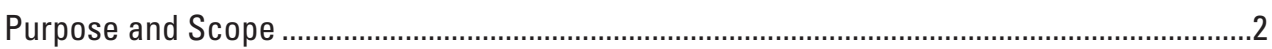

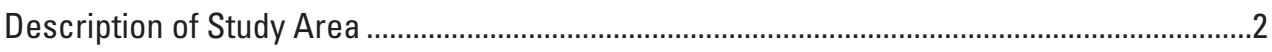

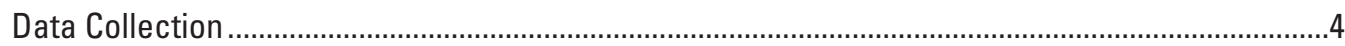

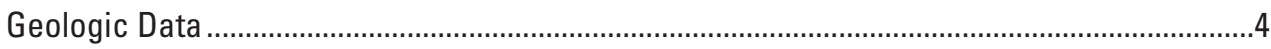

Well Inventory and Test Drilling ....................................................................................

Groundwater Level and Streamflow Measurements ..........................................................4

Water-Quality Sampling and Analyses...................................................................................

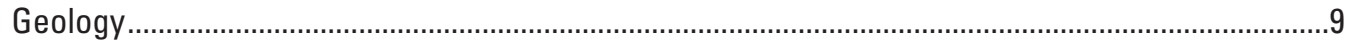

Bedrock Geology.

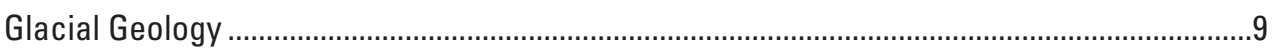

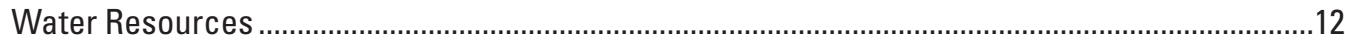

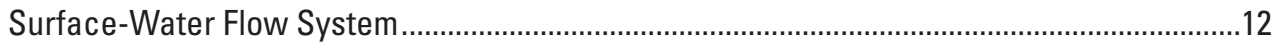

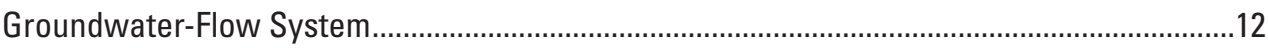

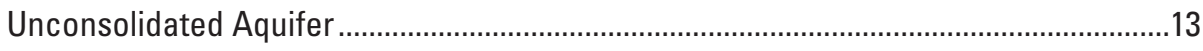

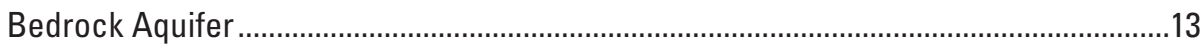

Well Hydrographs ................................................................................................

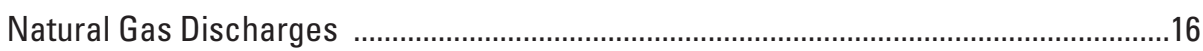

Bedrock Aquifer Response at Local Lockport Quarries.......................................................17

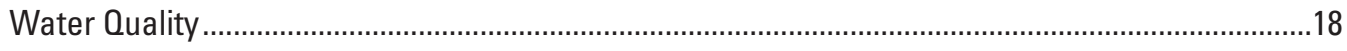

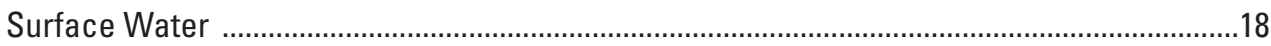

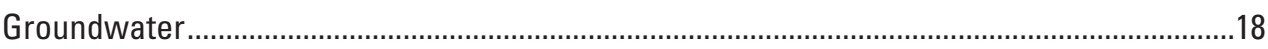

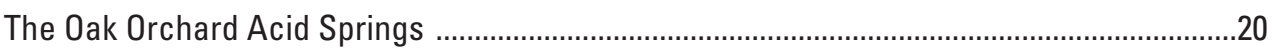

Water-Quality Concerns and the Proposed Lockport Quarry ...................................................20

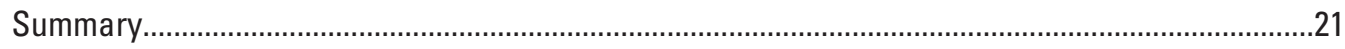

References Cited.

Appendix 1. Results of Water-Quality Analyses of Samples From Streams, Wells, and Springs in and around the Iroquois National Wildlife Refuge, November 2008 to November 2010. (Tables 1-1 through 1-10)...................................................................25

Appendix 2. Hydrographs of 17 Groundwater-Monitoring Wells in and around the Iroquois National Wildlife Refuge, 3 Regional Groundwater Wells, and 2 Stream Sites of Oak Orchard Creek at Sour Springs Road and Harrison Road, November 2008 to November 2010.

Appendix 3. Borehole geophysical logs for four test holes - OL27-Dunlap Road, OL37-0ak Orchard Ridge Road, OL38-Salt Road, and GS286-Sour Springs Road-drilled in the Iroquois National Wildlife Refuge, Genesee and Orleans Counties, New York. 


\section{Figures}

1. Map showing the location of the Iroquois National Wildlife Refuge and adjacent New York State Wildlife Management areas (WMAs). the Lockport Dolomite and Onondaga Limestone Escarpments, Lockport Dolomite quarries, and regional groundwater-level monitoring wells, Genesee, Orleans, and Niagara Counties, New York

2. Map showing the location of surface-water and groundwater sites and station numbers used for water-quality sampling and flow monitoring in and around the Iroquois National Wildlife Refuge, Genesee (GS) and Orleans (OL) Counties, New York

3. Photograph showing shale-packer assembly used to separate three Lockport Dolomite test holes into two monitoring intervals in the Lockport Dolomite bedrock, Genesee and Orleans Counties, New York.

4. Diagram showing stratigraphic columns for the western part of New York State showing the summary of geologic units near the Iroquois National Wildlife Refuge, Genesee and Orleans Counties, New York

5. Map showing the extent of Glacial Lake Tonawanda and the location of the Iroquois National Wildlife Refuge (red outline) in relation to the former Medina Spillway, which is also the present location of Oak Orchard Creek as it leaves the Refuge and crosses the Lockport (Niagara) Escarpment in Genesee and Orleans Counties, New York

6. Map showing the approximate water table and the general direction of groundwater flow in the unconsolidated and bedrock aquifers in the vicinity of the Iroquois National Wildlife Refuge, Genesee and Orleans Counties, New York ........14

7. Map showing approximate bedrock-surface contour and elevation in the vicinity of the Iroquois National Wildlife Refuge, Genesee and Orleans Counties, New York....15

8. Piper diagram of major cations and anions in surface-water and groundwater samples collected in and around the Iroquois National Wildlife Refuge, Genesee and Orleans Counties, New York, 2009-10.

\section{Tables}

1. Surface-water and groundwater sampling sites and station numbers at the Iroquois National Wildlife Refuge, Genesee and Orleans Counties, New York. 


\section{Conversion Factors, Datum, and Abbreviations}

\begin{tabular}{lcl}
\hline Multiply & By & To Obtain \\
\hline inch (in.) & Length & \\
inch (in.) & 2.54 & centimeter $(\mathrm{cm})$ \\
foot (ft) & 25.4 & millimeter $(\mathrm{mm})$ \\
mile (mi) & 0.3048 & meter $(\mathrm{m})$ \\
mile, nautical (nmi) & 1.609 & kilometer $(\mathrm{km})$ \\
yard (yd) & 1.852 & kilometer $(\mathrm{km})$ \\
\hline & 0.9144 & meter $(\mathrm{m})$ \\
\hline acre & Area & \\
acre & 4,047 & square meter $\left(\mathrm{m}^{2}\right)$ \\
\hline & 0.4047 & hectare $(\mathrm{ha})$ \\
\hline gallon (gal) & Volume & \\
gallon (gal) & 3.785 & liter $(\mathrm{L})$ \\
cubic foot ( $\left.\mathrm{ft}^{3}\right)$ & 0.003785 & cubic meter $\left(\mathrm{m}^{3}\right)$ \\
\hline & 0.02832 & cubic meter $\left(\mathrm{m}^{3}\right)$ \\
\hline cubic foot per second $\left(\mathrm{ft}^{3} / \mathrm{s}\right)$ & Flow rate & \\
gallon per minute $(\mathrm{gal} / \mathrm{min})$ & 0.02832 & cubic meter per second $\left(\mathrm{m}^{3} / \mathrm{s}\right)$ \\
gallon per day (gal/d) & 0.06309 & liter per second $(\mathrm{L} / \mathrm{s})$ \\
\hline
\end{tabular}

Vertical coordinate information is referenced to the National Geodetic Vertical Datum of 1929 (NGVD 29).

Horizontal coordinate information is referenced to the North American Datum of 1983 (NAD 83).

Elevation, as used in this report, refers to distance above the vertical datum.

Specific conductance is given in microsiemens per centimeter at 25 degrees Celsius $\left(\mu \mathrm{S} / \mathrm{cm}\right.$ at $\left.25^{\circ} \mathrm{C}\right)$.

\section{List of Acronyms}

DEIS Draft environmental impact statement

ET Evapo-transpiration

GPS Global Positioning System

NWQL National Water Quality Laboratory

NYSDEC New York State Department of Environmental Conservation

PVC Polyvinyl chloride

USGS U.S. Geological Survey

WMA Wildlife Management Area 
This page has been left blank intentionally. 


\title{
Water Resources of the Iroquois National Wildlife Refuge, Genesee and Orleans Counties, New York, 2009-2010
}

\author{
By William M. Kappel and Matthew B. Jennings
}

\section{Abstract}

A 2-year study of the water resources of the Iroquois National Wildlife Refuge (Refuge) in western New York was carried out in 2009-2010 in cooperation with the U.S. Fish and Wildlife Service to assist the Refuge in the development of a 15-year Comprehensive Conservation Plan. The study focused on Oak Orchard Creek, which flows through the Refuge, the groundwater resources that underlie the Refuge, and the possible changes to these resources related to the potential development of a bedrock quarry along the northern side of the Refuge. Oak Orchard Creek was monitored seasonally for flow and water quality; four tributary streams, which flowed only during early spring, also were monitored. A continuous streamgage was operated on Oak Orchard Creek, just north of the Refuge at Harrison Road. Four bedrock wells were drilled within the Refuge to determine the type and thickness of unconsolidated glacial sediments and to characterize the thickness and type of bedrock units beneath the Refuge, primarily the Lockport Dolomite. Water levels were monitored in 17 wells within and adjacent to the Refuge and water-quality samples were collected from 11 wells and 6 springs and analyzed for physical properties, nutrients, major ions, and trace metals.

Flow in Oak Orchard Creek is from two different sources. During spring runoff, flow from the Onondaga Limestone Escarpment, several miles south of the Refuge, supplements surface-water runoff and groundwater discharge from the Salina Group to the south and east of the Refuge. Flow to Oak Orchard Creek also comes from surface-water runoff from the Lockport Dolomite Escarpment, north of the Refuge, and from groundwater discharging from the Lockport Dolomite and unconsolidated deposits that overlie the Lockport Dolomite. During the summer and fall low-flow period, only small quantities of groundwater flow from the Salina shales and Lockport Dolomite bedrock and the unconsolidated sediments that overlie them; most of this flow is lost to wetland evapotranspiration, and the remainder enters Oak Orchard Creek. Water quality in the Oak Orchard Creek is affected not only by these groundwater sources but also by surface runoff from agricultural areas and the New York State Wildlife Management Area east of the Refuge.

Based on the results of the drilling program, the Lockport Dolomite underlies nearly all the Refuge. The Refuge wetlands lie within a bedrock trough between the Lockport Dolomite and Onondaga Limestone Escarpments, to the north and south, respectively. This bedrock trough was filled with mostly fine-grained sediments when Glacial Lake Tonawanda was present following the last period of glaciation. These fine-grained sediments became the substrate on which the wetlands were formed along Oak Orchard Creek and nearby Tonawanda Creek, to the south and west. Water quality in the unconsolidated and bedrock aquifers is variable; poor quality water (sulfide-rich "black water") generally is present south of Oak Orchard Creek and better quality water to the north where the Lockport Dolomite is close to the land surface. A set of springs, the Oak Orchard Acid Springs, is present within the Refuge; the springs are considered unique in New York State because of their naturally low $\mathrm{pH}$ (approximately 2.0) and their continual discharge of natural gas.

The potential development of a bedrock quarry in the Lockport Dolomite bedrock along the northern border of the Refuge may affect the nearby Refuge wetlands. The extent of drawdown needed to actively quarry the bedrock could change the local hydrology and affect groundwater-flow directions and rates, primarily in the Lockport Dolomite bedrock and possibly the Oak Orchard Acid Springs area, farther to the south. The effect on the volume of flow in Oak Orchard Creek would probably be minimal as a result of the poor interaction between the surface-water and the groundwater systems. Of greater potential effect will be the possible change in the quality of water flowing into the Refuge from the discharge of groundwater during dewatering operations at the quarry; this discharge will flow into the northern part of the Refuge and affect the quantity and quality of wetland areas downstream from the quarry discharge. These changes may affect wetland management activities because of the potential for poorquality water to affect the ecology of the wetlands and the wildlife that use these wetlands. 


\section{Introduction}

In fall 2008, the U.S. Geological Survey (USGS), in cooperation with the U.S. Fish and Wildlife Service-Iroquois National Wildlife Refuge, (referred to throughout this report as the "Refuge") commenced a study of the surface-water and groundwater resources within and surrounding the Refuge in western New York. The Refuge straddles the boundary between Genesee and Orleans Counties in northwestern New York, and is located between the cities of Rochester, N.Y., to the east and Buffalo, N.Y., to the west. On either side of the Refuge, the New York State Department of Environmental Conservation (NYSDEC) maintains wildlife management areas along Oak Orchard Creek to the east of the Refuge and adjacent to Tonawanda Creek to the southwest of the Refuge (fig. 1).

The Iroquois National Wildlife Refuge was created in 1958 as the Oak Orchard National Wildlife Refuge but was renamed Iroquois National Wildlife Refuge in 1964 so as to not confuse it with the neighboring New York State Oak Orchard Wildlife Management Area (WMA). These wildlife management areas serve the western portion of the Atlantic Flyway (a major water-fowl and song-bird migration route) and the Refuge encompasses more than 10,200 acres of land, including forest, grassland, emergent marsh, and hardwood swamp. These habitats serve as nesting, resting, staging, and feeding areas for 268 species of migratory birds, including many threatened and endangered species in the State. The Refuge is also a year-round home to hundreds of species of birds, mammals, amphibians, fish, reptiles, and insects: (Iroquois National Wildlife Refuge, undated).

In 2010, the Refuge began the development of a 15-year Comprehensive Conservation Plan that will serve as a guide to current and future management of the various habitats that support numerous species of migratory and permanent wildlife that use the Refuge. The interconnection of the surface-water and groundwater systems affects water levels and wildlife- and habitat-management operations within the Refuge. An issue of importance to future comprehensive conservation planning is a proposed bedrock quarry along the Refuge's northern border. This quarry has the potential to affect the natural hydrology of the Refuge and the water quality of its wetlands, streams, springs, and Oak Orchard Creek, which flows through the middle of the Refuge.

\section{Purpose and Scope}

This report describes the hydrogeology of the unconsolidated glacial deposit and underlying bedrock aquifers within and near the Refuge and includes descriptions of (1) the glacial and bedrock geology; (2) the groundwaterflow system, including water levels and groundwater and surface-water interaction; and (3) the water quality of both surface water and groundwater, including nutrients and common ions. Also included in this report are figures and tables that indicate the location of (1) wells used to determine groundwater level and groundwater quality in the unconsolidated and bedrock aquifers; (2) streamflow sites used to determine flow and collect water-quality samples; (3) results of water-quality analyses for surface water and groundwater; and (4) hydrographs of water-level fluctuations in 17 wells in and around the Refuge and at three other regional locations, in addition to stage hydrographs for Oak Orchard Creek at Sour Springs and Harrison Roads.

\section{Description of Study Area}

The Iroquois National Wildlife Refuge is located on the Lake Ontario Plain about 15 miles south of Lake Ontario (fig. 1). The wetlands, which are partly within the State and Federal wildlife management areas, are also within the boundary of former Glacial Lake Tonawanda, which existed about 10,000 years ago as glacial ice was receding into Canada. This glacial lake initially extended from the present-day Niagara River, eastward through the Refuge to near Holley, N.Y. (fig. 1), as described in greater detail in a "Glacial Geology" section. As the glacial ice receded north, the Earth's surface slowly rebounded, and the glacial lake began to shrink in size from east to west until the entire lake drained at the Niagara River Gorge, leaving a flat lacustrine clay and silt lakebed where the State and Federal wetlands are present today.

The glacial lake was bounded on the south by the Onondaga Limestone Escarpment and on the north by the Lockport Dolomite Escarpment. Between these two carbonate rock units lie the shales and evaporites of the Salina Group, which are more easily eroded by glacial activity than the carbonate bedrock. A natural east-west trending bedrock trough was created in which the glacial lake formed and the wetlands presently reside. The Refuge complex lies on the northern side of the glacial lake, therefore most of the Refuge overlies the Lockport Group. Further to the south, the remaining wetland and upland areas overlie the Salina Group. The glacial landforms include silty clay bottomlands; clayey, silty, and sandy beach ridges; and some small till-cored moraines. To the north of the Refuge, the Lockport Dolomite crops out at land surface and forms the Lockport Escarpment in this area.

Oak Orchard Creek rises near the Onondaga Limestone Escarpment, flows into the southeastern edge of former Glacial Lake Tonawanda, and continues northwestward into the Refuge. The creek then turns north toward Shelby, N.Y., and follows the former Medina Spillway of Glacial Lake Tonawanda over the Lockport Escarpment, gaining additional flow from its remaining watershed as the creek flows to Lake Ontario at Point Breeze, N.Y. (fig. 1). 


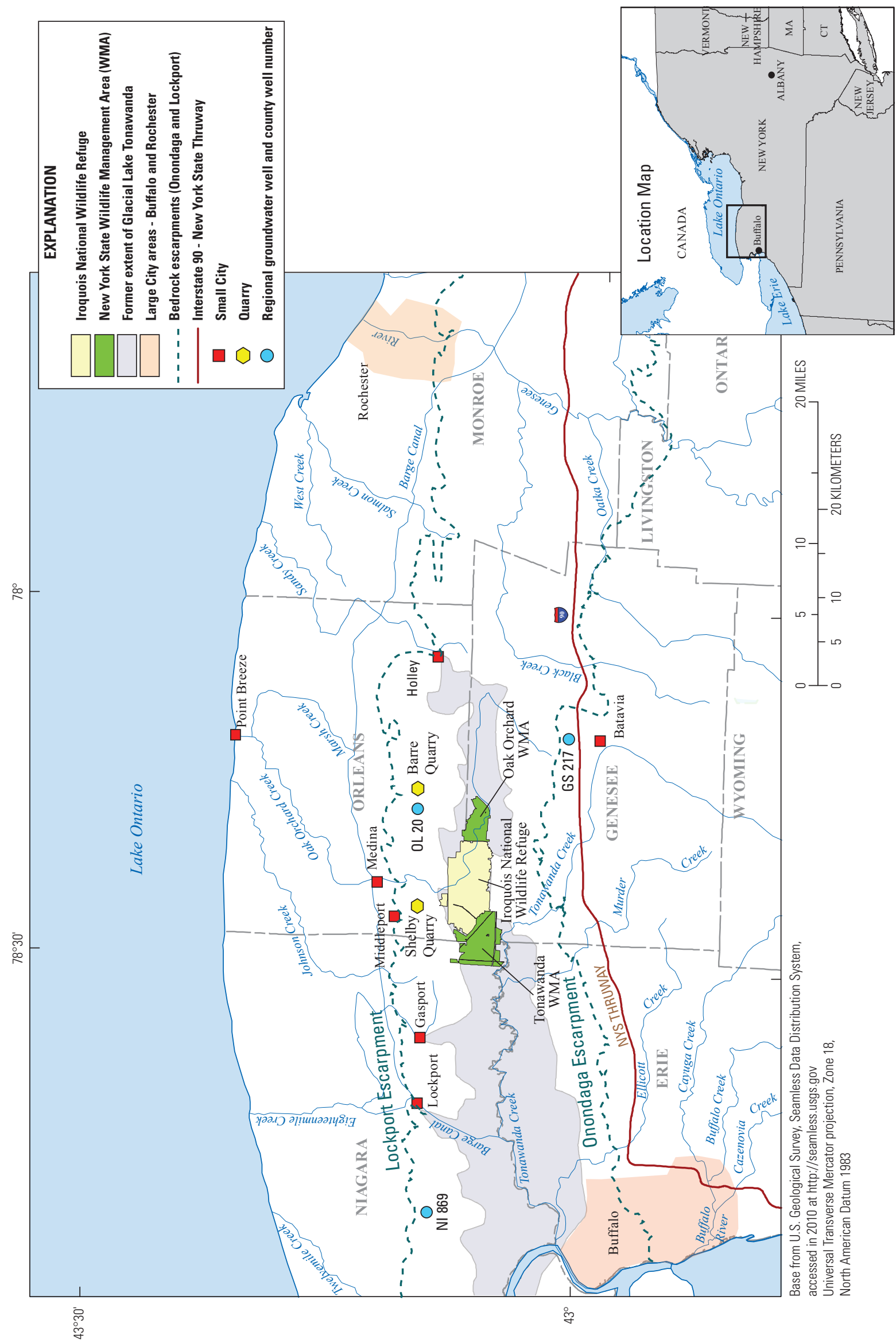

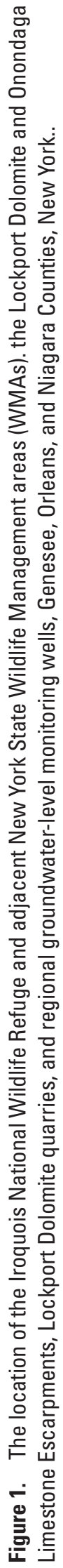




\section{Data Collection}

During the 2-year field study of the Refuge, various types of data were collected to assess the water resources. Meteorological data were supplied by the Refuge weather station located at the headquarters building. Soil, geologic, and hydrogeologic data were determined from (1) existing reports, (2) four bedrock wells drilled within the Refuge, and (3) 17 continuous-water-level monitors use to determine seasonal water-level fluctuations in the unconsolidated and bedrock aquifers underlying the Refuge. Water-quality samples were collected from streams and existing and newlydrilled test wells across the Refuge. A continuous streamgage was established on Oak Orchard Creek at Harrison Road (station 04220045; fig. 2) just north of the Refuge to monitor flow from the Refuge and to relate flow to precipitation and management activities in the Refuge.

\section{Geologic Data}

Data were collected to determine the types and extent of glacial deposits present in the Refuge and surrounding region. Records from drinking-water wells, test holes for bridges and roadways, and test wells drilled by the Refuge and the USGS provided information on the glacial deposits and the underlying bedrock.

\section{Well Inventory and Test Drilling}

Data from the Water-Well Reporting Program of the NYSDEC-Division of Water, (2000-2009) were retrieved for Genesee and Orleans Counties. Individual well records were reviewed, and 11 wells located near the Refuge provided information on the depth to bedrock, types of unconsolidated deposits and bedrock, estimated water yield from wells (gallons per minute), and general water quality (rated "good" to "poor" by the well driller). Records of wells drilled before the creation of the Refuge were not available as these wells were drilled prior to the Water-Well Reporting Program, which began in 2000, and the Refuge did not have any historic well data on file.

Four deep test holes were drilled on the Refuge for this study to further characterize the nature of the bedrock and the regional character of the groundwater-flow system within the bedrock of the Lockport Group dolomites. Three of the four test holes were drilled into the upper Rochester Shale to determine the regional dip of the bedrock, as well as the changes in groundwater quality with depth. A fourth test hole was drilled with the assistance of the Friends of the Iroquois National Wildlife Refuge, but due to limited funding, the hole was drilled only into the middle of the Lockport Dolomite sequence.

Unconsolidated deposits were characterized by inspecting the drill cuttings as the hole advanced into the bedrock. A steel casing was set in the upper bedrock, and the casing driven until refusal. Drilling then continued in bedrock to the desired depth or until the Rochester Shale was penetrated. The bedrock penetrated by each test hole was characterized by (1) inspecting the drill cuttings, (2) testing the quality of water returned to the surface for specific conductance, temperature, and salinity, and (3) borehole geophysical logging once the test holes were completed. This information was used to separate the open bedrock portion of each test hole into two distinct intervals for water-quality and water-level monitoring.

To separate the bedrock portion of each test hole into two monitoring intervals, a shale-packer assembly (fig. 3) was attached to a 2-inch polyvinyl chloride (PVC) pipe and lowered to a designated depth in the well. The 2-inch pipe string was held in place at the top of the well, and the shalepacker assembly was initially backfilled with about 2 feet of sand, and then about 5 feet of bentonite-cement grout was pumped on top of the sand layer to seal and separate the borehole into two monitoring sections. The lower interval of the borehole was accessed through the 2-inch PVC pipe, whereas the upper bedrock interval was accessed in the annular space between the 6-inch dilled hole and the 2-inch PVC casing. The test holes at Oak Orchard Ridge Road (OL37 and OL41), Sour Springs Road (GS286 and GS288), and Dunlap Road (OL42 and OL27) were completed using this method. The test hole at Salt Road (OL38) was not separated because the only source of water for this location came from the upper bedrock and a small lens of sand and gravel at the bedrock surface; the bedrock part of the test well did not yield any measurable water down into the Rochester Shale.

Two additional pairs of wells were installed within the Refuge using a small truck-mounted drilling rig. The wells were drilled to monitor shallow water-level fluctuations because they might be affected by nearby water bodies. One well pair was installed adjacent to Oak Orchard Creek near the former Sour Springs Road bridge over the creek. The first set of wells (GS245 and GS246; fig. 2) was installed at depths of 6.5 feet and 16.0 feet, respectively, and for each casing, a bentonite seal was placed above the 2.5 -foot-long well screen. The second set of wells (OL32 and OL33 on fig. 2) was installed near the Feeder Channel on the west side of the Refuge in Sutton Marsh. The wells were 7.0 feet and 14.5 feet deep, respectively, and each casing had a bentonite seal above the 2.5-foot-long well screen.

\section{Groundwater Level and Streamflow Measurements}

Continuous groundwater-level monitoring was accomplished by using downhole data loggers that recorded water-level fluctuations to a hundredth of a foot (accuracy to the nearest tenth of a foot) on an hourly basis. Data from the loggers were downloaded every 3 to 4 months for processing. Groundwater-level measurements to a hundredth of a foot were made during site visits using an electric tape from a known reference point at the top of each well casing. The reference point was leveled, in most cases, to a stable benchmark located in proximity to the well, although in 




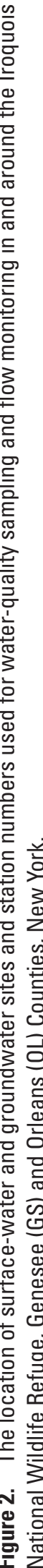




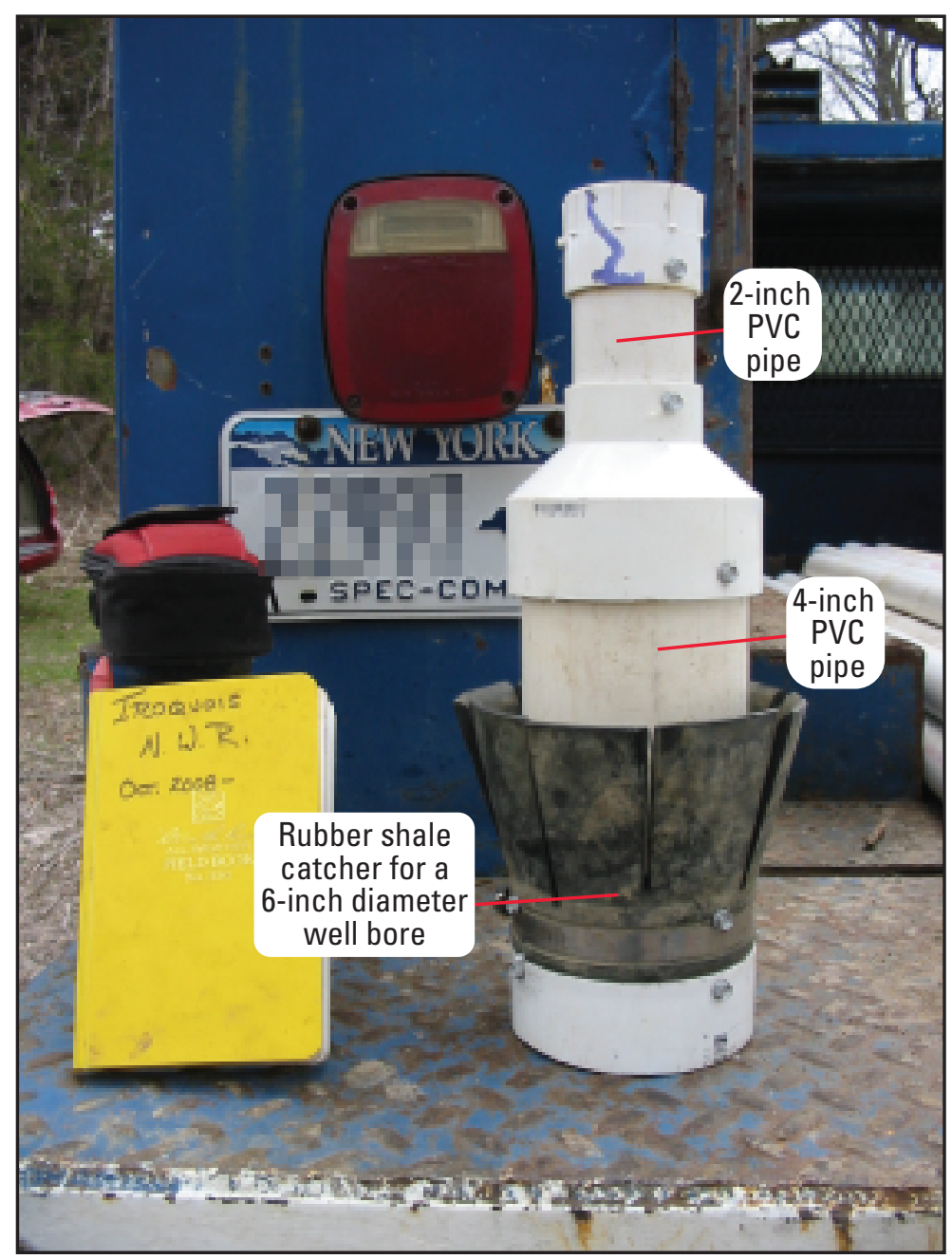

Figure 3. Shale-packer assembly used to separate three Lockport Dolomite test holes into two monitoring intervals in the Lockport Dolomite bedrock, Genesee and Orleans Counties, New York.

(PVC, polyvinyl chloride). 
several cases, the elevation-level surveys were several miles in length. In a few cases, there was no nearby benchmark so a Global Positioning System (GPS) unit was used to determine a local reference elevation. Although measurements from the GPS unit were considered reliable to a hundredth of a foot, the accuracy was again considered to be to the nearest tenth of a foot. The computed local elevation was then converted from the North American Vertical Datum of 1988 (NAVD88) to the National Geodetic Vertical Datum of 1929 (NGVD29) (Refuge datum) to provide the elevation of the remote well sites on the Refuge.

Streamflow measurements were made seasonally along Oak Orchard Creek from November 2008 through November 2010. Several tributary streams to Oak Orchard Creek were measured only during spring runoff in 2009, because most tributary channels to Oak Orchard Creek are usually dry by early summer, with flow returning to them late in the fall or winter. Streamflow-measuring techniques are described by Buchanan and Somers (1982). The seasonal measurements for Oak Orchard Creek were made at three locations: Knowlesville Road on the eastern side of the Refuge (04219997); State Route 63, located approximately in the middle of the Refuge (04219998); and Harrison Road, just north of the Refuge (04220045; fig. 2). The other measurement sites were on Brinningstool Creek entering the Refuge to the southeast (04219979), Tributary 3 at Shelby Road to the northeast (0421999720), Schoolhouse Marsh Tributary to the north (04219999), and Tributary 2 at Roberts Road to the south (0421999750; fig. 2; table 1).

A continuous streamgage was installed just north of the Refuge on Oak Orchard Creek at Harrison Road, near Shelby, N.Y., on December 3, 2008. The gaging equipment records nearly-continuous stage (water level) data from a pressuresensor located in the creek at 15-minute intervals on an electronic data logger. These data were manually downloaded every 2 months for analysis and posted on the USGS New York Water Science Center's Web page (http://ny.water.usgs. gov/). Streamflow measurements were collected on a routine basis to develop a stage-discharge relation. Using the stage data collected at the site and the stage-discharge relation, the continuous record of stage is converted to a continuous record of discharge. More detailed information about the USGS stream-gaging program is presented by Blanchard (2007).

Water levels at the Harrison Road gage are normally controlled by a bedrock riffle under the bridge at lower flows and by the downstream channel at mid-to-high flows. During the first year of streamgage operation, an unknown condition downstream apparently created substantial backwater; a debris jam or beaver dam located some distance downstream is suspected. This condition cleared after high flows the following spring. On May 15, 2009, the stage of Oak Orchard Creek dropped below that of the pressure sensor. This condition was not discovered until the next scheduled site visit on June 11, 2009. At that time, the pipe housing the sensor was extended lower into the water. Therefore, there is a gap in the continuous record between the May 15 and June 11, 2009, however, most of the streamflow measurements collected at Harrison Road provided a definitive stage-discharge relation, and the gage record is rated "good," that is, 95 percent of the daily streamflow values are within 10 percent of the stagedischarge relation (Rantz, 1982).

\section{Water-Quality Sampling and Analyses}

Water quality was determined across the Refuge for both surface water and groundwater (appendix 1). Surface-waterquality samples were collected seasonally in Oak Orchard Creek between November 2008 and September 2010, and a set of spring runoff samples was collected from several tributary streams in late March 2009. The samples were analyzed for inorganic constituents and nutrients by the USGS National Water Quality Laboratory (NWQL) in Denver, Colorado. In addition, the last three Oak Orchard Creek sample sets in 2010 were analyzed for trace metals. Field measurements of $\mathrm{pH}$, specific conductance, salinity, temperature, and dissolved oxygen were made for each sample. The stream samples were collected using the equal-width-increment method and processed following methods described in the USGS National Field Manual for the Collection of Water-Quality Data (U.S. Geological Survey, variously dated).

Groundwater-quality samples collected from eight wells across the Refuge during 2009-10 were analyzed for nutrients, inorganic constituents, and trace metals. Three samples were collected from the lower Lockport Dolomite section of the Dunlap Road (OL42), Sour Springs Road (GS286), and Oak Orchard Ridge Road (OL37) wells. Six samples were collected from the upper Lockport Dolomite section of the Dunlap Road (OL27), Sour Springs Road (GS288), Salt Road (OL38), and Oak Orchard Ridge Road (OL41) wells and from two production wells at the Iroquois Job Corps Center (OL39 and OL40). Samples also were collected from the sand and gravel zone on top of bedrock at the Sour Springs Road (GS244) and Refuge office wells (GS287). Water from all these wells was pumped through a 2-inch submersible pump, and the sample was collected after several (at least three) casing-volumes of water were removed and field measurements of specific conductance, salinity, and temperature had stabilized.

Six springs were sampled in the Refuge in 2009 and 2010 - a sulfur-water spring along Oak Orchard Creek at the Dunlap Road Bridge (OL43), a fresh-water spring discharging from the Lockport Dolomite near the intersection of Dunlap and Shelby Roads (OL44), and four of the Oak Orchard Acid Springs located near Oak Orchard Creek on the eastern side of the Refuge (GS290, GS291, GS292, and GS293). The spring samples were collected from either the discharge of the spring or, in the case of the Acid Springs, from each spring pool, at a depth of about 6 inches below the water surface. Field measurements of $\mathrm{pH}$, specific conductance, salinity, temperature, and dissolved oxygen were made at all the springs. (At the request of the Refuge, the location of the Oak Orchard Acid Springs is not shown in this report because of the Springs' remote location and historic importance.) 
Table 1. Surface-water and groundwater sampling sites and station numbers at the Iroquois National Wildlife Refuge, Genesee and Orleans Counties, New York.

\begin{tabular}{|c|c|c|c|}
\hline \multicolumn{4}{|c|}{ Surface water sites } \\
\hline Station number & & \multicolumn{2}{|l|}{ Station name } \\
\hline 04219979 & & \multicolumn{2}{|c|}{ Brinningstool Creek at Wheatville, NY } \\
\hline 042199H97 & & \multicolumn{2}{|c|}{ Oak Orchard Creek near Wheatville, NY (Knowlesville Road) } \\
\hline 0421999720 & & \multicolumn{2}{|c|}{ Oak Orchard Creek Tributary near East Shelby, NY } \\
\hline 0421999750 & & \multicolumn{2}{|c|}{ Oak Orchard Creek Tributary at Roberts Road near Alabama, NY } \\
\hline 04219998 & & \multicolumn{2}{|c|}{ Oak Orchard Creek at SR63 near West Shelby, NY (NYS Route 63) } \\
\hline 04219999 & & \multicolumn{2}{|c|}{ Oak Orchard Creek Tributary near Shelby, NY } \\
\hline 04220045 & & \multicolumn{2}{|c|}{ Oak Orchard Creek near Shelby, NY (Harrison Road) } \\
\hline \multicolumn{4}{|c|}{ Groundwater sites - wells } \\
\hline County number & Site number & Site location name & Geologic unit monitored \\
\hline GS244 & 430721078221401 & Sour Springs Road & Lacustrine sand and gravel \\
\hline GS245 & 430732078221001 & Oak Orchard Creek well pair & Lower unconsolidated sediment \\
\hline GS246 & 430732078221002 & Oak Orchard Creek well pair & Upper unconsolidated sediment \\
\hline GS286 & 430720078221501 & Sour Springs Road & Lower Lockport Dolomite \\
\hline GS287 & 430643078241501 & Refuge Office well & Lacustrine sand and gravel \\
\hline GS288 & 430720078221502 & Sour Springs Road & Upper Lockport Dolomite \\
\hline GS294 & 430635078345501 & Casey Road & Lacustrine sand and gravel \\
\hline OL25 & 430931078214201 & Proposed quarry & Lockport Dolomite \\
\hline OL27 & 430924078241301 & Dunlap Road & Upper Lockport Dolomite \\
\hline OL28 & 430938078220601 & Fletcher Chapel Road & Lacustrine sand and gravel \\
\hline OL29 & 430943078222301 & Fletcher Chapel Road & Lockport Dolomite \\
\hline OL30 & 430954078205301 & Fletcher Chapel Road & Unconsolidated sediment - dug well \\
\hline OL31 & 430957078203801 & Fletcher Chapel Road & Lacustrine sand and gravel \\
\hline OL32 & 430758078250201 & Feeder Canal well pair & Lower unconsolidated sediment \\
\hline OL33 & 430758078250202 & Feeder Canal well pair & Upper unconsolidated sediment \\
\hline OL37 & 430852078221101 & Oak Orchard Ridge Road & Lower Lockport Dolomite \\
\hline OL38 & 430755078271301 & Salt Road & Upper Lockport Dolomite \\
\hline OL39 & 430826078213701 & Job Corps Center & Upper Lockport Dolomite \\
\hline OL40 & 430828078214101 & Job Corps Center & Upper Lockport Dolomite \\
\hline OL41 & 430852078221102 & Oak Orchard Ridge Road & Upper Lockport Dolomite \\
\hline OL42 & 430924078241302 & Dunlap Road & Lower Lockport Dolomite \\
\hline \multicolumn{4}{|c|}{ Groundwater - springs } \\
\hline County number & Site name & Site location name & Geologic unit monitored \\
\hline GS290 & Spriing \#1 & Oak Orchard Acid Springs & Lacustrine sediments \\
\hline GS291 & Spriing \#2 & Oak Orchard Acid Springs & Lacustrine sediments \\
\hline GS292 & Spriing \#3 & Oak Orchard Acid Springs & Lacustrine sediments \\
\hline GS293 & Spriing \#4 & Oak Orchard Acid Springs & Lacustrine sediments \\
\hline OL43 & 430933078243001 & Sulfur Spring & Lacustrine sediments \\
\hline OL44 & 430938078243001 & Fresh water Spring & Upper Lockport Dolomite \\
\hline
\end{tabular}




\section{Geology}

The bedrock in this part of western New York includes Upper Silurian (Lockport Dolomite) to Middle Devonian (Onondaga Limestone) strata that are roughly 400 million to 350 million years old and comprised mostly of shale between two units of carbonate bedrock. The stratigraphic column for western New York showing former and current nomenclature, specifically the units between the Rochester Shale and the Lockport Dolomite, is presented in figure 4 . The bedrock sequence, originally laid down in horizontal beds in a shallow inland sea, has been modified by plate tectonics and other geologic processes, and now these bedrock units gently dip to the south-southeast at about 40 to 50 feet per mile. Repeated glacial ice advances and retreats have resulted in modification to the bedrock surface and variable thicknesses and types of glacial and post-glacial sediments that cover most of the region.

\section{Bedrock Geology}

The surficial bedrock in the vicinity of the Refuge is Vernon Shale and Lockport Group of Silurian age. The bedrock units generally lie in east-west bands with the Lockport Group lying in the northern and central part of the study area and with the Vernon Shale lying just south of the Refuge, with Onondaga Limestone of Devonian age cropping out several miles further to the south. The nomenclature for the description of Lockport and Clinton Groups used in this report is that of Brett and others (1995).

The deepest unit drilled during this study is the Clinton Group, and just the upper part of the Burleigh Hill Member of the Rochester Shale was penetrated (fig. 4). Overlying the Rochester Shale is the DeCew Dolomite, which is also part of the Clinton Group. Above the Clinton Group is the Lockport Group, which underlies most of the Refuge. The Lockport Group consists of about 160 feet of massive to mediumbedded argillaceous (shaley) dolomite with minor amounts of dolomitic limestone and shale (Brett and others, 1995, p. 45). The Lockport Group is subdivided into four formations, starting from the bottom: the Gasport Dolomite, the Goat Island Dolomite, the Eramosa Dolomite, and the Guelph Dolomite. From the bedrock cuttings recovered during the drilling of the USGS test holes and the subsequent borehole geophysical testing of each test hole, the Goat Island and Eramosa units were present in all test holes, whereas the lower part of the Guelph Dolomite through the remaining Lockport sequence is present in the Sour Springs Road test hole.

Overlying the Lockport Group is the Upper Silurian Salina Group, which is comprised of the Vernon Shale, the Syracuse Shale, and the Camillus Shale. Along the southern boundary of the Refuge, the Vernon Shale unit is likely present, whereas farther to the south, the upper units (Syracuse and Camillus) begin to crop out near land surface. Overlying the Salina Group, the Akron Dolomite of the Salina Group generally crops out south of Oakfield, N.Y. (fig. 1). Finally, south of Oakfield, N.Y., the Onondaga Limestone of Middle Devonian age is present and forms a subtle escarpment in the area. There is an unconformity (erosional surface) typical of this part of New York State, whereby Lower Devonian-aged bedrock is not present between the Salina Group and the overlying Onondaga Limestone.

\section{Glacial Geology}

New York was repeatedly covered by continental ice during the past 2.5 million years (Teller, 1987). The advance of major ice sheets scoured away soil and vegetation then began to erode the underlying bedrock. The results of this erosion left the glacial ice mass heavily loaded with sediment that was eventually deposited as glacial "drift" as the ice mass melted and receded. The most recent glacial period (Wisconsinan) reached its glacial maximum about 21,000 years ago (Michelson and others, 1983; Stone, 1995) and covered most of New York with ice.

During the last recession of Wisconsinan glacial ice in the western part of New York, several "short-term" ice readvances left additional glacial deposits, such as small, local, recessional moraines, some of which contain (or are part of) beach ridges that formed in shallow proglacial lakes. Between these ridges, lacustrine silt and clay settled out of the turbid glacial waters to the lake bottom.

Successive proglacial lakes developed in the Lake Erie basin, as much of the glacial waters drained to the west and the Mississippi River. As the glacial ice continued to melt back to the north, eastward drainage developed into Glacial Lake Tonawanda (Cadwell, 1988), which discharged to Glacial Lake Iroquois (a progenitor of Lake Ontario). Glacial Lake Tonawanda (fig. 5) developed in a glacially-excavated trough within the erodible Salina Group, between the Onondaga Limestone and Lockport Dolomite Escarpments.

Initially Glacial Lake Tonawanda drained through an outlet at Holley, N.Y. (fig. 5), but the land surface slowly rose in response to the ice front receding to the north. Therefore, the Holley outlet was abandoned as the surface area of the lake shrank back to the west. The next lake outlet formed at Medina, N.Y., with a secondary channel located at presentday Middleport, N.Y. (fig. 5). The Medina outlet channel is the present-day location of Oak Orchard Creek where it drains north over the Lockport Escarpment. Continued glacial recession and land-surface rebound further reduced the elevation and extent of Glacial Lake Tonawanda, as three additional outlets for the lake - at present day Gasport, N.Y., then Lockport, N.Y., and finally at Lewiston, N.Y.- developed toward the west. The lake then disappeared entirely as Lake Erie drained through the Niagara River gorge, to a lower level of Glacial Lake Iroquois, which subsequently became Lake Ontario.

Wetland areas in the study area, including the Oak Orchard Creek wetland and farther to the south and west the 
Revised stratigraphic nomenclature for the Lockport and Clinton Groups in the Niagara region of western New York by Brett and others (1995)

Former stratigraphic nomenclature for the Clinton Group in the Niagara region of western New York by Zenger (1962)

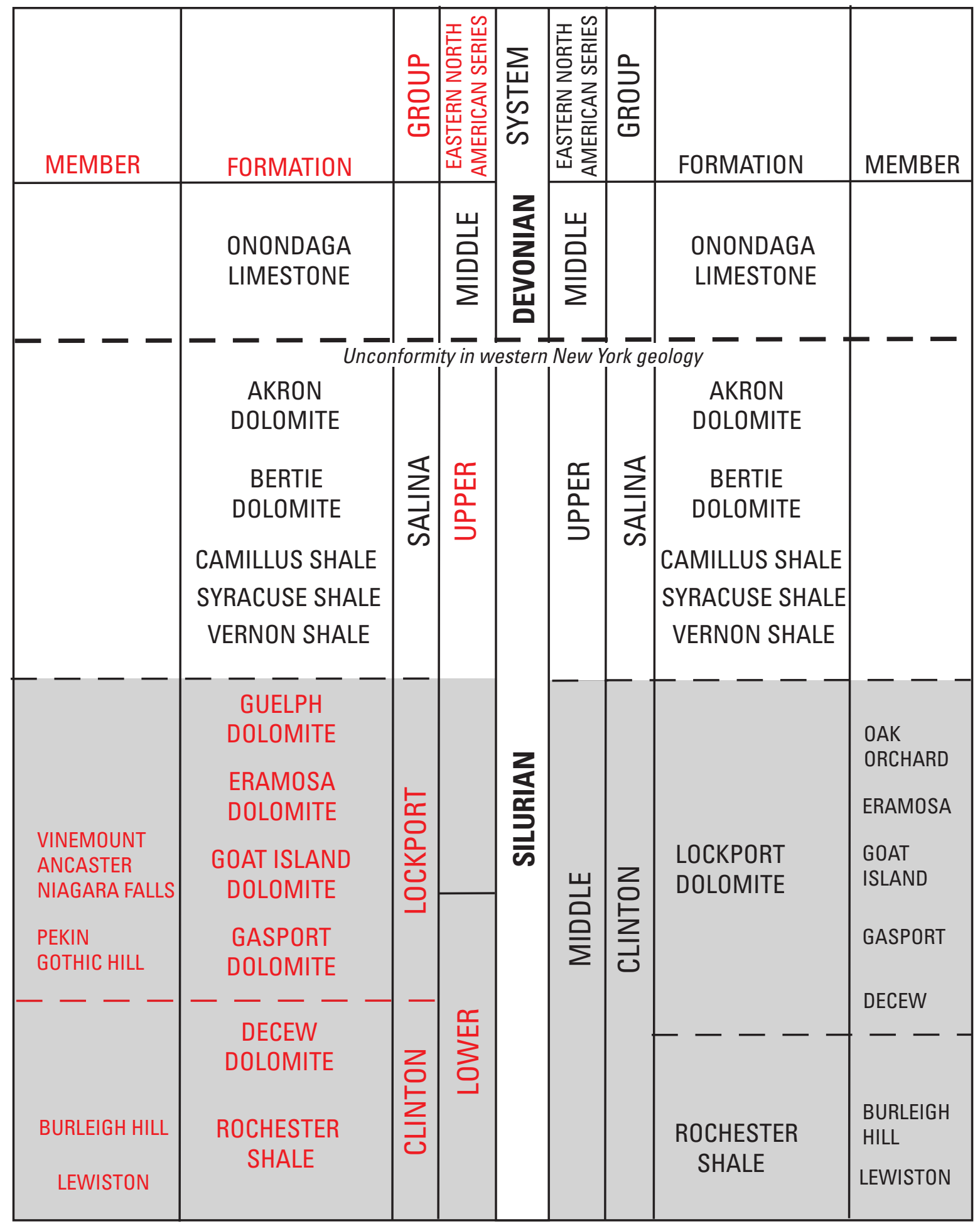

Figure 4. Stratigraphic columns for the western part of New York State showing the summary of geologic units near the Iroquois National Wildlife Refuge, Genesee and Orleans Counties, New York. Stratigraphic nomenclature for the Clinton Group in the Niagara region of Western New York is by Zenger (1962). Changes in nomenclature (in red) for the Clinton and Lockport Groups are by Brett and others, (1995). 


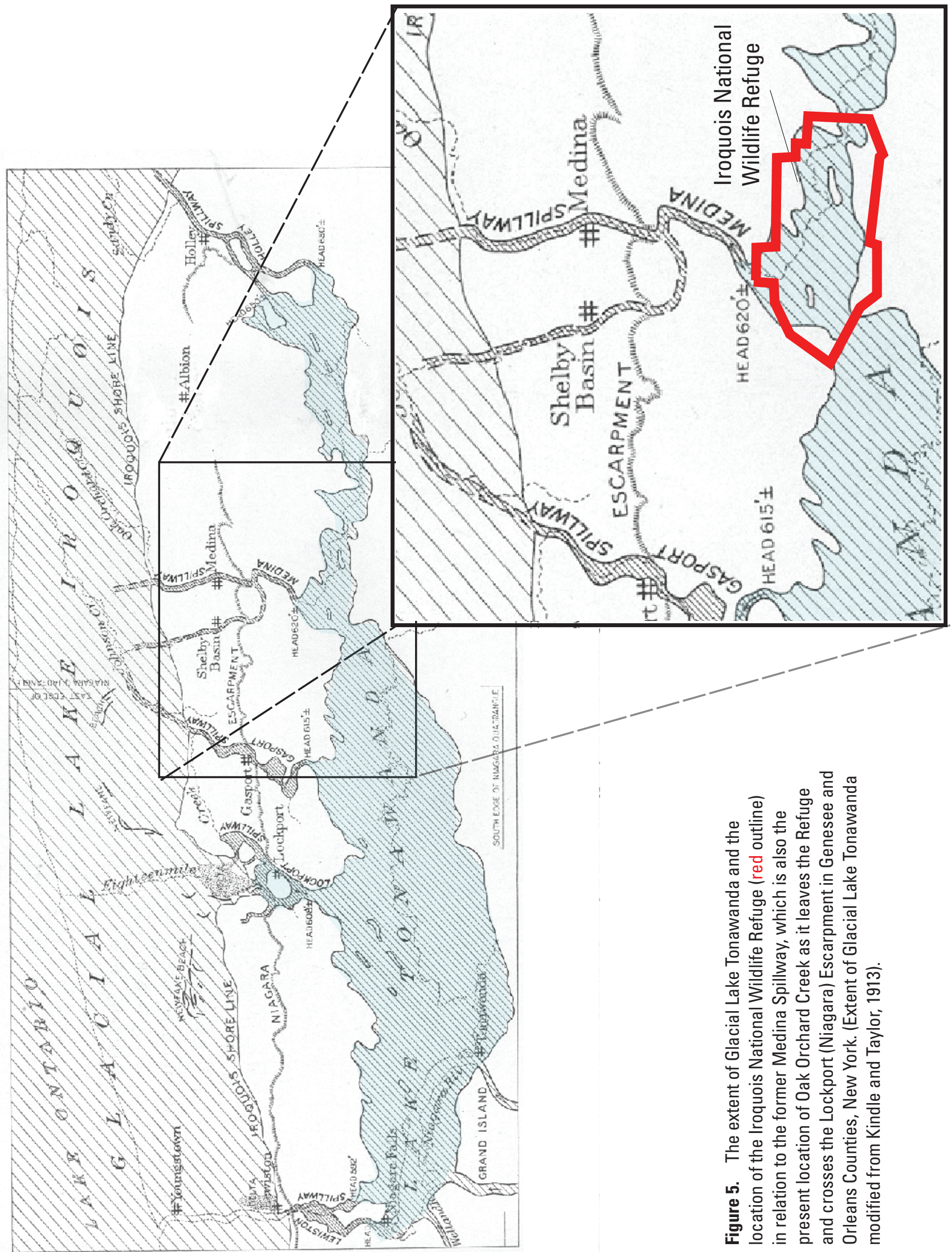


Tonawanda Creek wetland, are underlain by silt and clay deposited in Glacial Lake Tonawanda. Upland areas are former beach ridges and small moraines and are now generally forested or support modest residential development; the intermediate lands are gently sloping and used primarily for agricultural purposes.

\section{Water Resources}

The surface-water resources of the Refuge include Oak Orchard Creek, its tributaries, and the adjacent wetlands that are managed by the Refuge and NYSDEC. The groundwater resources include the unconsolidated and bedrock aquifers. Understanding the interconnection within and between the surface-water and groundwater flow systems is critical to the management of the Refuge and the development of their 15-year conservation plan.

\section{Surface-Water Flow System}

The surface-water flow system of the Oak Orchard Creek, its tributaries, and wetlands is primarily driven by precipitation and surface runoff, and to a lesser extent, groundwater discharge as baseflow to the streams and wetlands. Depending on antecedent water levels within and upgradient from the Refuge, the New York State Oak Orchard WMA, and the agricultural areas farther up in the watershed, the amount of water flowing into and out of the Refuge can vary based on the management of water levels in the State and Federal wetland-management units and the upgradient agricultural areas. Depending on management activities in the Refuge and farther upstream, a large amount of water flowing in Oak Orchard Creek can be diverted into or out of these wetlands, altering the amount and timing of flow entering and leaving the Refuge.

During the spring runoff, flow in Oak Orchard Creek and its tributaries is derived from snowmelt runoff, early spring rainfall, and a modest amount of shallow groundwater discharge from scattered upland sand and gravel deposits. During the spring 2009 runoff period, flow at the three Oak Orchard Creek sites averaged about 800 cubic feet per second $\left(\mathrm{ft}^{3} / \mathrm{s}\right)$ or about 7 cubic feet per second per square mile $\left(\mathrm{ft}^{3} / \mathrm{s} / \mathrm{mi}^{2}\right)$ of the watershed.

Water-quality data (appendix 1) substantiate the composition of water in Oak Orchard Creek as both surface water and groundwater. The quality of water during the spring, as measured by the carbonate-to-sulfate ratio, indicated a predominant carbonate excess (more carbonate than sulfate) in the runoff that most likely comes from additional groundwater discharge from the Onondaga Limestone Escarpment, which has more carbonate than water flowing from the Salina Group Shale bedrock unit.

Following spring runoff and the establishment of wetland management-pool levels, water levels within the wetlands remain fairly steady until the wetland vegetation breaks dormancy and the evapo-transpiration (ET) process begins. Once air temperatures rise and wetland plants are fully leafedout, the rate of ET will usually be greater than the amount of precipitation that falls in this part of New York State. Subsequent wetland water levels may fall slowly, especially if a wetland is not hydraulically connected to Oak Orchard Creek or a tributary stream. Furthermore, groundwater discharge (water moving slowly upwards through the finegrained lacustrine sediments into the overlying organic soils) is quite slow and will not keep up with the rate of ET.

During the summer, flow in Oak Orchard Creek and its tributaries decrease because ET increases and precipitation decreases. During this period, the wetlands have reduced hydrologic interaction with Oak Orchard Creek as flow along the entire length of the Creek within the Refuge is generally confined within the banks of the creek and does not interact with adjoining wetlands. On July 19, 2010, the average flow measured in Oak Orchard Creek at the three creek sites (Knowlesville Road in the east, Route 63 in the central, and Harrison Road in the northwest) was about $20.5 \mathrm{ft}^{3} / \mathrm{s}$ or about $0.16 \mathrm{ft} 3 / \mathrm{s} / \mathrm{mi}^{2}$, or about 2 percent of the peak flow measured in spring 2009. Correspondingly, on September 17, 2010, the average flow in Oak Orchard Creek at the three sites was about $15 \mathrm{ft}^{3} / \mathrm{s}$ or about $0.12 \mathrm{ft}^{3} / \mathrm{s} / \mathrm{mi}^{2}$. The very low rate of flow measured on these 2 days across the Refuge indicates that groundwater discharge to the surface-water system within the Refuge is low and is likely lost through wetland ET. When looking at the carbonate-to-sulfate ratio in Oak Orchard Creek during low-flow conditions, sulfate enrichment over calcium is observed (opposite of the spring ratio), which indicates that the low flow in Oak Orchard Creek is more likely derived from small amounts of seepage from adjacent wetland areas and even less groundwater discharge from the underlying Salina Group and Lockport Dolomite bedrock.

The transition to cooler fall temperatures, decreased ET, and increased precipitation causes greater surface-water flow and groundwater discharge, which fills the channel of Oak Orchard Creek and its tributaries and allows the adjacent wetlands to again interact with the creek. Because groundwater levels are lowest at this time of the year, the Oak Orchard Creek system is dominated by surface-water runoff and precipitation that falls directly on the watershed and wetland areas. Discharge of groundwater to the surface-waterflow system, be it to the tributaries or the main stem of Oak Orchard Creek, continues to be small. The degree of wetland/ stream interaction depends on how the wetland units are managed and the variability of seasonal climate conditions.

\section{Groundwater-Flow System}

The groundwater-flow system in and around the Refuge is comprised of a glacial, unconsolidated aquifer, underlain by a bedrock aquifer. Within the glacial sediments, there are lenses of sand and gravel that sit directly over bedrock, 
whereas in nearby locations, the sand and gravel is absent and only fine-grained sediments (clays, silts, and silty sands) are present. On top of the fine-grained sediments, some of the beach ridges are covered by permeable sand and gravel deposits that may be till-cored moraines. Each type and combination of glacial sediments mentioned above has various hydraulic characteristics that contribute to the overall volume, timing, and direction of groundwater flow within the regional aquifer system (fig. 6). Also, the mineralogy of the deposits through which the groundwater moves and the interaction with various land uses (wetlands to agriculture to forest) can affect the quality of water.

Groundwater levels were determined during this study from wells within and near to the Refuge and from waterlevel data derived from the NYSDEC Water Well Reporting Program for areas outside the Refuge boundary. These data allowed the development of a regional water-table map for wells in both the unconsolidated and bedrock aquifers (fig. 6); as these data were collected in the two aquifers at various times during the past several decades, this map can only be considered a generalized depiction of the regional water-table configuration. The regional map indicates that water levels are highest south and east of the Refuge and become progressively lower to the north and west. This pattern follows, for the most part, the elevation change from the Onondaga Limestone Escarpment to the south (at an elevation of approximately 900 feet) to the Lockport Dolomite Escarpment north of the Refuge (at an elevation of approximately 625 feet). Groundwater flow appears to follow the general trend of the east-to-west dipping bedrock trough between the two carbonate escarpments (fig. 7) but groundwater-level information for areas farther to the west is not available to determine whether there are possible outlets for groundwater flow northward toward the escarpment or southwestward toward Tonawanda Creek or a combination of the two.

\section{Unconsolidated Aquifer}

The unconsolidated sediments within the Refuge form aquifers that are unconfined to semiconfined. Data collected from two very-shallow well pairs - one along Oak Orchard Creek (GS245 and GS246) and the other along the Feeder Channel (OL32 and OL33; fig. 2) -indicate a small, upward gradient, approximately a tenth of a foot difference in water level (hydraulic head) between the deeper and shallower wells, with a distance of about 6 feet between the well screens (appendix 2, hydrographs P and Q). Along Sour Springs Road, south of Oak Orchard Creek, the water-level elevation in a homeowner-well finished in a lens of sand and gravel at the bedrock surface (GS244) is higher than the waterlevel elevation of water in the shallow well pair along Oak Orchard Creek (GS245 and GS246). These different water levels indicate a 4-foot upward gradient from the sand and gravel lens deposit overlying bedrock, up through the finergrained unconsolidated sediments in which the Oak Orchard Creek well pair are finished, over a distance of about 48 feet between the deeper and shallower wells. A slight upward gradient is present within the very-shallow well pair (appendix 2 , hydrograph $\mathrm{G}$ for the sand and gravel well, hydrograph $\mathrm{N}$ for the shallow well, and hydrograph $\mathrm{O}$ for the deep lacustrine well).

\section{Bedrock Aquifer}

The Salt Road well (OL38) on the west side of the Refuge did not yield measurable water from just below the bedrock surface down to the top of the Rochester Shale. It is not uncommon to drill a "dry hole" in the bedrock of upstate New York, although it is more common in shale than in carbonate rock, which typically has water-bearing bedding planes. Water entering the Salt Road well comes from the weathered and fractured bedrock surface and a small sand and gravel lens lying on top of the bedrock. Water that entered the well at the base of steel casing (top of bedrock was at a depth of 70 feet) at the time of drilling filled the well over several hours, coming to equilibrium at about 30 feet below land surface. The water levels at Salt Road (OL38; appendix 2, hydrograph C) from November 2008 to October 2010 fluctuated in a manner similar to that of other bedrock and unconsolidated wells across the region.

Water levels in the bedrock wells finished with upper and lower bedrock monitoring zones that indicate two different water-level relations. Each well pair - Sour Springs Road (GS245 lower bedrock and GS246 upper bedrock), Oak Orchard Ridge Road (OL37 lower bedrock and OL41 upper bedrock), and Dunlap Road (OL42 lower bedrock and OL27 upper bedrock) - was separated into two monitoring zones on the basis of the location of water-bearing zones detected by borehole geophysics at each well (appendix 3, figs. A through D). In the Dunlap Road and Sour Springs Road well pairs, the gradient between the lower bedrock zone and upper bedrock zone indicated upward movement of water in the bedrock because the water level in the lower zone was consistently higher than that in the upper zone. The head difference was about 4 feet, on average, at the Dunlap Road wells during the period of measurement and about 2 feet, on average, at the Sour Springs Road wells. The well pair at Oak Orchard Ridge Road had the opposite hydraulic head gradient than the other well pairs - the water level in the upper zone was, on average, about 4 feet higher than the water level in the lower zone, indicating a downward gradient for groundwater flow. The reason for the downward hydraulic-head gradient at Oak Orchard Ridge Road could be (1) the well was not drilled deep enough and (or) the packer was not placed deep enough to isolate a lower bedding plane with a higher head, (2) the open test holes for the proposed quarry just north of the Oak Orchard Ridge Road well could be locally affecting the head relation in the Oak Orchard Ridge Road wells, or (3) the production wells at the Iroquois Job Corps Center (OL39 and OL40; fig. 2) might be affecting the hydraulic-head relation. To eliminate one of the possibilities, the two zones at Oak Orchard Ridge Road wells were closely monitored during the 


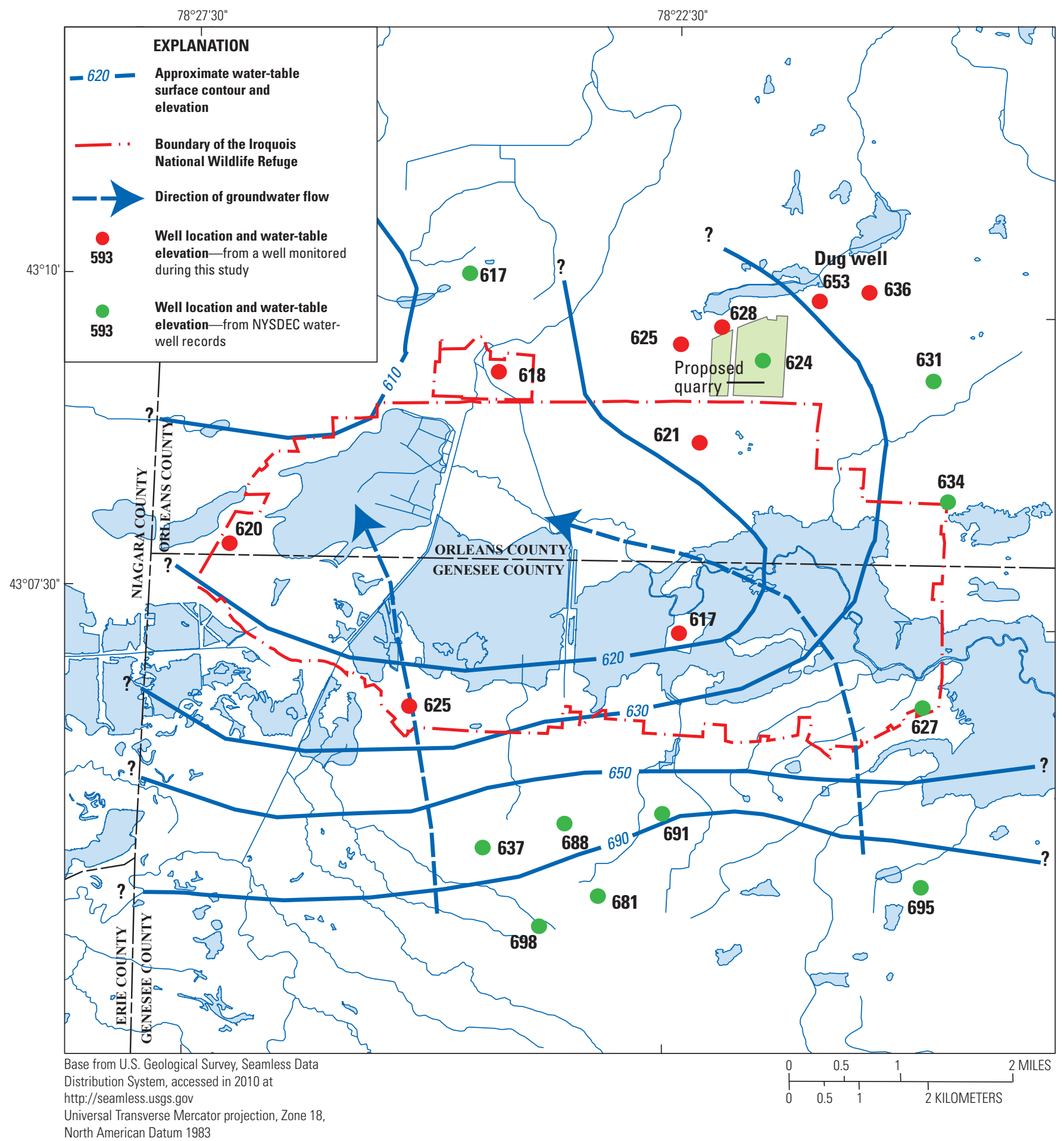

Figure 6. Approximate water table and the general direction of groundwater flow in the unconsolidated and bedrock aquifers in the vicinity of the Iroquois National Wildlife Refuge, Genesee and Orleans Counties, New York. Elevations are in feet. (NYSDEC, New York State Department of Environmental Conservation). 


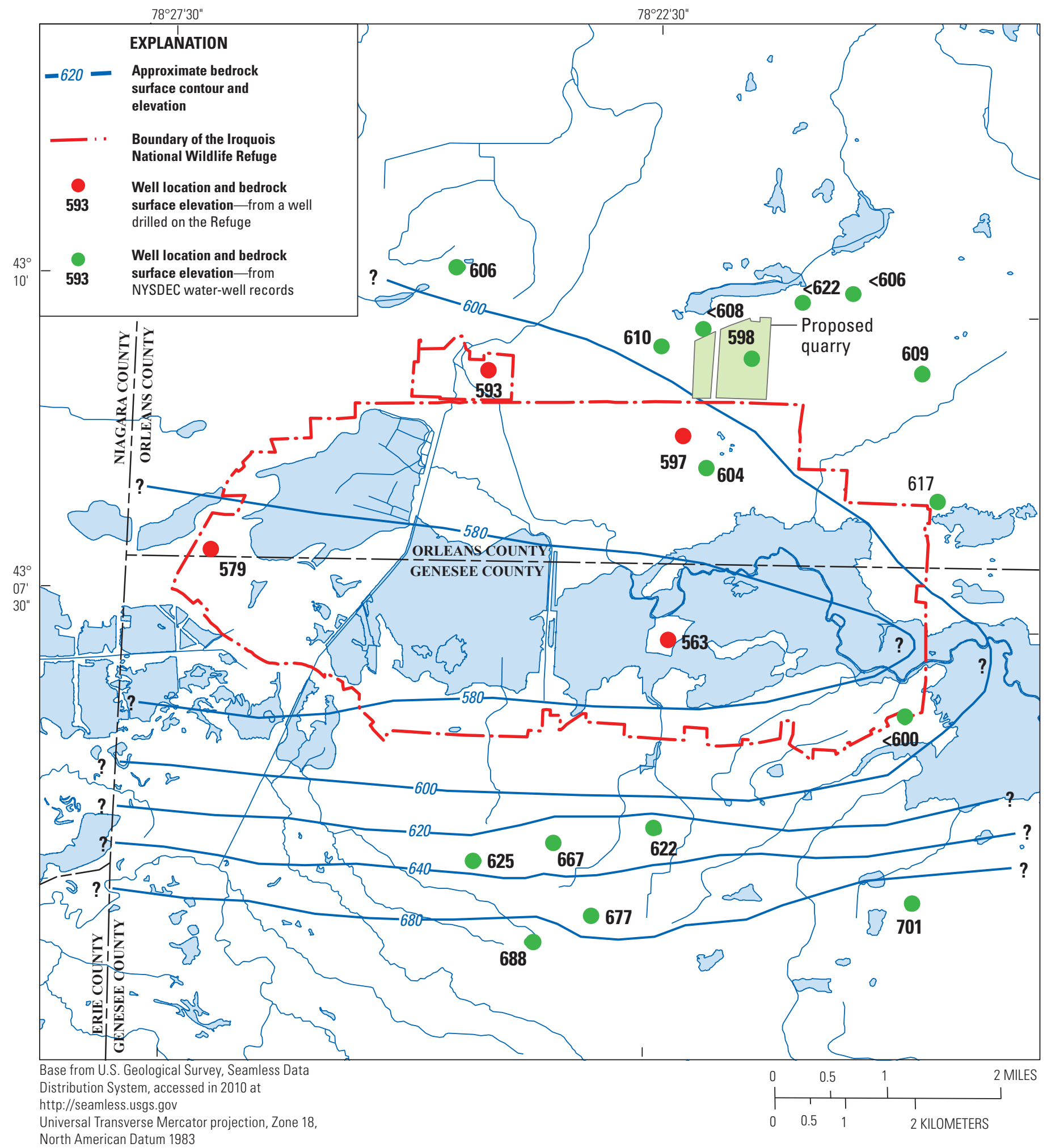

Figure 7. Approximate bedrock-surface contour and elevation in the vicinity of the Iroquois National Wildlife Refuge, Genesee and Orleans Counties, New York. Elevations are in feet. (NYSDEC, New York State Department of Environmental Conservation). 
winter and summer vacation periods at the Job Corps Center, when water use is greatly reduced. No perceptible change was noted in the Oak Orchard Ridge Road wells monitoring zones and therefore, one or both of the two remaining theories may indicate the conditions affecting the head gradient at this location.

\section{Well Hydrographs}

Water-level fluctuations in 17 wells, including unused homeowner wells were monitored throughout the Refuge area (appendix 2). One dug well (OL30) north of the Refuge on Fletcher Chapel Road was also monitored (appendix 2, hydrograph A). The annual water-level fluctuation was almost 20 feet. The well was responsive to spring recharge and showed a slow water-level decline during the summer; water levels for this well during summer 2010 were not collected due to equipment malfunction.

Water-level fluctuations varied depending on the aquifer monitored and the topographic position of the well. In four wells that tap an apparently discontinuous layer of sand and gravel that overlies bedrock (GS244, GS294, OL28, and OL31), water-level fluctuations during the 2-year monitoring period ranged from 3 to 8 feet. In the four wells finished in the upper Lockport Dolomite bedrock (GS288, OL41, OL27, and OL38), water-level fluctuations ranged from 3 to 6 feet, whereas in three wells finished in the lower Lockport Dolomite bedrock (GS286, OL37, and OL42), water-level fluctuations ranged from 4 to 8 feet. The amount of fluctuation varied depending on the topographic position of the wells. Those closest to the creek and lowest in land-surface elevation varied the least; those farther from the creek and at higher elevations varied the most over the 2 years of monitoring.

The water levels in two well pairs located along Oak Orchard Creek (GS245 and GS246) and the Feeder Channel (OL32 and OL33) fluctuated by about 4 feet and 1 foot, respectively. The water-level fluctuations for these well pairs reflect the interactions of the well pairs with those in the nearby surface-water body; the water level at the Feeder Channel is generally maintained at a prescribed management level, whereas the water level at Oak Orchard Creek is minimally regulated at the downstream end of the Refuge, several miles away from this second well pair. The shallower well in each pair also fluctuates more, albeit by only an additional 0.5 foot. This was most likely related to the fluctuation in the nearby stream, such as spring flooding of the marsh, which overtopped the land surface at both well sites. These wells indicate that, while the local groundwater gradient is upward in the fine-grained lacustrine soils, the rate of flow is likely small because the rate of change in the upper zone when overwhelmed by the water level of the adjacent water body is not transferred to the lower zone immediately.

The annual pattern of water-level fluctuation in the wells monitored in this study is affected by (1) the topographic position of the well in the Refuge area (land-surface elevation and proximity to the wetlands) and (2) the regional groundwater response to seasonal changes in precipitation and recharge. Wells on the north side of the Refuge (Fletcher Chapel and Dunlap Road areas, fig. 2) that receive water from either the upper bedrock or the sand and gravel just above the bedrock reflect regional water-level fluctuations, especially where the bedrock or sand and gravel lens is close to land surface. Results of a comparison of well hydrographs from Fletcher Chapel and Dunlap Road wells in the northern part of the Refuge with those from a Lockport Dolomite well located about 25 miles to the west of the Refuge (Niagara County well NI869, fig. 1) indicate a regional pattern of fluctuation as opposed to a local pattern (appendix 2, hydrographs D, E, F, and R). Water levels in wells on the southern and western side of the Refuge that have a greater thickness of unconsolidated deposits and are closer in elevation to the wetlands appear to follow a diminished seasonal water-level fluctuation that is not as greatly affected by rapid recharge of surface water to groundwater.

\section{Natural Gas Discharges}

Water-level fluctuation in the lower Lockport Dolomite zone of the Sour Springs Road (GS286) and Oak Orchard Ridge Road (OL37) wells (appendix 2, hydrographs I and $\mathrm{K}$, respectively) are similar to those in their upper Lockport Dolomite companion zones (wells GS288 and OL41, appendix 2, hydrographs $\mathrm{H}$ and $\mathrm{J}$, respectively). However, the lower zones display a greater amount of fluctuation due to the presence of natural gas (methane and hydrogen sulfide) exsolving (coming out of solution) from the water in the lower bedrock zone of these two test holes. The discharge of natural gas makes the water level fluctuate rapidly (making a "boiling" noise in the well) as the natural gas bubbles-up and out of the water column. This discharge causes the well hydrograph to have a "painted" appearance rather than a smooth line as seen in most of the hydrographs in appendix 2 . In contrast, the lower zone of the Dunlap Road (OL42) well (hydrograph M in appendix 2) does not exhibit this "painted" pattern because the Lockport Dolomite in this location is at a higher elevation and does not have a gas discharge; most likely any gas that might have been present has migrated out of the bedrock through bedding-plane and other fractures to the nearby Lockport Dolomite Escarpment. The Salt Road well (OL38, hydrograph C in appendix 2) exhibits an intermittent natural-gas response, as, during drilling, the smell of hydrogen sulfide gas was present, but disappeared quickly as the well filled with water. The hydrograph for the Salt Road well does display periods where the hydrograph has a "painted" appearance, and at times, a low rate of bubbling can be heard in this well. 


\section{Bedrock Aquifer Response at Local Lockport Quarries}

One of the concerns in the long-term planning process for the Refuge is the possible effects of the development of a bedrock quarry along the northern border of the Refuge, east of Sour Springs Road (fig. 2). The quarry may be more than 120 feet deep, and during dewatering operations, which might need to occur year round, large quantities of groundwater (Continental Placer, 2008) of unknown quality, could be discharged to wetlands in the northern part of the Refuge. To assess the possible effects on the Refuge, two nearby Lockport quarries were visited, and discussions with the quarry managers were held in 2009.

Northwest of the Refuge is the Shelby Crushed Stone quarry, and to the northeast is the Barre Stone Products quarry (fig. 1). Both quarries mine the lower extent of the Lockport Dolomite Group; the Gasport and DeCew Formations are mined in the Shelby quarry. Although visits were made to both quarries, only the Shelby Crushed Stone quarry supplied detailed stratigraphic and hydrologic information. The proposed quarry north of the Refuge would be farther south of the other quarries and would intersect more of the Lockport Dolomite Group if mining proceeded there; the Eramosa Dolomite (formerly the lower part of the Oak Orchard Dolomite) and all the Goat Island, Gasport, and DeCew Dolomites (Continental Placer, 2008).

Groundwater inflow to the Shelby and Barre quarries occurs along bedding planes at the quarry walls, generally in the southern half of each quarry. Groundwater-discharge rates seasonally vary from several hundred to several thousand gallons per minute according to the quarry managers. However, there is an unknown amount of water that reenters each quarry through leakage of discharge pipes and channels, and therefore, an accurate assessment of groundwater discharged from these quarries could not be made. Groundwater quality has not been extensively tested at either quarry, but the water flowing from the quarry walls appears to be fresh and probably has a quality similar to that from the Dunlap Road bedrock well because the quarries and the Dunlap Road well are close to the Lockport Dolomite Escarpment. A testhole drilled into the Rochester Shale on the floor of the Shelby quarry yielded sulfate-rich "black water." This type of water quality was found in the Oak Orchard Ridge bedrock well, which is located about a half mile southwest of the proposed quarry. Natural gas (hydrogen sulfide and possibly methane) is seasonally present in both quarries, but only the smell of hydrogen sulfide has been noted at times (methane has no odor), and the amount of gas has not been a concern for the quarry managers.

Water levels are monitored at the Shelby quarry in open bedrock holes near the quarry walls and at several homes distant from the quarry. Homes several hundred feet east and west of the quarry have not lost or noted changes in their water supplies, but homeowners south of the quarry have reported changes in their water supplies; these changes have not been confirmed. Groundwater studies at other Lockport Dolomite quarries report modest decreases in water levels near active Lockport quarries (Gowan, 1988; Continental Placer, 2008). but according NYSDEC, other studies documented that drawdowns have occurred near Lockport Dolomite quarries at distances of as little as 50 feet from a quarry wall to as far as 1,200 feet (D.L. Bimber, New York State Department of Environmental Conservation, written comm., December, 2009). A USGS study in the Niagara Falls area (Miller and Kappel, 1987) noted that the construction and operation of the Niagara Power Project, where major excavations into the Lockport Dolomite occurred, did affect groundwater levels at distances up to one-half mile from the bedrock excavations.

In comparison to the above water-level drawdown assessments in Lockport Dolomite quarries, another USGS study near an Onondaga Limestone quarry (Staubitz and Miller, 1987) noted that groundwater levels experienced greater water-level decline at greater distances from an Onondaga Limestone quarry than those observed in Lockport Dolomite quarries. Groundwater-level fluctuations also differ between Onondaga Limestone and Lockport Dolomite quarries as shown in the annual hydrographs in appendix 2. Groundwater fluctuations in Lockport Dolomite wells (appendix 2, hydrographs H, J, or L) are about half of those in well GS217, which is drilled into the Onondaga Limestone (appendix 2, hydrograph T). The greater range in groundwaterlevel fluctuation reflects a greater degree of permeability and hydraulic connection in the limestone bedrock rather than in dolomite bedrock.

The effects of development of any bedrock quarry and the effects of dewatering the quarry on local water resources will depend on (1) the type of bedrock being quarried, (2) how well developed the groundwater-flow system is within the bedrock sequence, and (3) the relative position of the quarry in the regional groundwater-flow system. In regard to number two above - a well-developed fractured-rock flow system would more likely be present in highly solution-prone limestone bedrock, as compared to less soluble dolomitic bedrock. In relation to number three above - regarding relative position, if a quarry is located relatively high in the regional topography, where groundwater would be flowing away from the quarry, water-level drawdown during dewatering would be less than that for a quarry located in a low-lying area, where groundwater would naturally flow toward the quarry. The quarry at the lower elevation would most likely experience greater groundwater-level decline and a greater volume of water having to be discharged during annual dewatering operations. The proposed quarry site on the north side of the Refuge is located in the (lower elevation) hydrologic position. 


\section{Water Quality}

The quality of water within and below the Refuge depends on the source and the flowpath taken as water moves through the Oak Orchard Creek watershed. Surface water is affected by precipitation and flow through the soils and shallow glacial deposits. Any anthropogenic activity at or below the soil surface can alter the quality of surface water or groundwater as it moves through the wetlands upstream from and within the Refuge. Any interaction with groundwater that discharges to the surface-water system can also affect the surface-water system. Water-quality changes in either the surface-water or groundwater system are dependent on the flowpath taken, be it shallow through the soils and glacial deposits, slightly deeper through the upper Lockport Dolomite bedrock aquifer, or through a deeper bedrock aquifer, such as the Salina Group Shale further to the south.

\section{Surface Water}

Results of the surface-water-quality analyses for Oak Orchard Creek and several of its tributaries within the Refuge are consistent with others for this part of New York. The $\mathrm{pH}$ of surface water is nearly neutral with a median of about 7.2. The specific conductance of the water ranges from 200 to 2,000 microsiemens per centimeter $(\mu \mathrm{S} / \mathrm{cm})$ at 25 degrees Celsius with the smaller tributaries having slightly less conductance. There is a slight downward trend in specific conductance along Oak Orchard Creek as it flows through the Refuge from east to west.

Nutrient concentrations in samples from Oak Orchard Creek were slightly elevated, which is not unusual for a watershed with areas of major agricultural land use above the Refuge (Makarewicz and Lewis, 2009). Concentrations of various forms of phosphorus and nitrogen are somewhat elevated from natural background conditions, but not as elevated as the concentrations in water discharged to Oak Orchard Creek upstream from the Federal and State WMAs (Makarewicz and Lewis, 2009). Inorganic constituent concentrations (metals such as magnesium, lead, iron, and zinc; appendix 1) are somewhat greater than what would be considered background levels in most of New York State, but this condition might be related to the quality of water discharged from bedrock, such as the Lockport Dolomite and Salina Shale units, up through glacial sediments to Oak Orchard Creek.

\section{Groundwater}

Groundwater quality is highly variable in the region surrounding the Refuge. The quality of groundwater south of the Refuge is poor because it interacts with minerals present within the Salina Group that impart a strong sulfur taste and smell to the water and because it interacts with trace metals and halite (sodium chloride). The slow movement of water in shales of the Salina Group causes trace metal concentrations to increase and therefore results in limited availability of potable water (Bill Frey, Frey Well Drilling, April 2009, oral commun.). Any fresh water found in wells is usually found at the shallowest depths and might require some sort of treatment before it can be used for drinking water or other residential uses.

In the central part of the Refuge, roughly east-west along the Genesee-Orleans County line, the quality of water from bedrock does not improve as the depth to bedrock increases; flow from bedrock bedding planes and fractures usually leaches sulfide-bearing minerals into the slow-moving groundwater. Groundwater from the shallower bedrock generally has a mild-to-strong sulfide taste and smell; stronger sulfide concentrations are present at depth. Also at depth are various forms and quantities of natural gas, primarily methane and hydrogen sulfide gas. The presence of ferrous sulfide produces "black water," which is highly corrosive to many metals, stains clothes and skin, and makes water quite difficult to treat in order to make it potable.

Farther to the north where the Lockport Dolomite is at or near land surface, groundwater flows quickly through the bedrock fractures, and the quality and quantity of water improves. This shallow groundwater is generally quite fresh because it is in the active part of the groundwater-flow system. Even though groundwater in the northern part of the Refuge may interact with the sulfide minerals along bedrock fractures, the short contact time that the groundwater has with these minerals produces low concentrations of sulfide in this part of the groundwater system.

The water-quality data collected during this study (appendix 1) are summarized through the use of a Piper or trilinear diagram (Piper, 1944) to determine which samples have similar ionic composition that may reflect a similar source. The Piper diagram for the Refuge data (fig. 8) shows the relative percentages of major cations (calcium, magnesium, and sodium plus potassium) plotted on the lower left triangle and relative percentages of anions (chloride, bicarbonate, and sulfate) plotted on the lower right triangle. These percentages are then projected to the diamond plot above where certain data points may cluster in a common water type or show a mixing trend of different water types. The water-quality samples of the Oak Orchard Acid Springs are clustered in the upper right corner of the diamond as calcium-sulfate dominated water (see a further description of the Acid Springs below). The groundwater from the sand and gravel well (GS244) along Sour Springs Road is a sodium-bicarbonate-type water as seen on the lower part of the diamond plot, whereas the groundwater from the lower Lockport bedrock well (GS286) at Sour Springs Road is a sodium-chloride-type water. Therefore, the quality of water in the two wells differs. The two springs on the northwest side of the Refuge appear to serve as approximate chemical-mixing endpoints for both surface water and groundwater. A spring located in the Lockport Dolomite (OL44) represents a fresh, calcium-bicarbonate-type water discharging directly from the 
EXPLANATION

○ Oak Orchard Creek

- Tributary to Oak Orchard Creek

$\Delta$ Spring (acid) in lake deposits

+ Spring (fresh) in lake deposits

+ Spring (fresh) upper Lockport

$\times$ Well in sand and gravel

$X$ Well in upper Lockport

$\times$ Well in lower Lockport
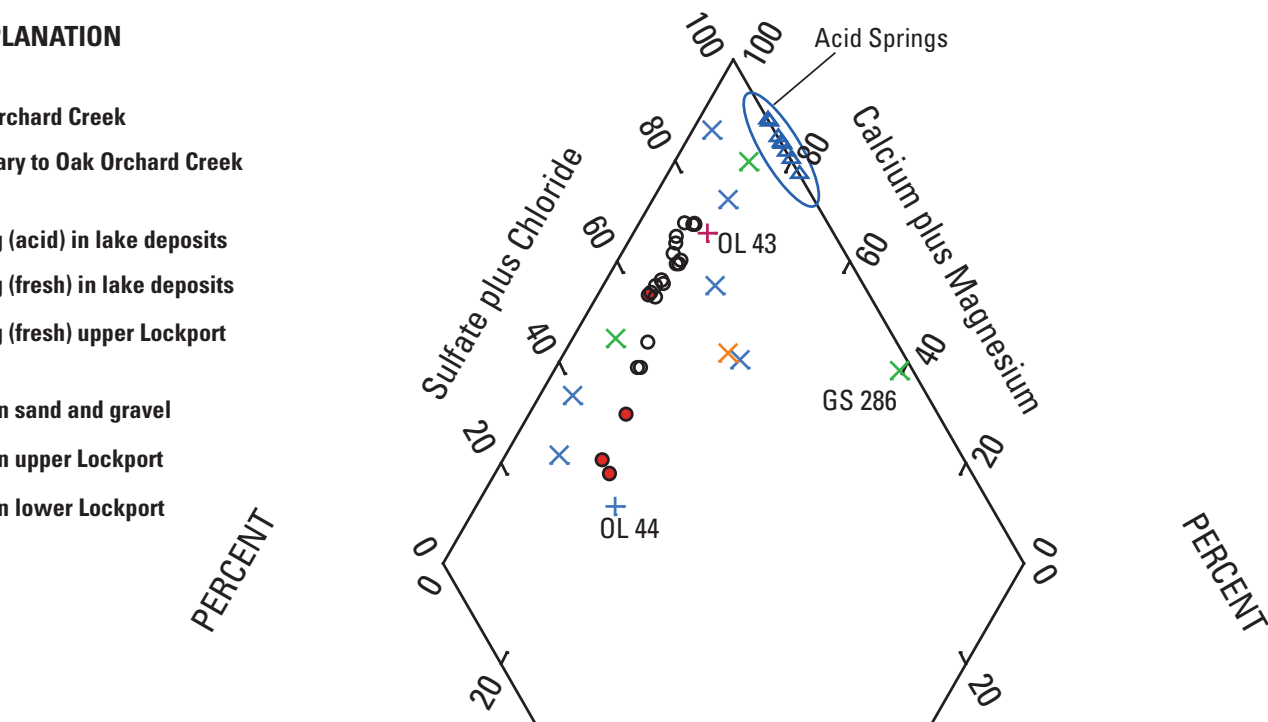

0

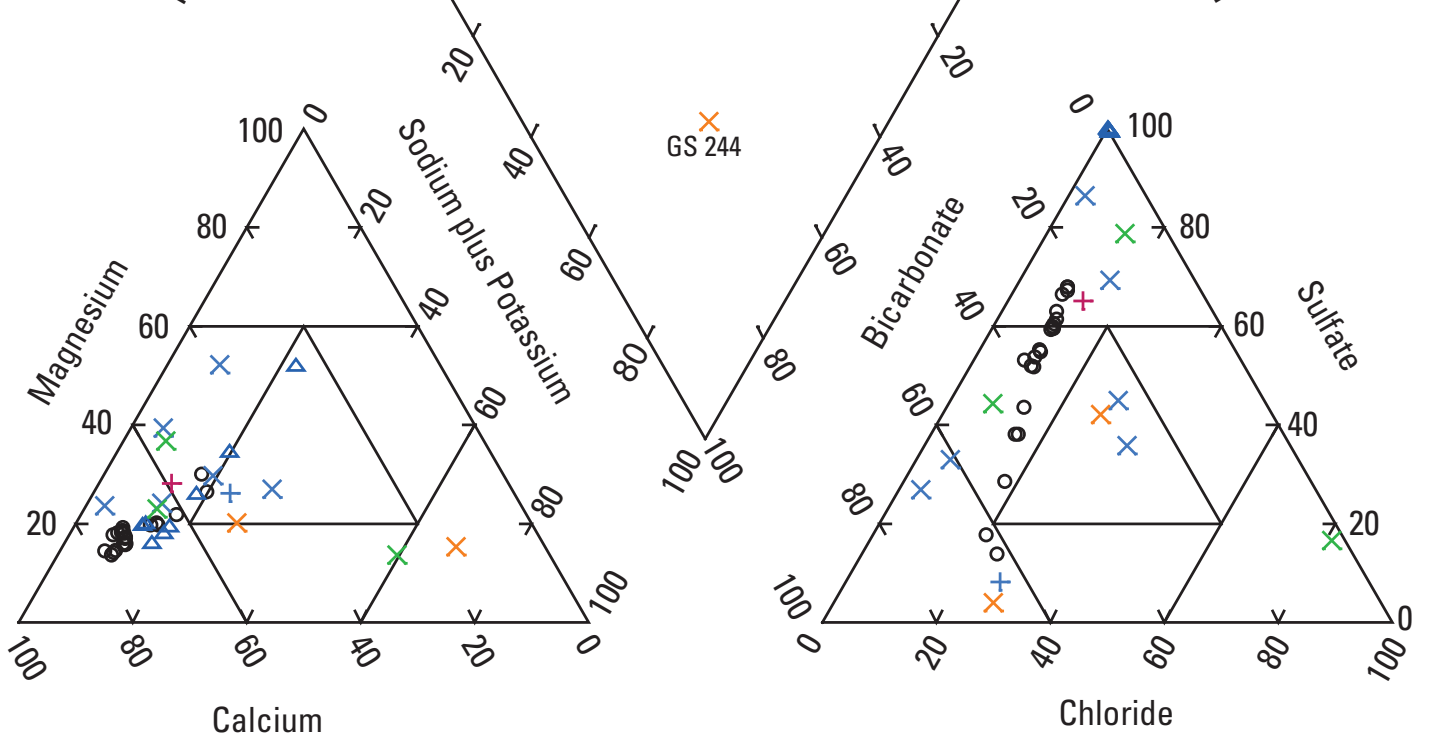

PERCENT

Figure 8. Piper diagram of major cations and anions in surface-water and groundwater samples collected in and around the Iroquois National Wildlife Refuge, Genesee and Orleans Counties, New York, 2009-10. 
bedrock at land surface, whereas the nearby Sulfur Spring (OL43) represents a calcium-sulfate-rich water discharging from lacustrine sediments, although the actual source of this water is unknown; locally, some residents speculate the water might be discharging from an old, unplugged gas well. The remaining water samples appear to align, for the most part, between these two water types.

The water types of three of the four tributary samples are close to the water quality of the OL44 endpoint (more bicarbonate than sulfate), but the water types of the remaining stream samples range from bicarbonate- to sulfate-dominated water, depending on the time of year. During high surfacewater-runoff periods in the spring, the samples from Oak Orchard Creek exhibit either a bicarbonate- or sulfatedominated ionic composition. During low-flow conditions in the summer, sulfate-type waters dominate in surface-water samples. These trends in seasonally different surface-water quality indicate that the two water types contribute to the flow in Oak Orchard Creek. The bicarbonate-type water likely originates from springs and streams discharging from the Onondaga Limestone on the south side of the watershed, generally during the spring peak-runoff period, when the sulfate-type water from the Salina Group is diluted by water from a limestone source. During summer low-flow periods, the sulfate-type water is often dominant because the discharge from the Onondaga Limestone is greatly reduced, if not totally absent.

The different sources of water were described in an independently produced Surface Water Assessment Tool (SWAT) model of the Oak Orchard Creek watershed, developed by Richards and others (2010). To have the SWAT model reproduce realistic spring-runoff volumes in Oak Orchard Creek, the model needed additional surface-water flow from outside the Oak Orchard Creek watershed to be properly calibrated; that flow was described as groundwater discharge originating from the Onondaga Limestone Escarpment. This additional flow was modeled only for the spring runoff period. Simulated flow in Oak Orchard Creek during other seasons was only from within the Oak Orchard Creek watershed, which flows across and through Salina Group shale bedrock.

Similar water-quality conditions were noted across these same bedrock units in Monroe County, N.Y., east of the study area (Hayhurst and others, 2010, p. 18). This study found that large sulfate concentrations measured in samples from Irondequoit Creek were the result of dissolution of gypsum layers found in Silurian shale (Salina Group) that crops out in that part of that watershed. Therefore, this dual-source flow system (seasonally-produced surface-water and groundwater flow from limestone and shale bedrock) produces seasonally different water quality in these watersheds and most likely elsewhere in north-central New York State where these bedrock units are present.

\section{The Oak Orchard Acid Springs}

The Oak Orchard Acid Springs are a unique feature in New York State because of their naturally low $\mathrm{pH}$ (about 2.0) and their location deep within the Oak Orchard Creek wetlands. Since their discovery in the early 1800 s, these springs have been a source of curiosity and, for a time, a source of "medicinal healing" according to those who promoted their use. Water from the spring ponds - surface discharge from these springs was minimal during the two site visits to collect water samples - was bottled and sold throughout the East Coast and purportedly shipped to the western states and Europe (North, 1899). The springs were considered unique because each had its own type of water, "three of which are acid, one sulphur, one magnesia, one iron, and one gas spring sufficient to light 50 gas burners," according to the "History of Alabama, N.Y." (North, 1899) The water became so popular that a hotel was eventually built near the springs., but by the mid- to late 1800 s, the use of the acid waters greatly declined, and the springs were all but forgotten except for the name of a nearby road-Sour Springs Road.

The quality of this acidic water from four different springs (GS290, GS291, GS292, and GS293) was initially determined in December 2009. Because of the highly unusual results (the very low $\mathrm{pH}$ of the water, the high trace metal content, and the nearly-constant discharge of natural gas from two springs), a confirming set of samples was collected in May 2010. Once the water quality of the springs was confirmed, an understanding of the physical and chemical processes that create this unique water quality was determined using two USGS geochemical models-NETPATH (Plummer and others, 1994) and PHREEQC (Parkhurst and Appelo, 1999)_to determine the possible geochemical processes that might create the acid spring waters (N. Plummer, U.S. Geological Survey, written commun., 2010). The most appropriate model, developed in NETPATH, identified oxidation of organic carbon and pyrite from the shales of the Salina Group, which resulted in the reduction of organic carbon to methane gas and the further oxidation of pyrite (specifically the sulfide in the pyrite, which lead to a large amount of sulfate in the discharged water). The result of all these reactions is sulfuric acid ( $\mathrm{pH}$ of about 2.0) and dissolved methane (as mentioned in the historic account of North, 1899). The results of the waterquality analyses of water from these springs (GS290, GS291, GS292, and GS293) can be found in appendix 1.

\section{Water-Quality Concerns and the Proposed Lockport Quarry}

The quality of water that will be discharged from the proposed quarry is of concern to managers at the Refuge because of the quality of water from the Lockport Dolomite wells at Oak Orchard Ridge Road and Sour Springs Road, and because of the quality of water from the Oak Orchard Acid 
Springs. The two USGS wells (GS286 and OL41) closest to the proposed quarry, contain typical Lockport "black water" (ferrous sulfide) at depth and natural gas (hydrogen sulfide and methane) discharges from these wells. The draft environmental impact statement (DEIS) for the quarry (Continental Placer, 2008) noted that "black water" and hydrogen sulfide were detected in the discharge from the pumped well (OL25, fig. 2) used during the 72-hour aquifer test conducted in 2007 (Continental Placer, 2008, p. 43). The position of the proposed quarry in a topographic and bedrock low also indicates that groundwater will most likely flow toward the quarry from all directions rather than from the south as is the case at the Shelby and Barre quarries. These active quarries are located farther to the north, higher in the regional topography, and closer to the Lockport Dolomite Escarpment where groundwater discharges are fresh water.

The possibility that poor-quality water ("black water," chlorides, trace metals, and methane and hydrogen sulfide gases) will be discharged during dewatering operations from the proposed quarry to one or more streams that drain into the Refuge is of concern to the Refuge managers. The quarry water would be discharged to Refuge wetland management areas and ultimately to Oak Orchard Creek. The rate of discharge from the quarry was stated to be from 260 to 2,250 gallons per minute [ 0.5 to 5.0 cubic feet per second $\left.\left(\mathrm{ft}^{3} / \mathrm{s}\right)\right]$, according to the DEIS (Continental Placer, 2008). Therefore, during summer low-flow periods, when tributary channels are normally dry and the flow of Oak Orchard Creek might be as little as $20 \mathrm{ft}^{3} / \mathrm{s}$, the contribution of the quarry discharge to Oak Orchard Creek could be as small as 2 percent or as high as 20 percent of the creek's flow. Rapid surfacewater infiltration to the groundwater system is not likely to occur because of the type of fine-grained deposits present in this part of the Oak Orchard Creek watershed. In addition, the Refuge managers are concerned about any change to the hydrology of the bedrock groundwater-flow system that alters the Oak Orchard Acid Springs. Drawdown from quarry dewatering operations, especially in the deeper excavation areas, could alter groundwater-flow paths to an extent that has not been determined but might affect the production of the acid waters in the springs located south of the proposed quarry.

\section{Summary}

A 2-year study of the water resources of the Iroquois National Wildlife Refuge in western New York was carried out during 2009-10 in cooperation with the U.S. Fish and Wildlife Service to assist Refuge managers in the development of their 15-year Comprehensive Conservation Plan. The study focused on surface-water resources of the Refuge, primarily Oak Orchard Creek; the groundwater resources that underlie the Refuge, primarily the Lockport Dolomite and overlying glacial deposits; and possible changes to these hydrologic systems as a result of the proposed development of a bedrock quarry along the north side of the Refuge.

Oak Orchard Creek was monitored seasonally for flow and water quality, and four tributary streams that flow only during early spring were also monitored. A continuous streamgage was operated on the creek just north of the Refuge. Four bedrock wells were drilled within the Refuge to characterize the glacial deposits and the bedrock beneath the Refuge. Water levels were monitored in 17 wells, and water-quality samples were collected from 11 of those wells, from 1 bedrock spring, and 5 springs discharging from glacial deposits.

Flow in Oak Orchard Creek is highly variable. During spring runoff, flows can be as great as 7 cubic feet per second per square mile $\left(\mathrm{ft}^{3} / \mathrm{s} / \mathrm{mi}^{2}\right)$, whereas during summer low flows, the discharge can be as little as $0.16 \mathrm{ft} 3 / \mathrm{s} / \mathrm{mi}^{2}$. Oak Orchard Creek has two different source areas. During spring runoff, flow from the Onondaga Limestone Escarpment, several miles south of the Refuge supplements surface runoff and groundwater discharge from the Oak Orchard Creek watershed. To a lesser degree, the Salina Group to the south and east of the Refuge and the Lockport Dolomite on the north side of the Refuge contribute to the surface-water system. During the summer and fall low-flow period, limited amounts of groundwater discharge from the Salina and Lockport bedrock units of Oak Orchard Creek and the unconsolidated sediments supply a small amount of the flow measured in the creek during this period. Water quality in the creek is affected by the seasonal variability of the quantity and quality of water from these sources.

The Lockport Dolomite underlies nearly all the Refuge, based on the results of the drilling program for this study and information from the New York State Department of Environmental Conservation Water Well Reporting Program. Between the Lockport Dolomite Escarpment and the Onondaga Limestone Escarpment, north and south of the Refuge, respectively, a bedrock trough was gouged out by multiple glacial advances. This bedrock trough was subsequently filled with mostly fine-grained sediments. Glacial Lake Tonawanda was present following the last period of glaciation about 10,000 years ago. These fine-grained sediments became the floor of the wetlands found along Oak Orchard Creek and nearby Tonawanda Creek. Water quality in the unconsolidated and bedrock aquifers is variable, with poor quality water (chlorides, "black water," and methane gas) generally present south of Oak Orchard Creek, and better quality (fresh) water present at or near the land surface in aquifers north of the Refuge in the upper Lockport Dolomite.

The Oak Orchard Acid Springs are present within the Refuge and are considered unique in New York State. The waters in these springs generally have a $\mathrm{pH}$ of about 2.0, and several springs discharge natural gas, primarily methane. These springs were popular for their supposed medicinal benefits in the mid-1800s, but are now generally disregarded. The geochemistry of these springs is apparently unique and is theorized as being the result of the position of the springs 
within the bedrock trough, their connection to the highly mineralized shale and possibly dolomitic bedrock, and the mineralogy of the sediments through which they flow and discharge from at the land surface.

The potential development of a bedrock quarry along the northern border of the Refuge is of concern to the Refuge managers. The construction of the quarry and the amount of water that could be discharged from the excavation may have an impact on the neighboring Refuge wetlands. The extent of drawdown from dewatering could change the local hydrology as well as the direction and rate of groundwater flow in the Lockport Dolomite. Although the effect on the flow of Oak Orchard Creek is expected to be minimal, changes to the local hydrology and water quality could affect the Acid Springs and the manner in which they function.

The greatest concern is the quality and amount of water that may be discharged from the quarry during dewatering operations. The quality of this discharge could include "black water" (ferrous sulfide), chlorides, trace metals, and natural gas (hydrogen sulfide and methane) from the lower Lockport Dolomite. The poor water quality was noted in the quarry draft environmental impact statement and has been documented from nearby U.S. Geological Survey monitoring wells. The additional flow to the Refuge from the dewatering of the quarry will affect the hydrology of any wetlands downstream from the quarry and possibly Oak Orchard Creek. During lowflow periods, the quantity of discharge from the quarry, when compared with the flow of Oak Orchard Creek, could be less than 2 percent of the Oak Orchard Creek flow, but as much as 20 percent of the creek flow. During low streamflow periods, the anticipated poor quality of the quarry water discharging into tributary channels with no flow could affect the ecology of the wetlands and the wildlife that use these wetlands.

\section{References Cited}

Blanchard, S.,F., 2007, Recent improvements to the U.S. Geological Survey streamgaging program...from the National Streamflow Information Program: U.S Geological Survey, FS 2007-3080, 6 p., available on-line at: http:// pubs.er.usgs.gov/usgspubs/fs/fs20073080/.

Brett, C.E., Tepper, D.H., Goodman, W.M., LoDuca, S.T., and Eckert, Bea-Yeh, 1995, Revised stratigraphy and correlation of the Niagaran provincial series (Medina, Clinton, and Lockport groups) in the type area of western New York: U.S. Geological Survey Bulletin 2086, 66 p.

Buchanan, T.J., and Somers, W.P., 1982, Stage measurement at gaging stations: U.S. Geological Survey Techniques of Water-Resource Investigations of the United States Geological Survey, book 3, chap. A7, Applications of Hydraulics, 28p.
Cadwell, D.H., 1988, Surficial geologic map of New York Niagara Sheet: Albany, New York, New York State Museum Map and Chart Series, no. 40, 1 sheet, 1:250,000 scale.

Continental Placer, 2008, Draft environmental impact statement for a mine land use plan mining permit, town of Shelby, Orleans County, New York: Albany, N.Y., v. 1, $191 \mathrm{p}$.

Gowan, S.W., 1988, Hydrogeologic evaluation of a proposed stone quarry site in the town of Clarendon, N.Y.: Albany, N.Y., Dunn Geoscience Corporation, 43 p.

Hayhurst, B.A., Coon, W.F., and Eckhardt, D.A., 2010, Water resources of Monroe County, New York, water years 200308-Streamflow, constituent loads, and trends in water quality: U.S. Geological Survey Scientific Investigations Report 2010-5216, 34 p.

Iroquois National Wildlife Refuge, [undated], About us: U.S. Fish and Wildlife Iroquois National Wildlife Refuge, accessed May 2010, at http://www.fws.gov/northeast/ iroquois/aboutus.html.

Kindle, E.M., and Taylor, F.B., 1913, Geologic atlas of the United States, Niagara folio: U.S. Geological Survey Folio $190,26 \mathrm{p}$.

Makarewicz, J.C., and Lewis, T.W., 2009, Oak Orchard Creek watershed - the location of sources of pollution, annual loss of nutrients and soil to Lake Ontario, and a test of effectiveness of zone tillage as a best management practice: Brockport, N.Y., The Department of Environmental Science and Biology, State University of New York at Brockport, $136 \mathrm{p}$.

Michelson, D.M., Clayton, L., Fullerton, D.S., and Borns, H.W. Jr., 1983, The late Wisconsin glacial record in the United States, in Wright H.E., Jr., ed., Later Quaternary environments of the United States, v. 1, the Late Pleistocene: Minneapolis, Minnesota, University of Minnesota Press, p. 3-37.

Miller, T.S., and Kappel W.M., 1987, Effect of the Niagara Power Project on groundwater flow in the upper part of the Lockport Dolomite, Niagara Falls area, New York: U.S. Geological Survey Water-Resources Investigations Report 86-4130, 31 p., 2 pls.

North, S.E., 1899, History of Alabama, N.Y.-from our county and its people a descriptive and biographical record of Genesee County New York: The Boston History Company, accessed August 2009, at http://history.rays-place.com/ny/ alabama-ny.htm. 
Parkhurst, D.L. and Appelo, C.A.J., 1999, User's guide to PHREEQC (Version2)-A computer program for speciation, batch-reaction, one-dimensional transport, and inverse geochemical calculations: U.S. Geological Survey Water-Resources Investigations Report 99-4259, 310 p.

Piper, A.M., 1944, A graphic procedure in the geochemical interpretation of water-analyses: Geophysical Union Transactions, v. 25, p. 914-923.

Plummer, L.N., Prestemon, E.C., and Parkhurst, D.L., 1994, An interactive code (NETPATH) for modeling NET geochemical reactions along a groundwater flow PATH, Version 2.0, U.S. Geological Survey, Water-Resources Investigations Report 94-4169, $130 \mathrm{p}$.

Rantz, S.E., and others, 1982, Computation of discharge, v. 2 of Measurement and computation of streamflow: Water Supply Paper 2175, p. 285-631.

Richards, P.L., Lewis, T.W., Makarewicz, J.C., and Zollweg, James, 2010, The Oak Orchard soil water assessment tool -a decision support system for watershed management -Part 1. Calibration and validation: Brockport, N.Y., Departments of Earth Science and of Environmental Science and Biology, State University of New York at Brockport, 34 p.
Staubitz, W.W., and Miller, T.S., 1987, Geology and hydrology of the Onondaga aquifer in eastern Erie County, New York, with emphasis on ground-water-level declines since 1982: U.S. Geological Survey Water-Resources Investigations Report 86-4317, 44 p., 4 pls.

Stone, B.D., 1995, Progress toward higher resolution of the late Wisconsinan chronology of the New England region, 30 to $13 \mathrm{ka}$ : Geological Society of American Northeastern Section Abstracts with Programs, p. 84.

Teller, J.T., 1987, Proglacial lakes and the southern margin of the Laurentide ice sheet, in Ruddiman, W.F., and Wright, H.E., Jr., eds., North America and adjacent oceans during the last deglaciation: Boulder, Colorado, Geological Society of American, The Geology of North America, v. K-3, p. 39-69.

U.S. Geological Survey, variously dated, National field manual for the collection of water-quality data: U.S. Geological Survey Techniques of Water Resource Investigations, book 9, chaps. A1-A9, available online at http://pubs.water.usgs. gov/twri9A.

Zenger, D.H., 1962, Proposed stratigraphic nomenclature for Lockport Formation (Middle Silurian) in New York State: American Association of Petroleum Geologists Bulletin, v. 30 , p. $477-513$. 
This page has been left blank intentionally. 
Appendix 1. Results of Water-Quality Analyses of Samples from Streams, Wells, and Springs in and around the Iroquois National Wildlife Refuge, November 2008 to November 2010. (Tables 1-1 through 1-10) 
Table 1-2 27

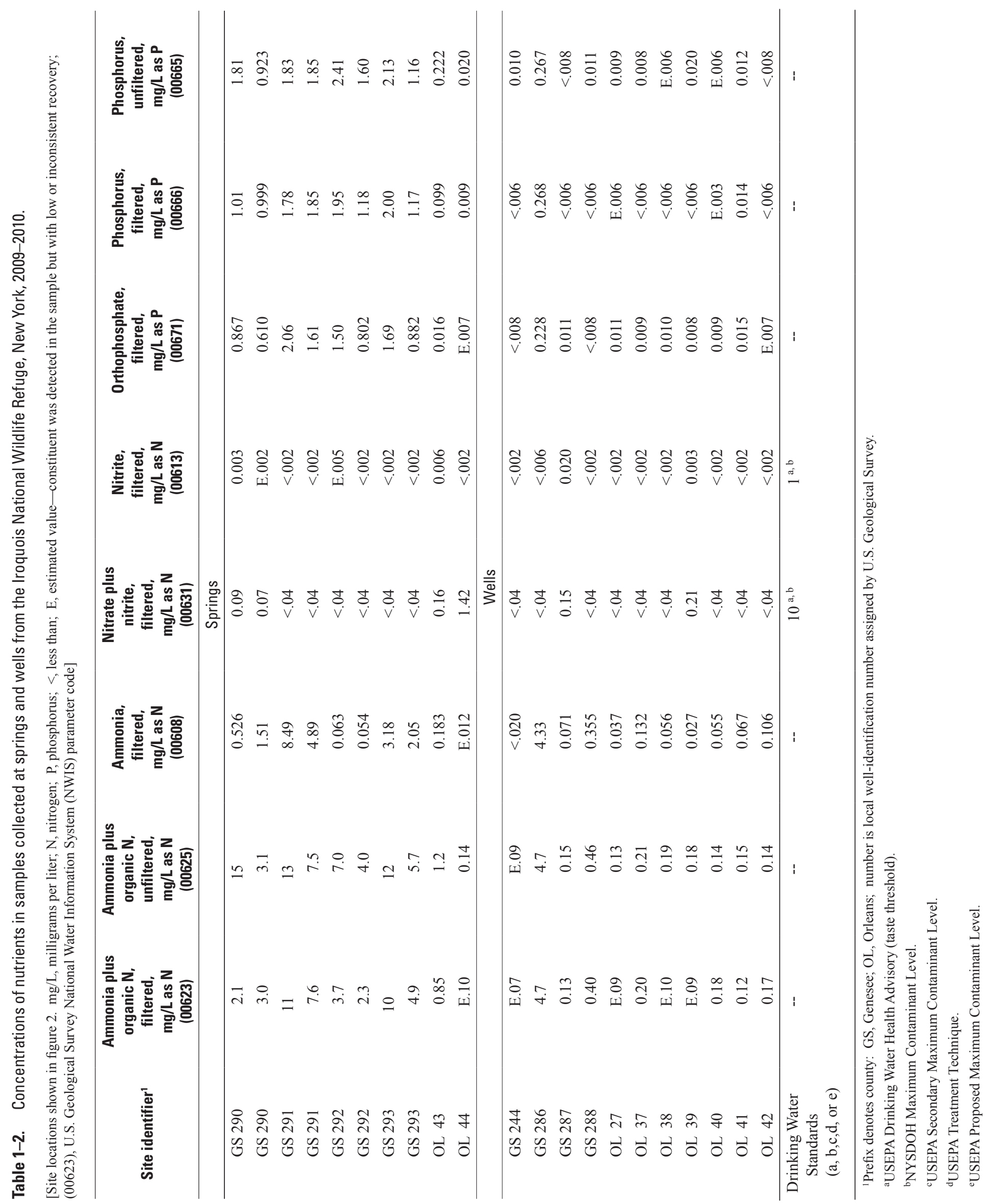




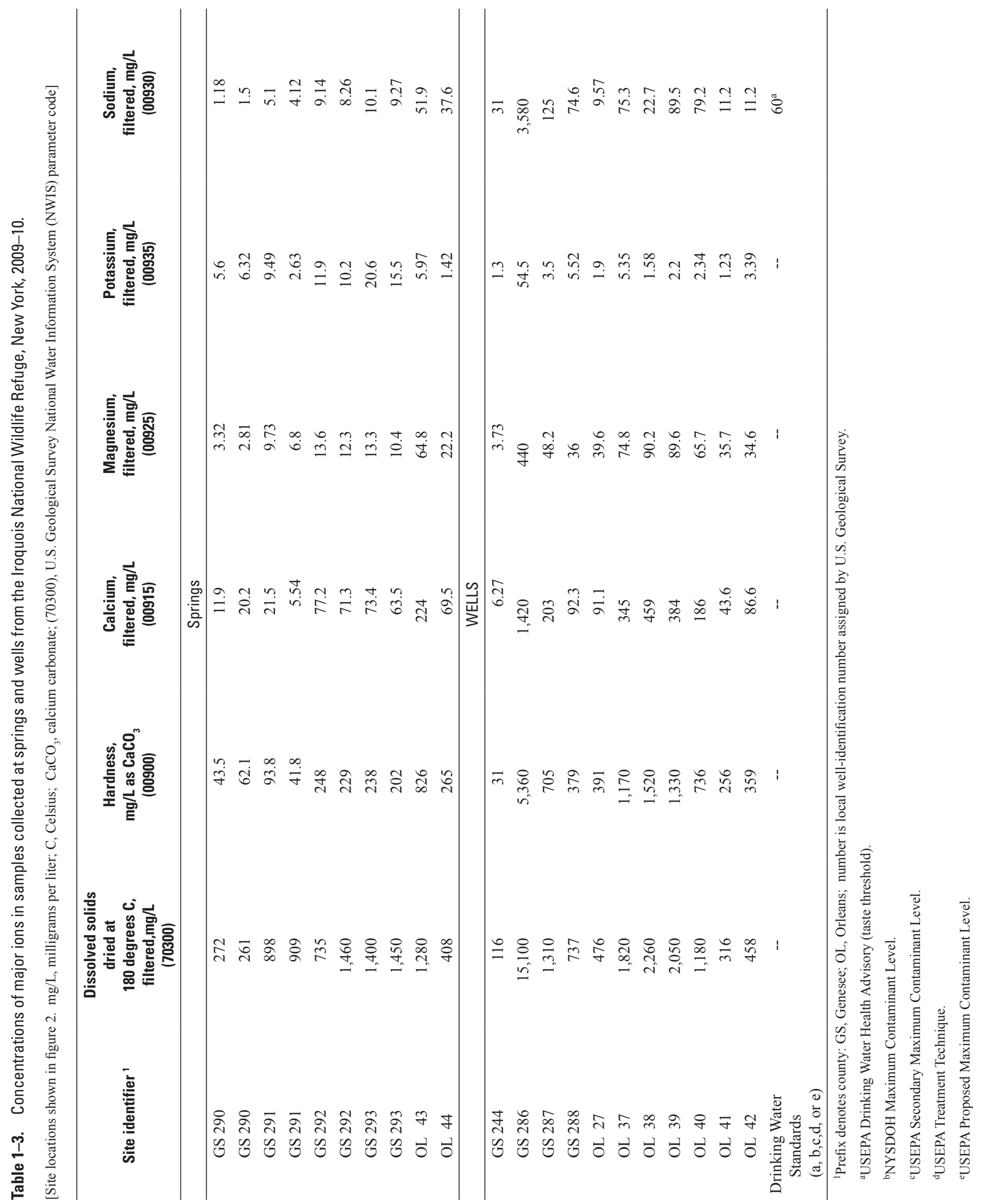


Table 1-4. Concentrations of major ions in samples collected from springs and wells at the Iroquois National Wildlife Refuge, New York, 2009-10.

[Site locations shown in figure 2. $\mathrm{mg} / \mathrm{L}$, milligrams per liter; $\mathrm{C}$, Celsius; $\mathrm{CaCO}_{3}$, calcium carbonate; $\mathrm{SiO}$, silica dioxide; --, no information; <, less than; E, estimated value - constituent was detected in the sample but with low or inconsistent recovery; (29801), U.S. Geological Survey National Water Information System (NWIS) parameter code]

\begin{tabular}{|c|c|c|c|c|c|c|c|}
\hline Site identifier ${ }^{1}$ & $\begin{array}{c}\text { Alkalinity }^{2} \\
\text { filtered, } \\
\text { mg/L as CaCO } \\
\text { (29801) }\end{array}$ & $\begin{array}{c}\text { Bicarbonate }^{3} \\
\text { filtered, } \\
\mathrm{mg} / \mathrm{L}_{\text {as } \mathrm{CaCO}} \\
\text { (29805) }\end{array}$ & $\begin{array}{c}\text { Bromide, } \\
\text { filtered, } \\
\mathrm{mg} / \mathrm{L} \\
(71870)\end{array}$ & $\begin{array}{c}\text { Chloride, } \\
\text { filtered, } \\
\mathrm{mg} / \mathrm{L} \\
(00940)\end{array}$ & $\begin{array}{c}\text { Fluoride } \\
\text { filtered, } \\
\mathrm{mg} / \mathrm{L} \\
(00950)\end{array}$ & $\begin{array}{c}\text { Silica, } \\
\text { filtered, } \\
\mathrm{mg} / \mathrm{L} \text { as } \mathrm{SiO}{ }_{2} \\
\text { (00955) }\end{array}$ & $\begin{array}{c}\text { Sulfate, } \\
\text { filtered, } \\
\mathrm{mg} / \mathrm{L} \\
(00945)\end{array}$ \\
\hline GS 290 & $<8$ & $<8$ & 0.02 & 1.16 & $<.08$ & 13.6 & 177 \\
\hline GS 290 & -- & -- & $<.02$ & 0.69 & E.08 & 13.1 & 279 \\
\hline GS 291 & -- & -- & E.01 & 1.48 & 0.16 & 63.4 & 887 \\
\hline GS 292 & $<8$ & $<8$ & E.02 & 12.7 & E.08 & 27.2 & 1,870 \\
\hline GS 292 & -- & -- & E.02 & 12.0 & 0.14 & 20.9 & 1,730 \\
\hline GS 293 & $<8$ & $<8$ & 0.02 & 10.3 & E.07 & 73.7 & 2,440 \\
\hline GS 293 & -- & -- & 0.02 & 10.5 & 0.16 & 44.0 & 1,660 \\
\hline \multicolumn{8}{|c|}{ Wells } \\
\hline GS 244 & 70 & 85 & -- & 20.5 & 0.64 & 2.55 & 3.98 \\
\hline GS 286 & 278 & 339 & -- & 7,050 & 1.42 & 13.2 & 1,960 \\
\hline GS 287 & 301 & 367 & -- & 197 & 0.32 & 16.7 & 405 \\
\hline GS 288 & 169 & 206 & -- & 149 & 1.03 & 12.3 & 203 \\
\hline OL 27 & 239 & 292 & -- & 16.7 & 0.78 & 17.2 & 124 \\
\hline OL 37 & 100 & 122 & -- & 130 & 1.07 & 17.2 & 1,010 \\
\hline OL 38 & 176 & 215 & -- & 34.6 & 1.52 & 16.7 & 1,370 \\
\hline OL 39 & 232 & 283 & -- & 176 & 1.28 & 16.2 & 1,040 \\
\hline
\end{tabular}

${ }^{1}$ Prefix denotes county: GS, Genesee; OL, Orleans; number is local well-identification number assigned by U.S. Geological Survey.

${ }^{2}$ Fixed-endpoint titration at $\mathrm{pH} 4.5$.

${ }^{3}$ Calculated from alkalinity.

${ }^{a}$ USEPA Drinking Water Health Advisory (taste threshold).

${ }^{b} \mathrm{NYSDOH}$ Maximum Contaminant Level.

'USEPA Secondary Maximum Contaminant Level.

dUSEPA Treatment Technique.

'USEPA Proposed Maximum Contaminant Level. 


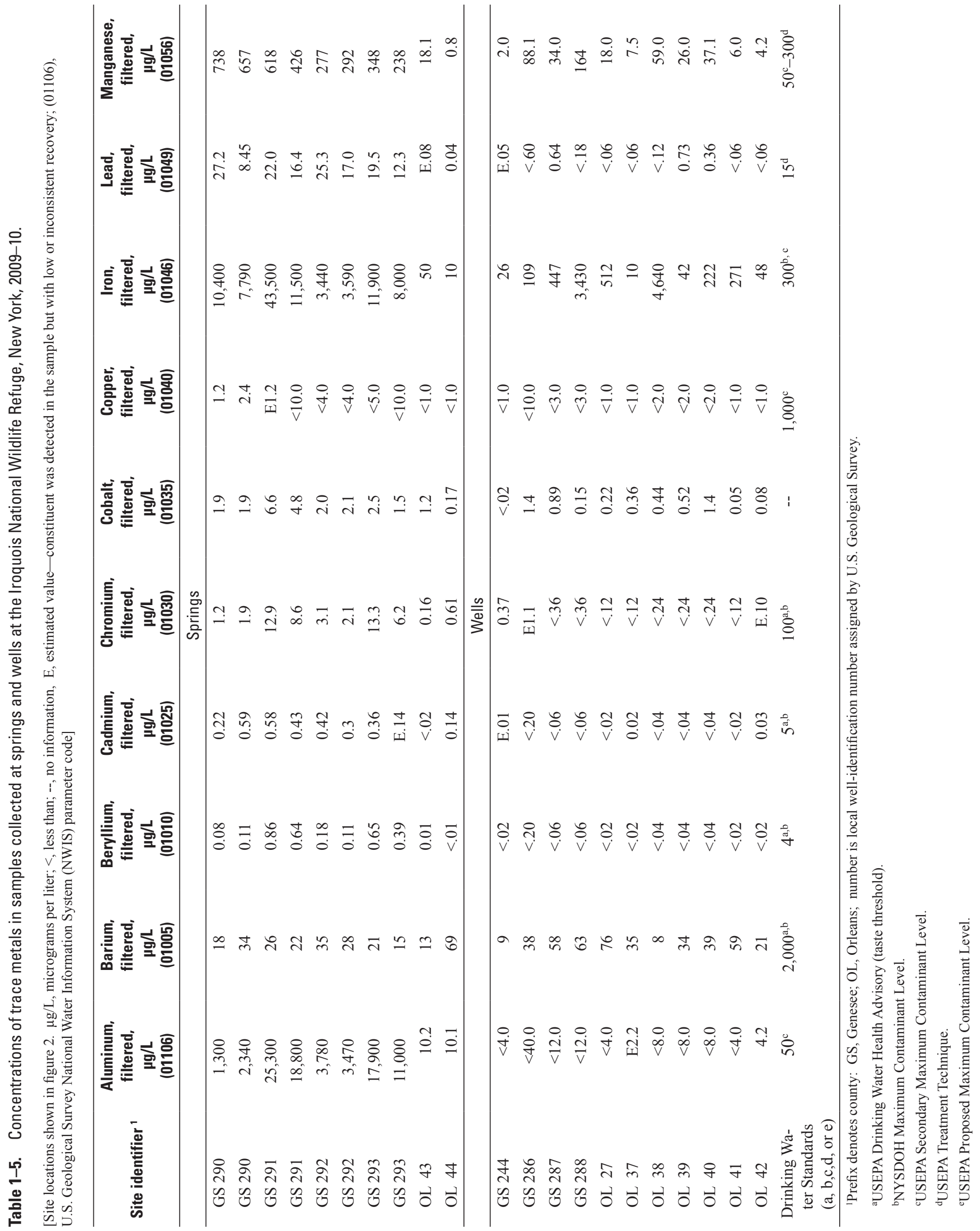




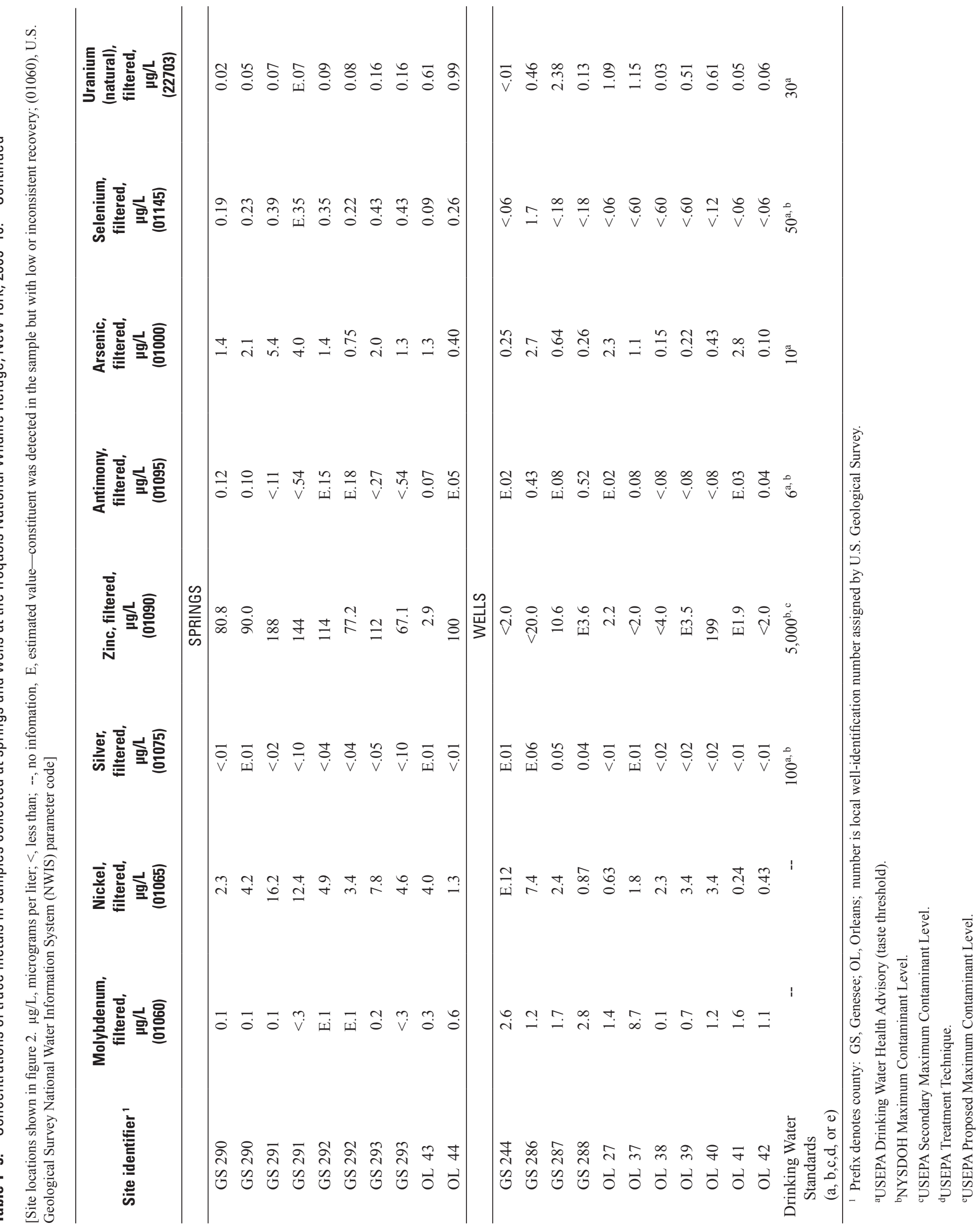


Table 1-6. Site information and physical properties of stream samples collected at the Iroquois National Wildlife Refuge, New York, 2008-10.

[Site locations shown in figure 2. --, no data; $\mathrm{mi}^{2}$, drainage area in square miles; (00300), U.S. Geological Survey National Water Information System (NWIS) parameter code]

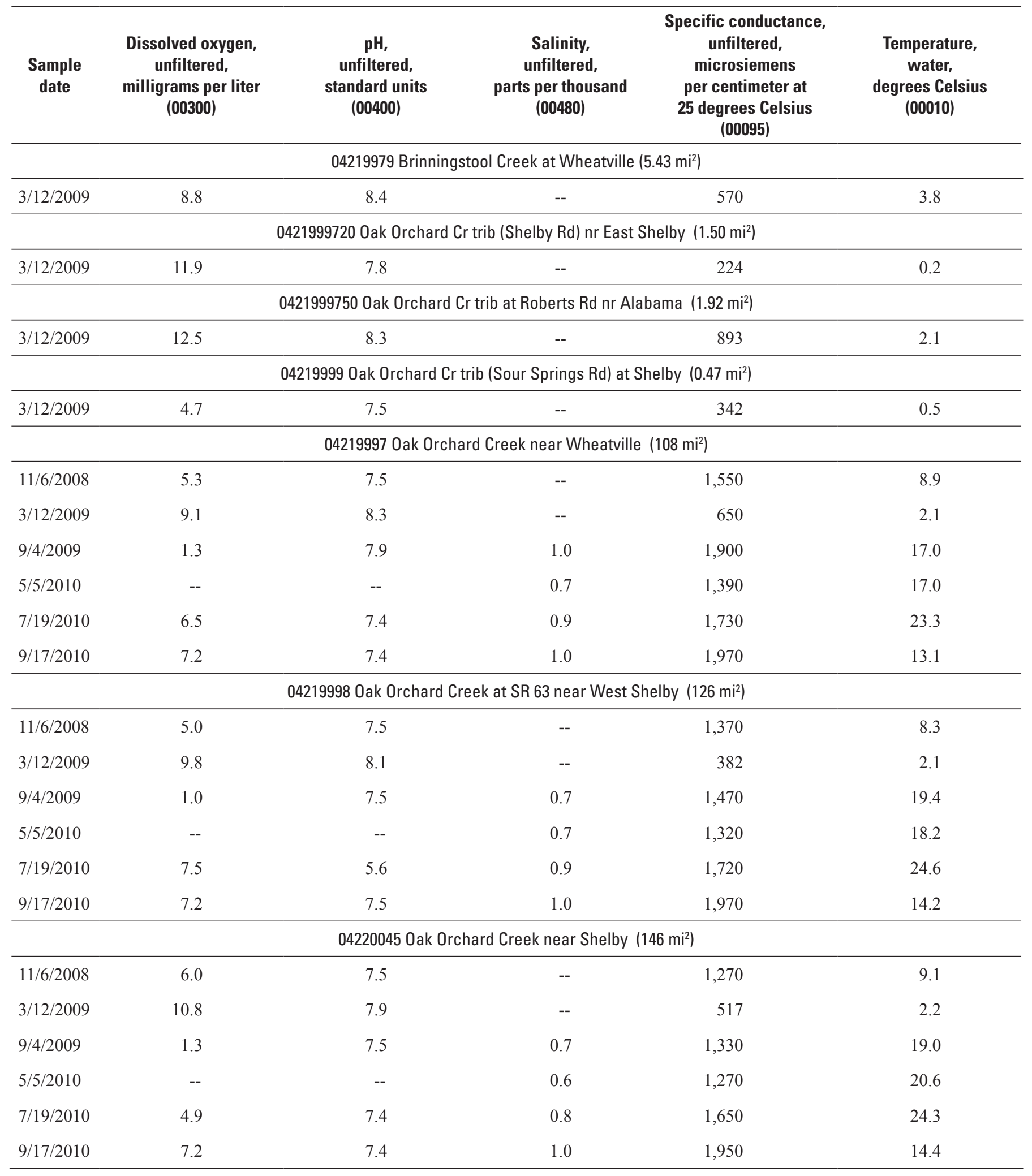


Table 1-7. Concentrations of nutrients in stream samples collected at the Iroquois National Wildlife Refuge, New York, 2008-10.

[Site locations shown in figure 2. mg/L, milligrams per liter; N, nitrogen; P, phosphorus; E, estimated value — constituent was detected in the sample but with low or inconsistent recovery; (00623), U.S. Geological Survey National Water Information System (NWIS) parameter code]

\begin{tabular}{|c|c|c|c|c|c|c|c|c|}
\hline $\begin{array}{c}\text { Sample } \\
\text { date }\end{array}$ & $\begin{array}{c}\text { Ammonia plus } \\
\text { organic N, } \\
\text { filtered, } \\
\text { mg/L as N } \\
\text { (00623) }\end{array}$ & $\begin{array}{c}\text { Ammonia plus } \\
\text { organic N, } \\
\text { unfiltered, } \\
\text { mg/L as N } \\
\text { (00625) }\end{array}$ & $\begin{array}{c}\text { Ammonia, } \\
\text { filtered, } \\
\text { mg/L as N } \\
(00608)\end{array}$ & $\begin{array}{l}\text { Nitrate plus } \\
\text { nitrite, } \\
\text { filtered, } \\
\text { mg/L as N } \\
\text { (00631) }\end{array}$ & $\begin{array}{c}\text { Nitrite, } \\
\text { filtered, } \\
\text { mg/L as N } \\
(00613)\end{array}$ & $\begin{array}{c}\text { Orthophosphate, } \\
\text { filtered, } \\
\text { mg/L as P } \\
\text { (00671) }\end{array}$ & $\begin{array}{l}\text { Phosphorus, } \\
\text { filtered, } \\
\text { mg/L as P } \\
\text { (00666) }\end{array}$ & $\begin{array}{c}\text { Phosphorus, } \\
\text { unfiltered, } \\
\text { mg/L as } P \\
\text { (00665) }\end{array}$ \\
\hline \multicolumn{9}{|c|}{04219979 Brinningstool Creek at Wheatville (5.43 $\left.\mathrm{mi}^{2}\right)$} \\
\hline $3 / 12 / 2009$ & 0.62 & 0.93 & 0.079 & 2.63 & 0.013 & 0.093 & 0.107 & 0.213 \\
\hline \multicolumn{9}{|c|}{0421999720 Oak Orchard Creek tributary (Shelby Road) near East Shelby (1.50 mi²) } \\
\hline $3 / 12 / 2009$ & 0.5 & 0.82 & $<.020$ & 0.41 & 0.003 & 0.016 & 0.033 & 0.146 \\
\hline \multicolumn{9}{|c|}{0421999750 Oak Orchard Creek tributary at Roberts Road near Alabama (1.92 mi mi²) } \\
\hline $3 / 12 / 2009$ & 0.99 & 1.2 & 0.337 & 1.95 & 0.015 & 0.074 & 0.091 & 0.147 \\
\hline \multicolumn{9}{|c|}{04219999 Oak Orchard Creek tributary (Sour Springs Road) at Shelby (0.47 $\left.\mathrm{mi}^{2}\right)$} \\
\hline $3 / 12 / 2009$ & 0.57 & 0.79 & 0.044 & 0.38 & 0.003 & 0.034 & 0.056 & 0.161 \\
\hline \multicolumn{9}{|c|}{04219997 Oak Orchard Creek near Wheatville $\left(108 \mathrm{mi}^{2}\right)$} \\
\hline $11 / 6 / 2008$ & 1.5 & 1.9 & 0.052 & 3.96 & 0.030 & 0.221 & 0.249 & 0.400 \\
\hline $3 / 12 / 2009$ & 0.97 & 1.2 & 0.056 & 2.19 & 0.014 & 0.199 & 0.236 & 0.294 \\
\hline 9/4/2009 & 0.84 & 1.5 & 0.037 & 2.49 & 0.010 & 0.194 & 0.229 & 0.585 \\
\hline $5 / 5 / 2010$ & 0.92 & 1.7 & 0.081 & 1.42 & 0.036 & 0.128 & 0.165 & 0.492 \\
\hline $7 / 19 / 2010$ & 0.97 & 2.0 & 0.064 & 3.62 & 0.025 & 0.523 & 0.562 & 0.999 \\
\hline 9/17/2010 & 1.2 & 2.7 & 0.111 & 2.49 & 0.016 & 0.193 & 0.229 & 0.810 \\
\hline \multicolumn{9}{|c|}{04219998 Oak Orchard Creek at SR63 near West Shelby (126 mi²) } \\
\hline $11 / 6 / 2008$ & 1.5 & 1.6 & 0.055 & 2.92 & 0.027 & 0.198 & 0.230 & 0.289 \\
\hline $3 / 12 / 2009$ & 0.8 & 0.95 & E.019 & 1.79 & 0.013 & 0.152 & 0.167 & 0.226 \\
\hline 9/4/2009 & 1.1 & 1.6 & 0.049 & 1.17 & 0.010 & 0.214 & 0.256 & 0.572 \\
\hline $5 / 5 / 2010$ & 0.85 & 1.5 & 0.075 & 1.03 & 0.020 & 0.111 & 0.142 & 0.309 \\
\hline $7 / 19 / 2010$ & 1.1 & 2.1 & 0.122 & 2.27 & 0.038 & 0.269 & 0.314 & 0.721 \\
\hline 9/17/2010 & 0.86 & 1.2 & 0.049 & 2.09 & 0.011 & 0.185 & 0.194 & 0.365 \\
\hline \multicolumn{9}{|c|}{04220045 Oak Orchard Creek near Shelby (146 $\left.\mathrm{mi}^{2}\right)$} \\
\hline $11 / 6 / 2008$ & 1.4 & 1.5 & 0.037 & 2.42 & 0.026 & 0.176 & 0.197 & 0.246 \\
\hline $3 / 12 / 2009$ & 0.75 & 0.97 & 0.023 & 1.48 & 0.013 & 0.105 & 0.126 & 0.189 \\
\hline 9/4/2009 & 1.1 & 1.3 & 0.053 & 0.77 & 0.010 & 0.206 & 0.255 & 0.423 \\
\hline $5 / 5 / 2010$ & 1.1 & 1.4 & 0.076 & 0.95 & 0.018 & 0.087 & 0.129 & 0.306 \\
\hline $7 / 19 / 2010$ & 1.3 & 1.9 & 0.141 & 1.79 & 0.028 & 0.247 & 0.284 & 0.459 \\
\hline 9/17/2010 & 0.84 & 1.2 & 0.033 & 1.90 & 0.008 & 0.147 & 0.167 & 0.348 \\
\hline
\end{tabular}


Table 1-8. Concentrations of major ions in stream samples collected at the Iroquois National Wildlife Refuge, New York, 2008-10.

[Site locations shown in figure 2. mg/L, milligrams per liter; $\mathrm{CaCO}_{3}$, calcium carbonate; <, less than; (70300), U.S. Geological Survey National Water Information System (NWIS) parameter code]

\begin{tabular}{|c|c|c|c|c|c|c|}
\hline $\begin{array}{c}\text { Sample } \\
\text { date }\end{array}$ & $\begin{array}{c}\text { Dissolved solids } \\
\text { dried at } 180 \text { de- } \\
\text { grees Celsius, } \\
\text { filtered, } \\
\text { mg/L } \\
(70300)\end{array}$ & $\begin{array}{c}\text { Hardness, } \\
\text { filtered, } \\
\text { mg/L as } \mathrm{CaCO}_{3} \\
(00900)\end{array}$ & $\begin{array}{c}\text { Calcium, filtered, } \\
\text { mg/L } \\
(00915)\end{array}$ & $\begin{array}{c}\text { Magnesium, } \\
\text { filtered, } \\
\text { mg/L } \\
(00925)\end{array}$ & $\begin{array}{c}\text { Potassium, } \\
\text { filtered, } \\
\text { mg/L } \\
(00935)\end{array}$ & $\begin{array}{c}\text { Sodium, } \\
\text { filtered, } \\
\text { mg/L } \\
(00930)\end{array}$ \\
\hline \multicolumn{7}{|c|}{04219979 Brinningstool Creek at Wheatville $\left(5.43 \mathrm{mi}^{2}\right)$} \\
\hline \multicolumn{7}{|c|}{0421999720 Oak Orchard Creek tributary (Shelby Road) near East Shelby (1.50 mi²) } \\
\hline $3 / 12 / 2009$ & 141 & 87.7 & 23.6 & 6.97 & 2.76 & 8.63 \\
\hline \multicolumn{7}{|c|}{0421999750 Oak Orchard Creek tributary at Roberts Road near Alabama (1.92 mi²) } \\
\hline $3 / 12 / 2009$ & 601 & 423 & 134 & 21.2 & 7.34 & 15.4 \\
\hline \multicolumn{7}{|c|}{04219999 Oak Orchard Creek tributary (Sour Springs Road) at Shelby (0.47 mi²) } \\
\hline \multicolumn{7}{|c|}{04219997 Oak Orchard Creek near Wheatville (108 mi²) } \\
\hline $11 / 6 / 2008$ & 1,240 & 818 & 266 & 37.6 & 8.07 & 29.2 \\
\hline $3 / 12 / 2009$ & 316 & 212 & 65.0 & 11.9 & 4.96 & 13.7 \\
\hline $9 / 4 / 2009$ & 1,620 & 1,090 & 369 & 40.8 & 8.46 & 40.6 \\
\hline $5 / 5 / 2010$ & 1,040 & 718 & 231 & 34.2 & 4.31 & 34.0 \\
\hline $7 / 19 / 2010$ & 1,390 & 895 & 295 & 38.3 & 12.8 & 45.4 \\
\hline $9 / 17 / 2010$ & 1,660 & 1,110 & 378 & 40.0 & 11.0 & 49.7 \\
\hline $5 / 5 / 2010$ & 954 & 653 & 209 & 31.9 & 3.77 & 29.5 \\
\hline $7 / 19 / 2010$ & 1,380 & 916 & 304 & 38.5 & 12.9 & 46.3 \\
\hline $9 / 17 / 2010$ & 1,650 & 1,090 & 366 & 41.6 & 11.5 & 50.5 \\
\hline \multicolumn{7}{|c|}{04220045 Oak Orchard Creek near Shelby $\left(146 \mathrm{mi}^{2}\right)$} \\
\hline $11 / 6 / 2008$ & 972 & 610 & 196 & 29.3 & 7.32 & 24.7 \\
\hline $3 / 12 / 2009$ & 317 & 222 & 69.1 & 12.1 & 4.58 & 13.7 \\
\hline $9 / 4 / 2009$ & 985 & 673 & 218 & 30.9 & 6.17 & 33.2 \\
\hline $5 / 5 / 2010$ & 918 & 644 & 206 & 31.3 & 4.00 & 28.5 \\
\hline $7 / 19 / 2010$ & 1,320 & 856 & 283 & 36.4 & 11.1 & 41.8 \\
\hline $9 / 17 / 2010$ & 1,640 & 1,080 & 367 & 40.3 & 10.8 & 49.3 \\
\hline
\end{tabular}


Table 1-9. Concentrations of major ions in stream samples collected at the Iroquois National Wildlife Refuge, New York, 2008-10.

[Site locations shown in figure 2. mg/L, milligrams per liter; $\mathrm{CaCO}_{3}$, calcium carbonate; $\mathrm{SiO}_{2}$, silica dioxide; --, no information; E, estimated value-constituent was detected in the sample but with low or inconsistent recovery; (29801), U.S. Geological Survey National Water Information System (NWIS) parameter code; alkalinity determined from fixed-endpoint titration to $\mathrm{pH} 4.5$; bicarbonate concentration calculated from alkalinity concentration]

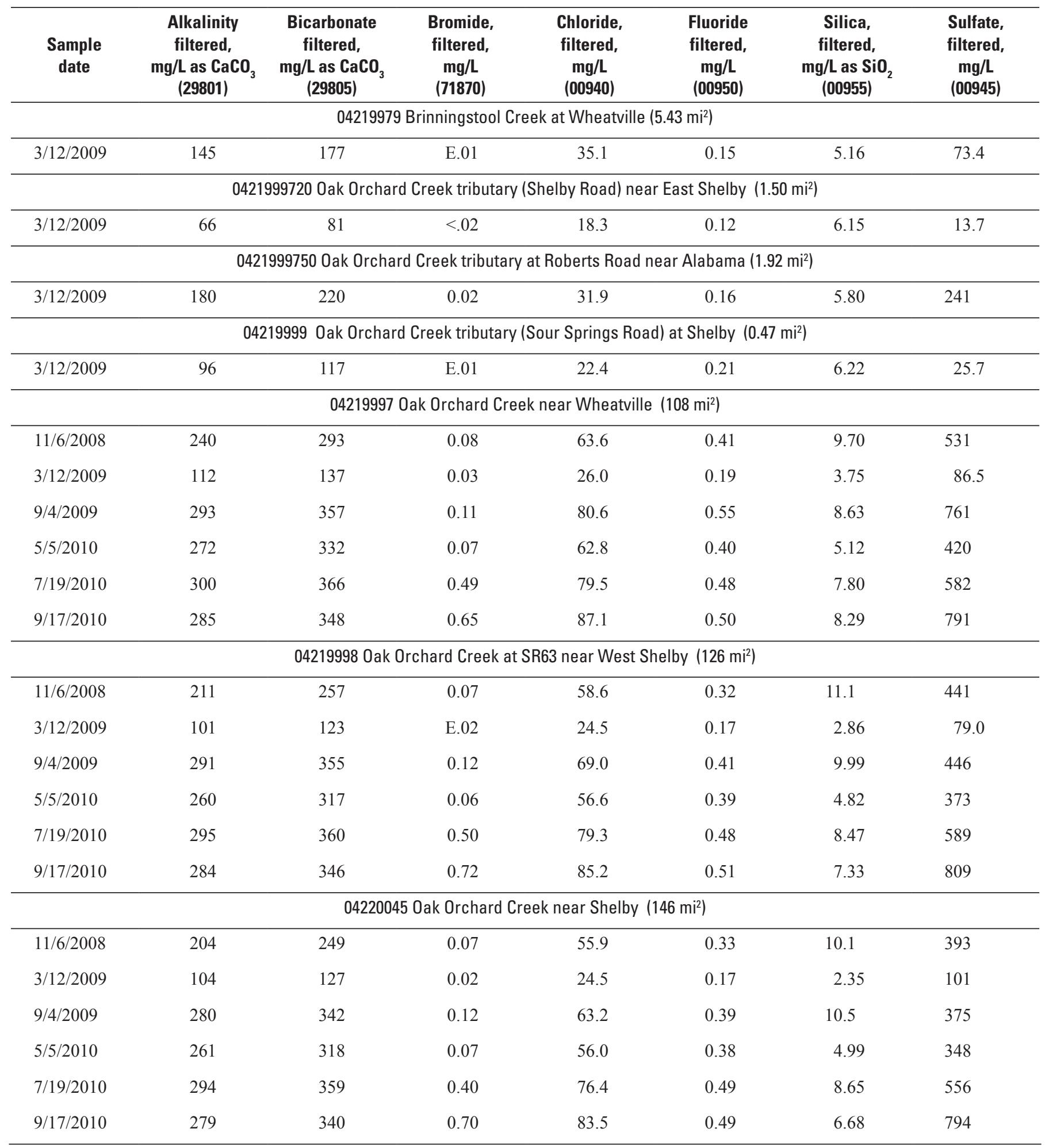




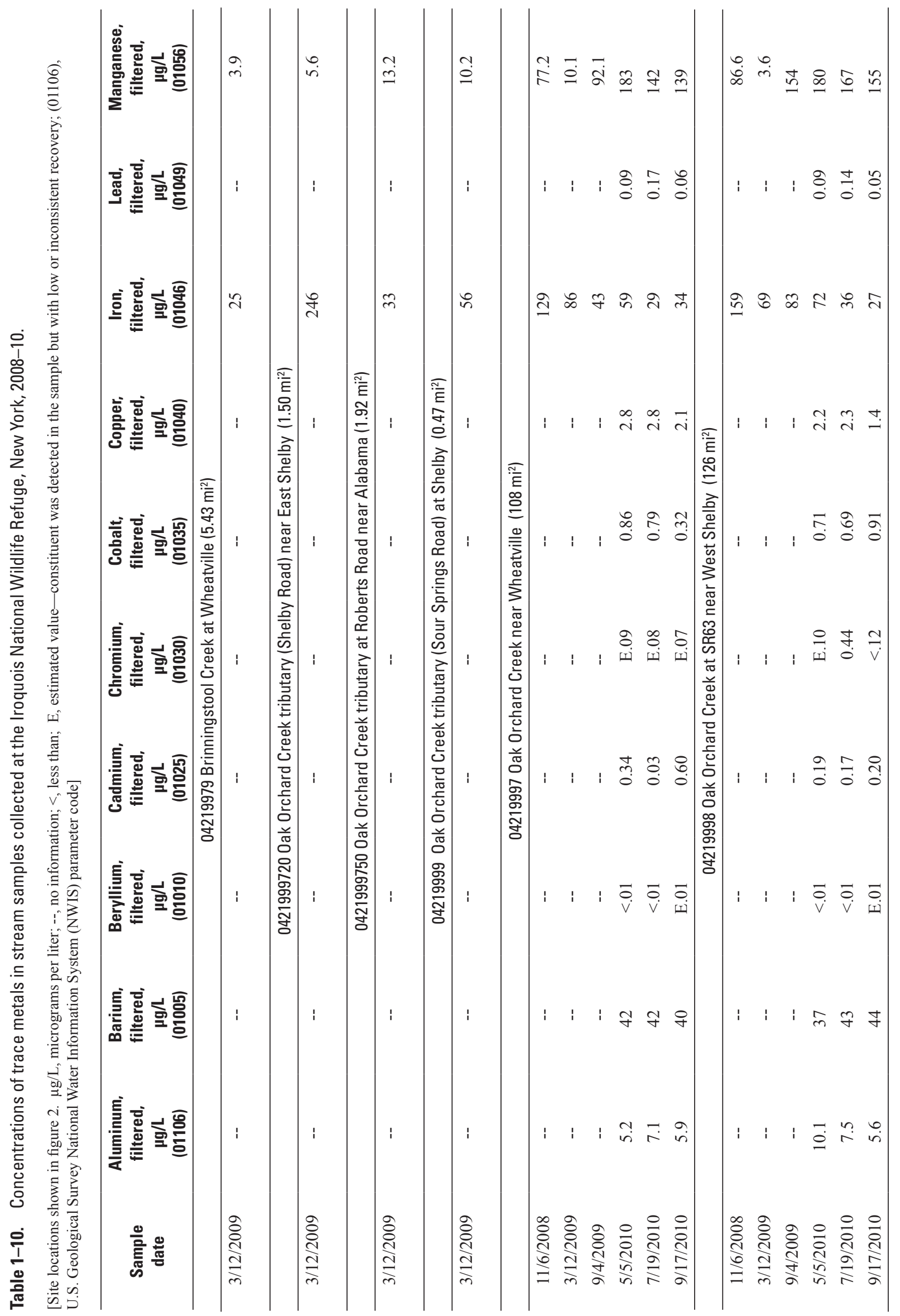


Table 1-10 37

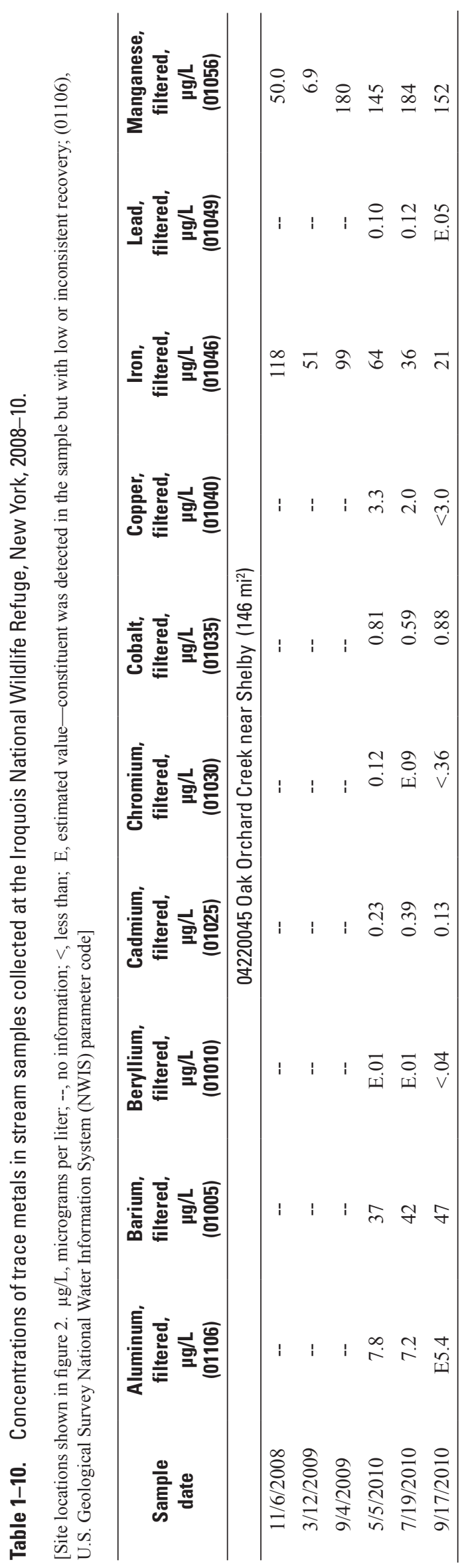


This page has been left blank intentionally. 
Appendix 2. Hydrographs of 17 Groundwater-Monitoring Wells in and around the Iroquois National Wildlife Refuge, 3 Regional Groundwater Wells, and 2 Stream Sites of Oak Orchard Creek at Sour Springs Road and Harrison Road, November 2008 to November 2010. 


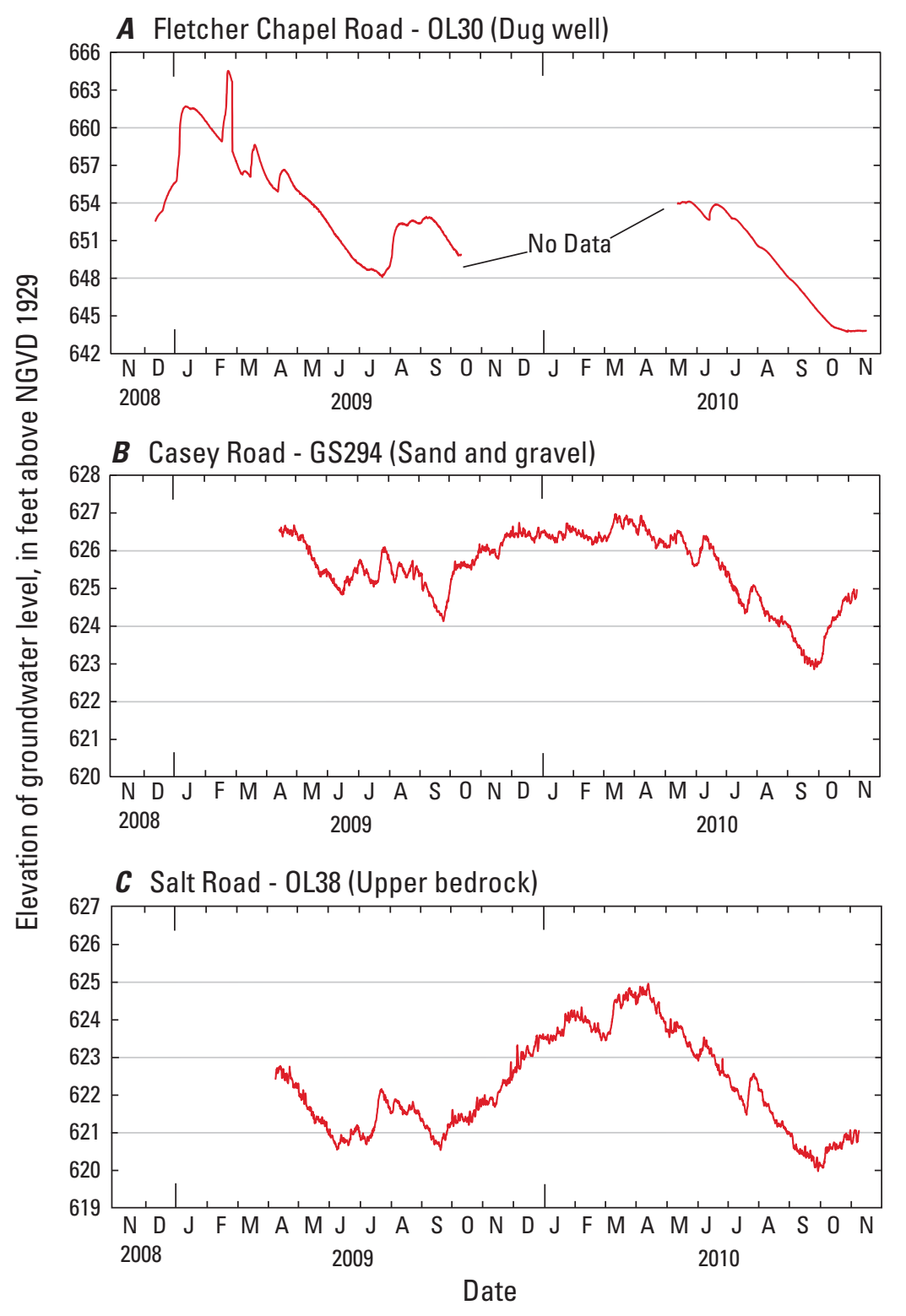

\section{EXPLANATION}

Water level—in feet above North American Vertical Datum 1929, in well or stream

Figure 2-1. Hydrographs of water levels in wells $A$, Fletcher Chapel Road, OL30; $B$, Casey Road, GS294; and C, Salt Road, OL38 in or near Iroquois National Wildlife Refuge, Orleans and Genesee Counties, New York, 2008-10. 


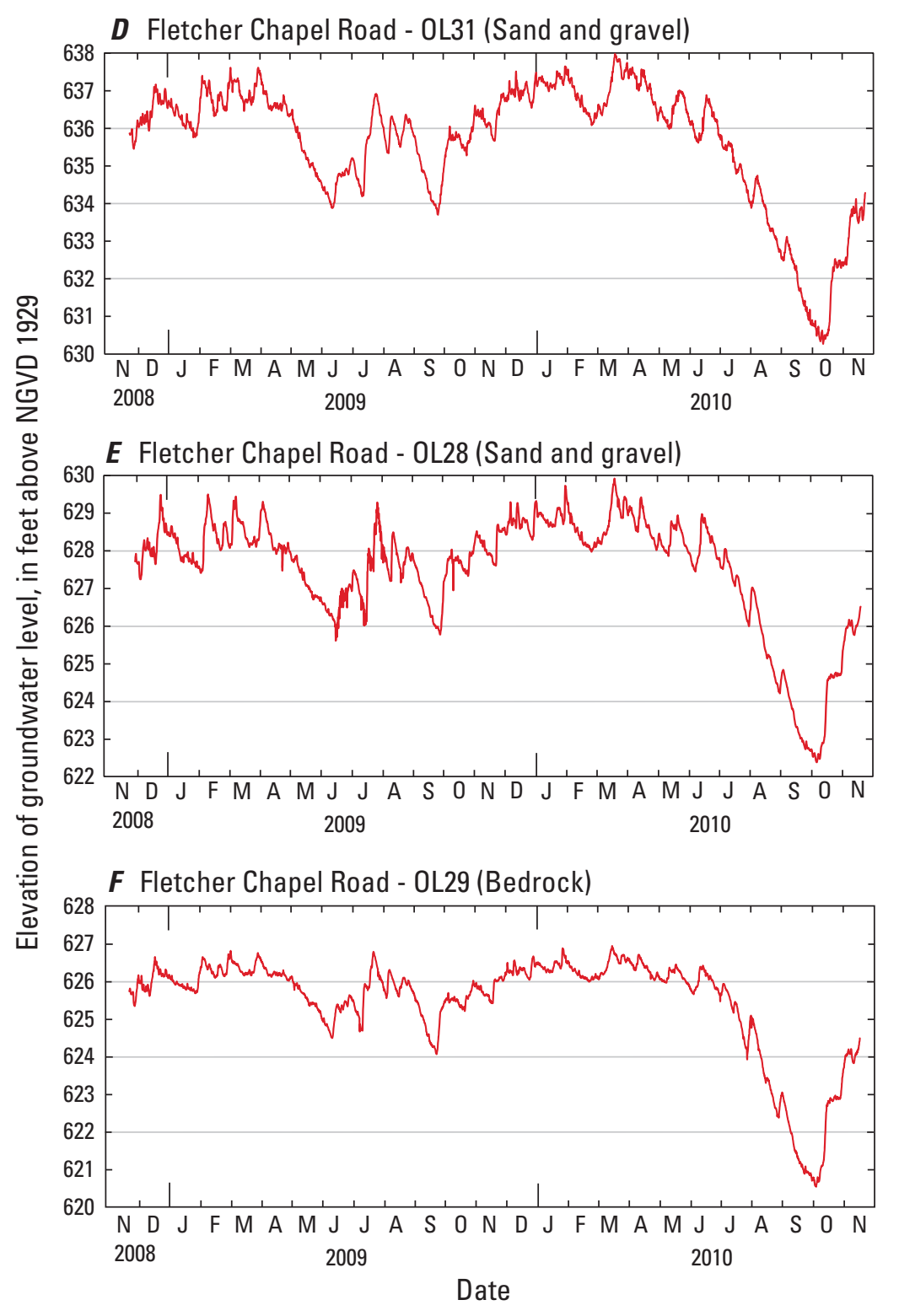

\section{EXPLANATION}

Water level-in feet above North American Vertical Datum 1929, in well or stream

Figure 2-2. Hydrographs of water levels in wells $D$, Fletcher Chapel Road, OL31; $E$, Fletcher Chapel Road, 0L28; and F, Fletcher Chapel Road, OL29 near Iroquois National Wildlife Refuge, Orleans County, New York, 2008-10. 


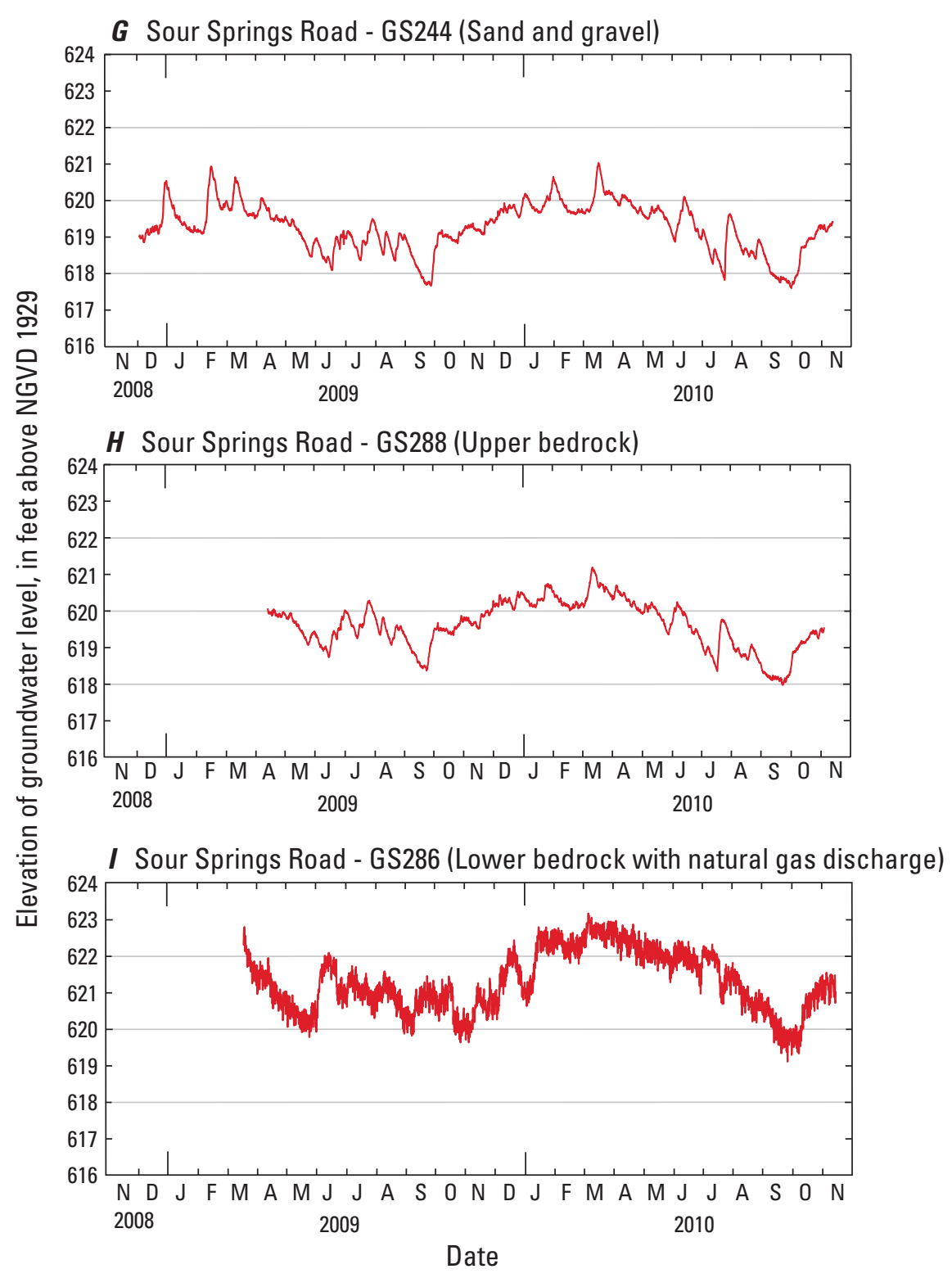

\section{EXPLANATION}

Water level—in feet above North American Vertical Datum 1929, in well or stream

Figure 2-3. Hydrographs of water levels in wells G, Sour Springs Road, GS244; H, Sour Springs Road, GS288; and I, Sour Springs Road-GS286 in Iroquois National Wildlife Refuge, Genesee County, New York, 2008-10. 


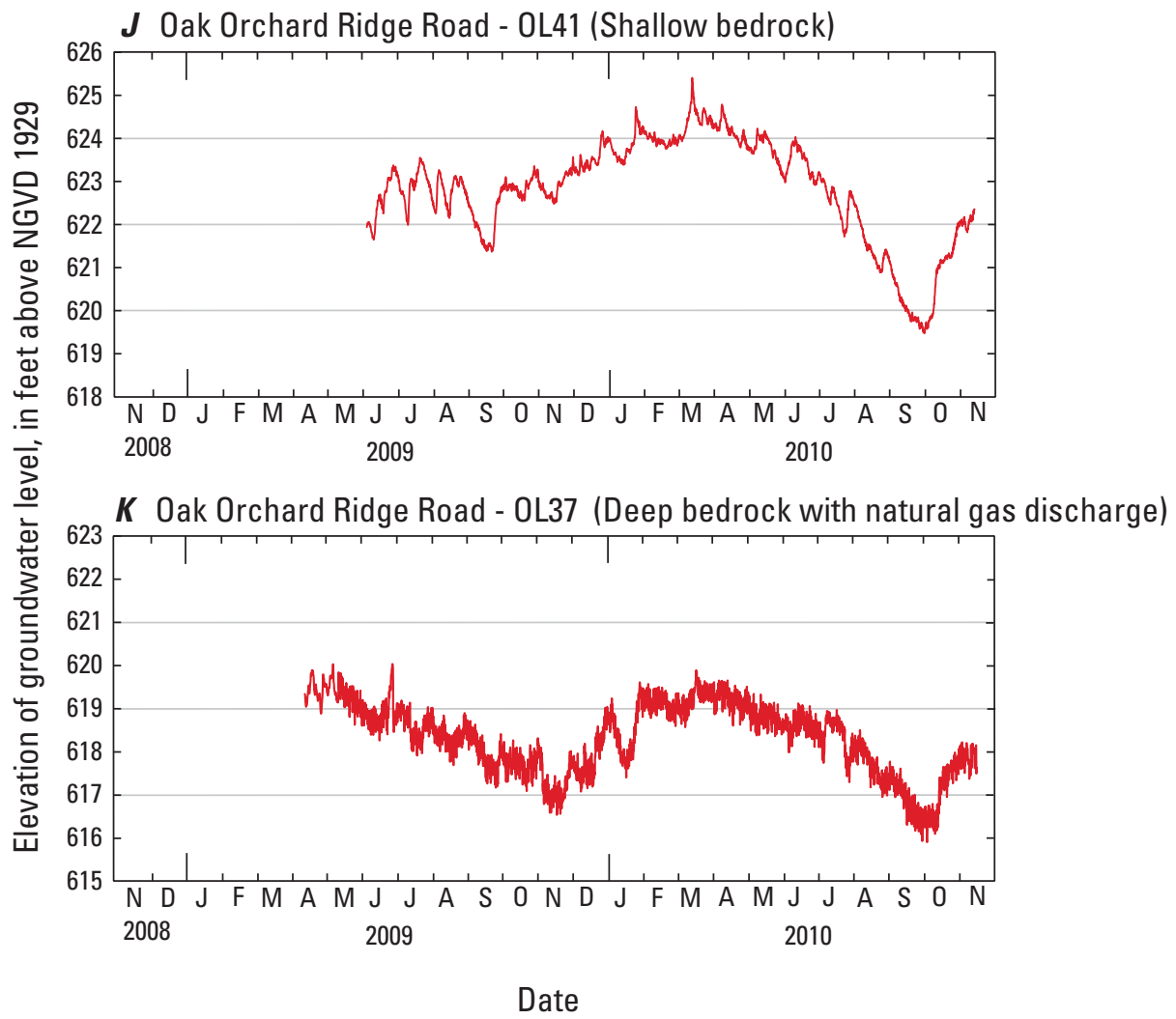

EXPLANATION

Water level—in feet above North American Vertical Datum 1929, in well or stream

Figure 2-4. Hydrographs of water levels in wells $J$, Oak Orchard Ridge Road, OL41; and $K$, Oak Orchard Ridge Road, OL37 in Iroquois National Wildlife Refuge, Orleans County, New York, 2008-10. 


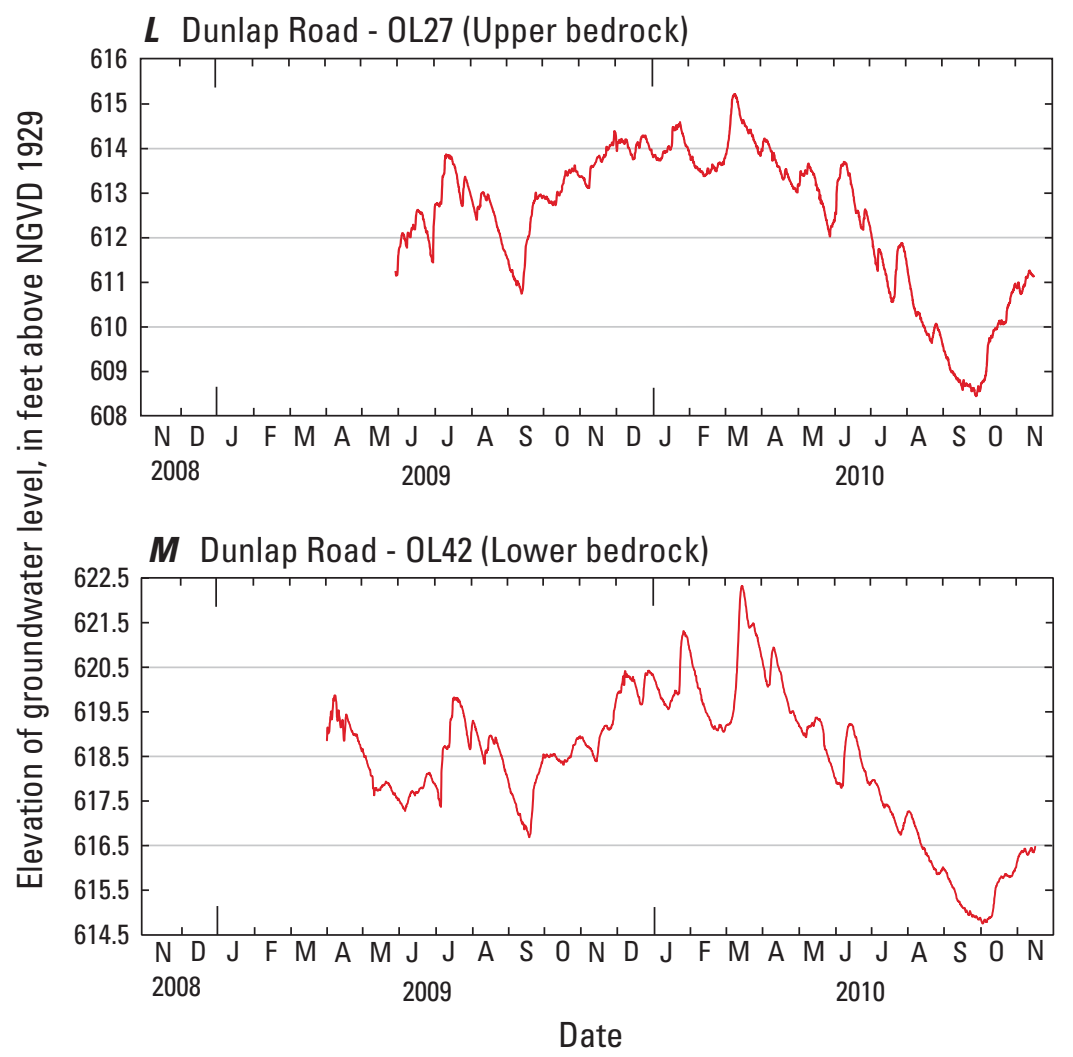

\section{EXPLANATION}

Water level—in feet above North American Vertical Datum 1929, in well or stream

Figure 2-5. Hydrographs of water levels in wells $L$, Dunlap Road, OL27; and $M$, Dunlap Road, OL42 in Iroquois National Wildlife Refuge, Orleans County, New York, 2008-10. 


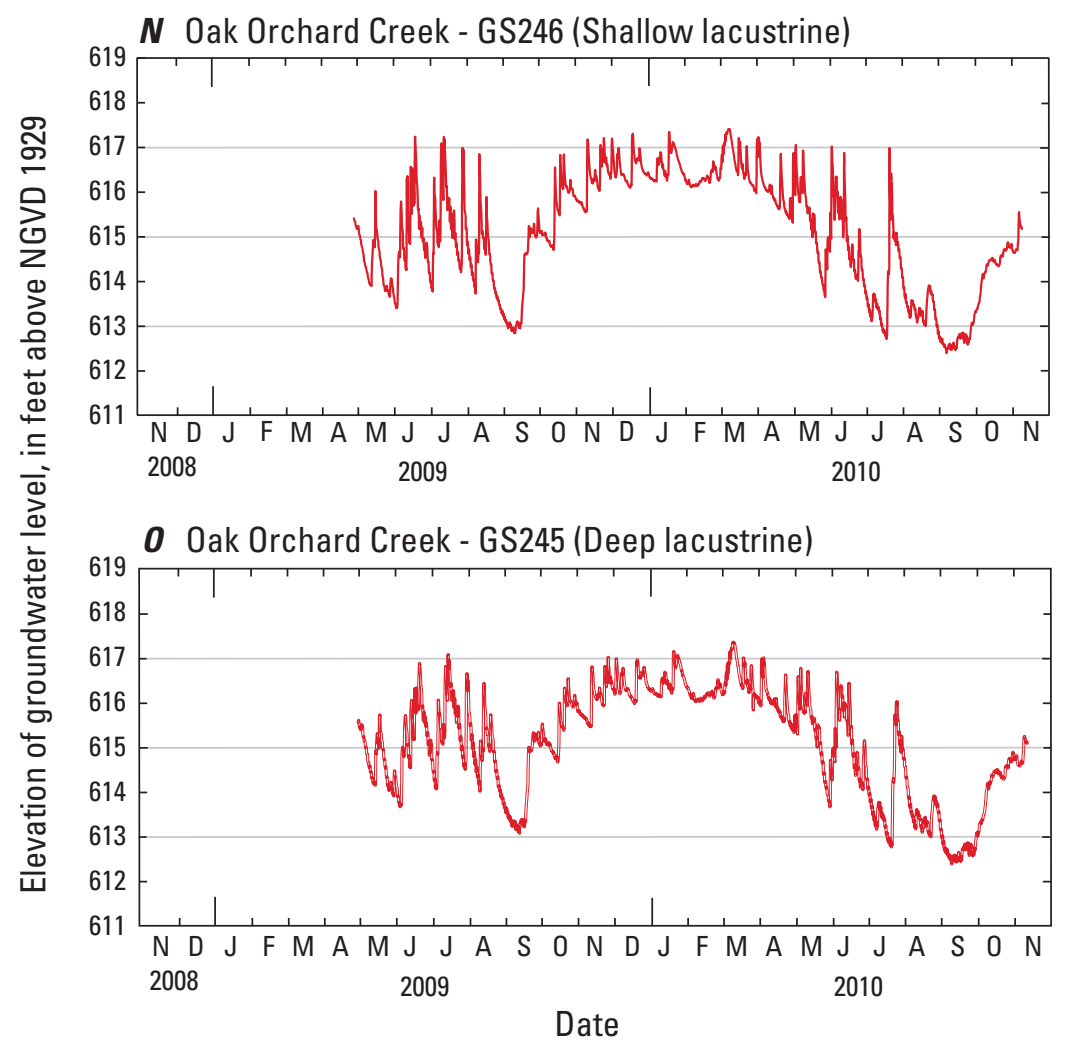

\section{EXPLANATION}

Water level—in feet above North American Vertical Datum 1929, in well or stream

Figure 2-6. Hydrographs of water levels in wells $N$, Oak Orchard Creek, GS246; and 0, Oak Orchard Creek, GS245 in Iroquois National Wildlife Refuge, Genesee County, New York, 2008-10. 

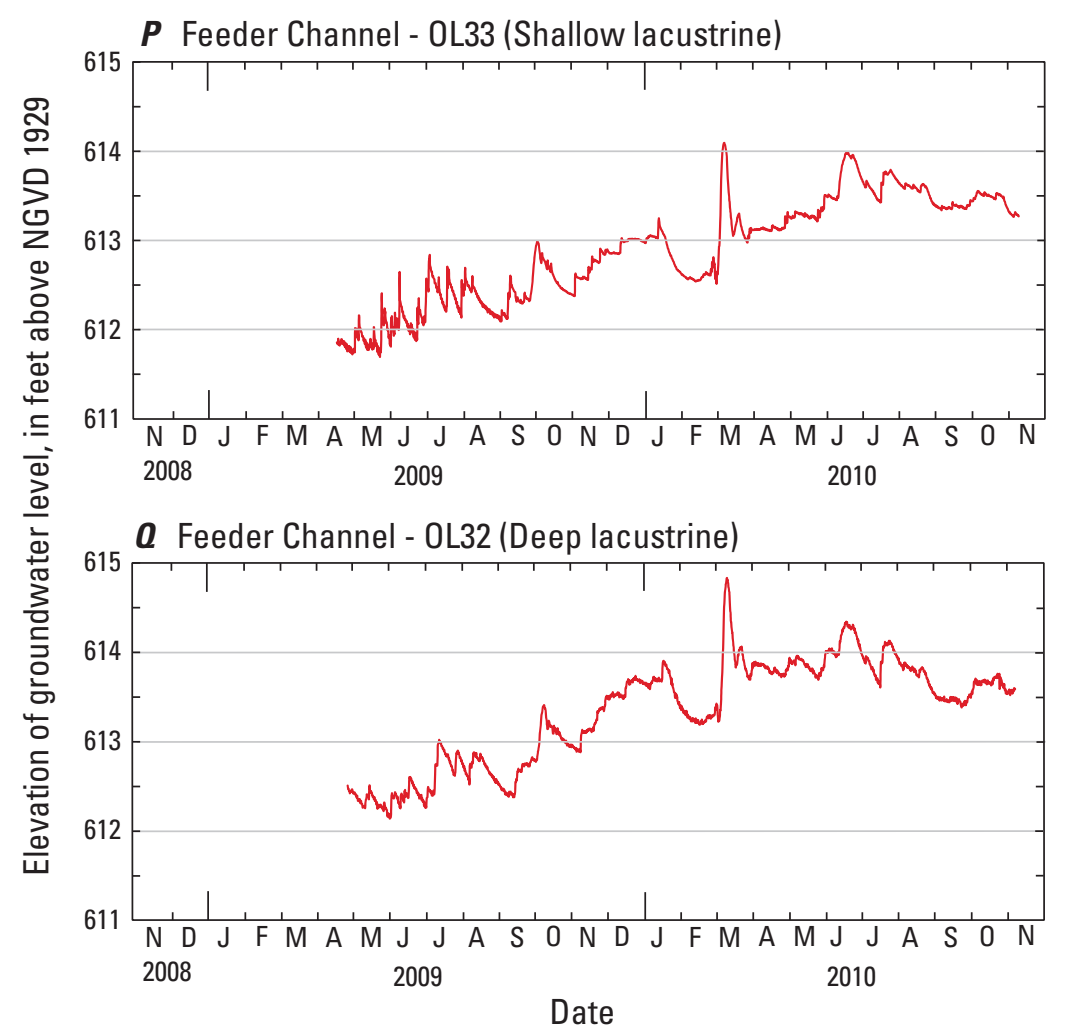

\section{EXPLANATION}

Water level-in feet above North American Vertical Datum 1929, in well or stream

Figure 2-7. Hydrographs of water levels in wells $P$, Feeder Channel, OL33; and $Q$, Feeder Channel, OL32 in Iroquois National Wildlife Refuge, Orleans County, New York, 2008-10. 


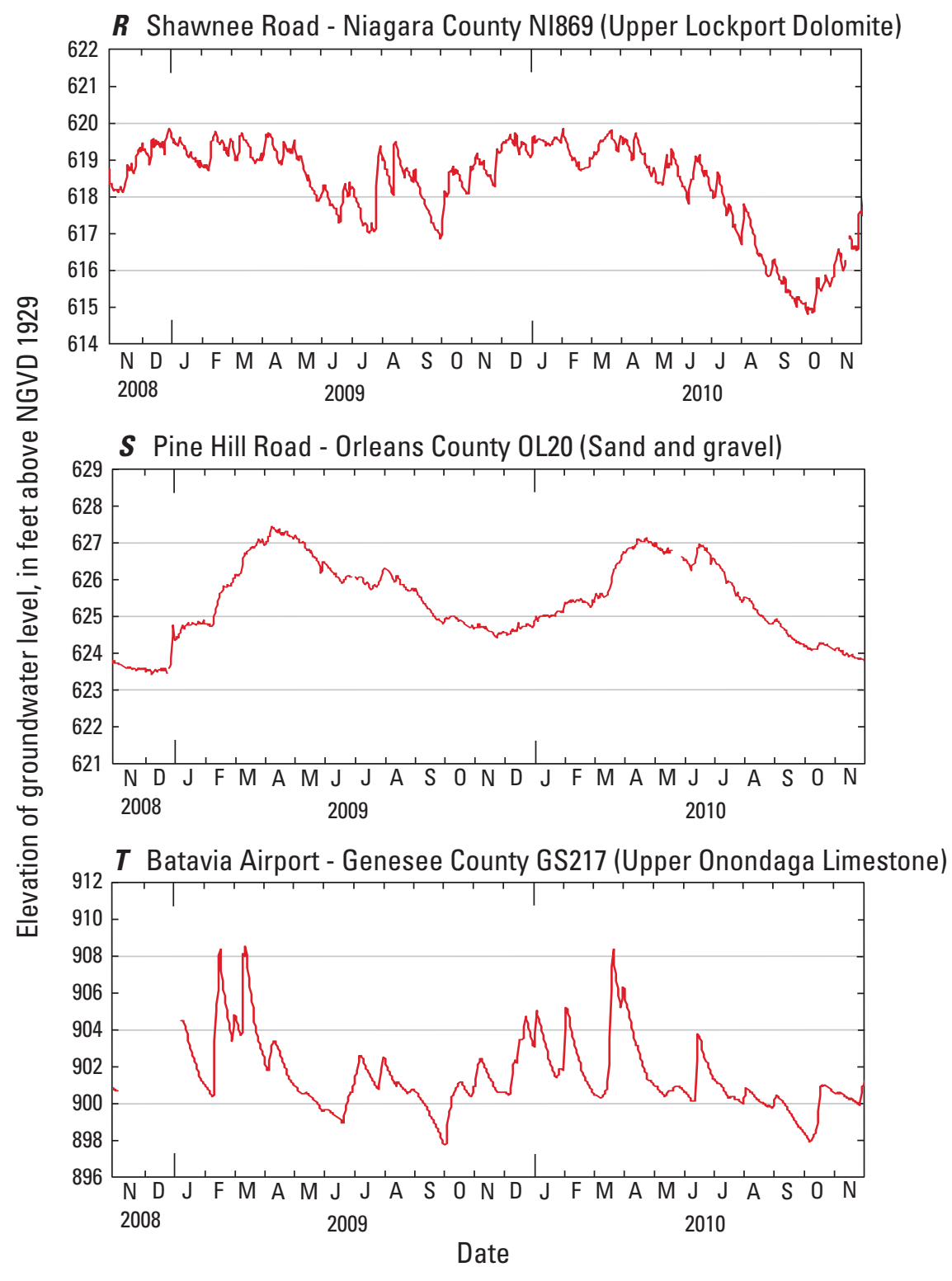

EXPLANATION

- Water level—in feet above North American Vertical Datum 1929, in well or stream

Figure 2-8. Hydrographs of water levels in regional wells $R$, Shawnee Road, NI869; S, Pine Hills Road, OL20; and T, Batavia Airport, GS217 in Niagara,

Orleans, and Genesee Counties, New York, 2008-10. 


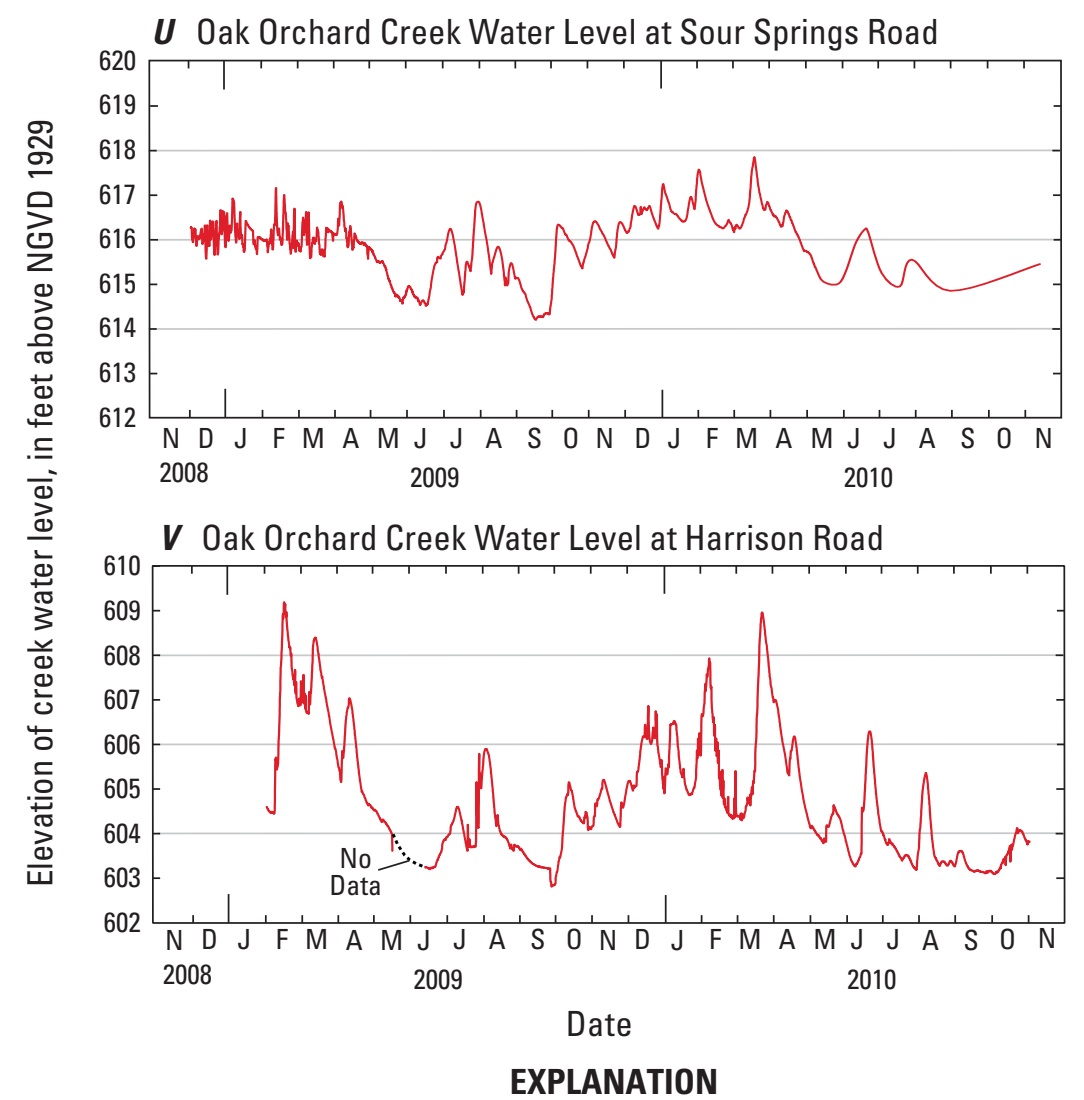

Water level—in feet above North American Vertical Datum 1929, in well or stream

Figure 2-9. Stream hydrographs in U, Oak Orchard Creek at Sour Springs Road; and V, Oak Orchard Creek at Harrison Road in or near Iroquois National Wildlife Refuge, Genesee and Orleans Counties, New York, 2008-10. 


\section{Appendix 3. Borehole Geophysical Logs for Four Test Holes - OL27-Dunlap Road, OL37-Oak Orchard Ridge Road, OL38-Salt Road, and GS286-Sour Springs Road-Drilled in the Iroquois National Wildlife Refuge, Genesee and Orleans Counties, New York.}

${ }^{1}$ Blue square indicates ambient stationary measurement; blue line indicates ambient trolling measurement; red open square indicates pumped stationary measurement; red line indicates pumped trolling measurement; downward flow is negative; upward flow is positive. 
翠
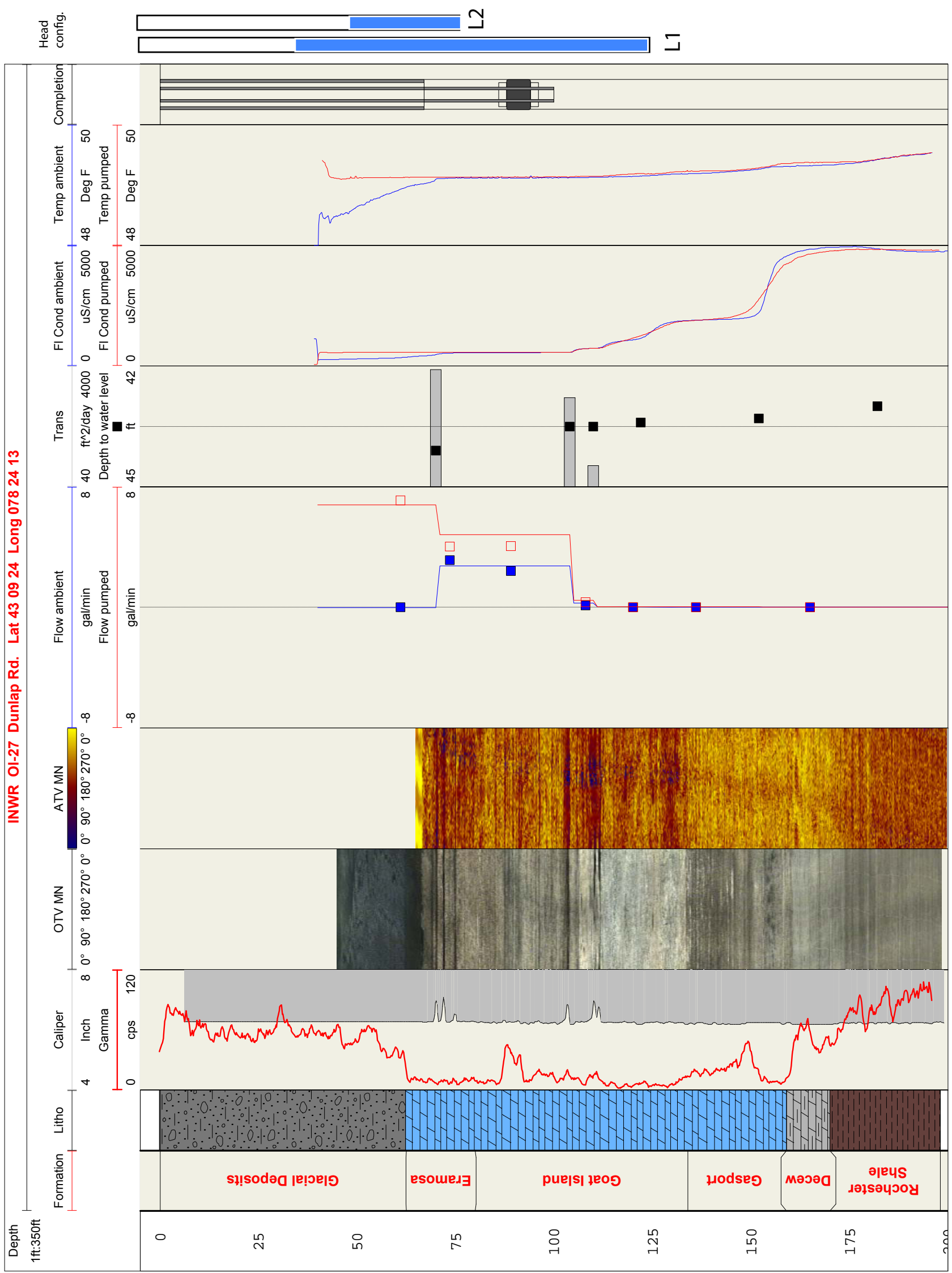


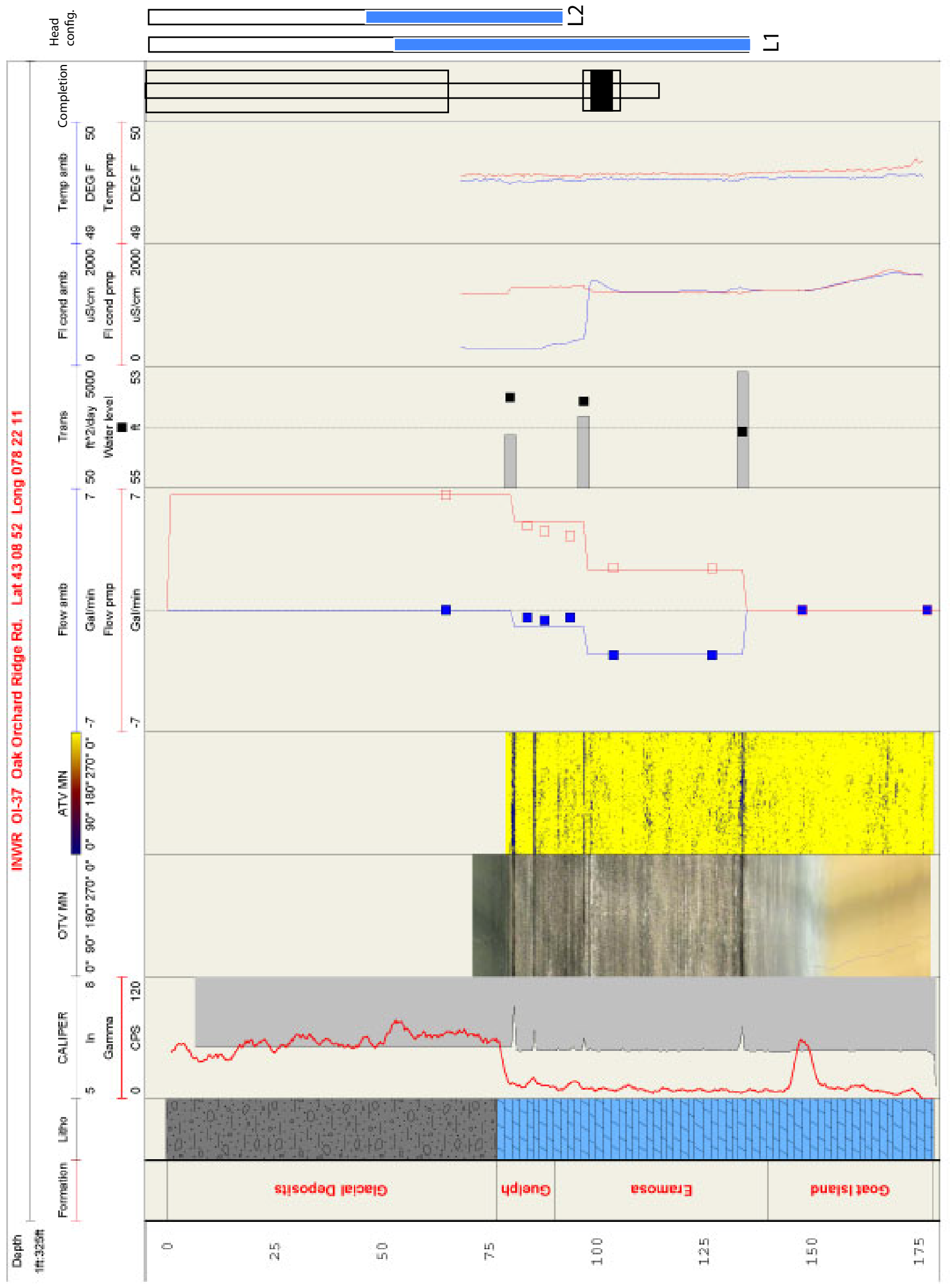

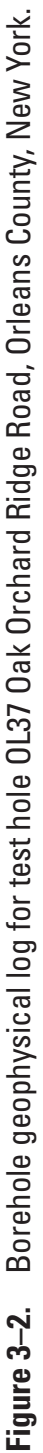




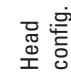

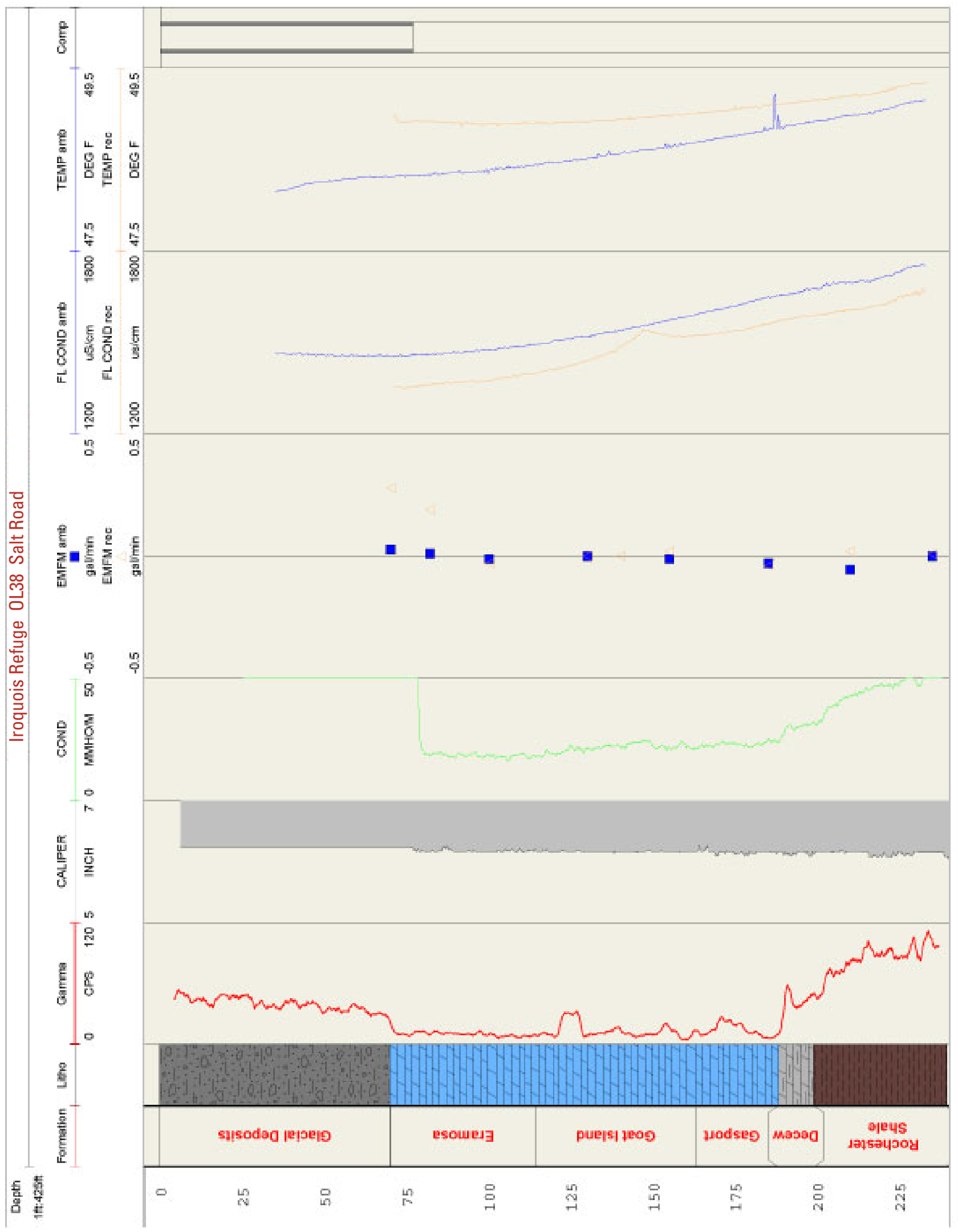




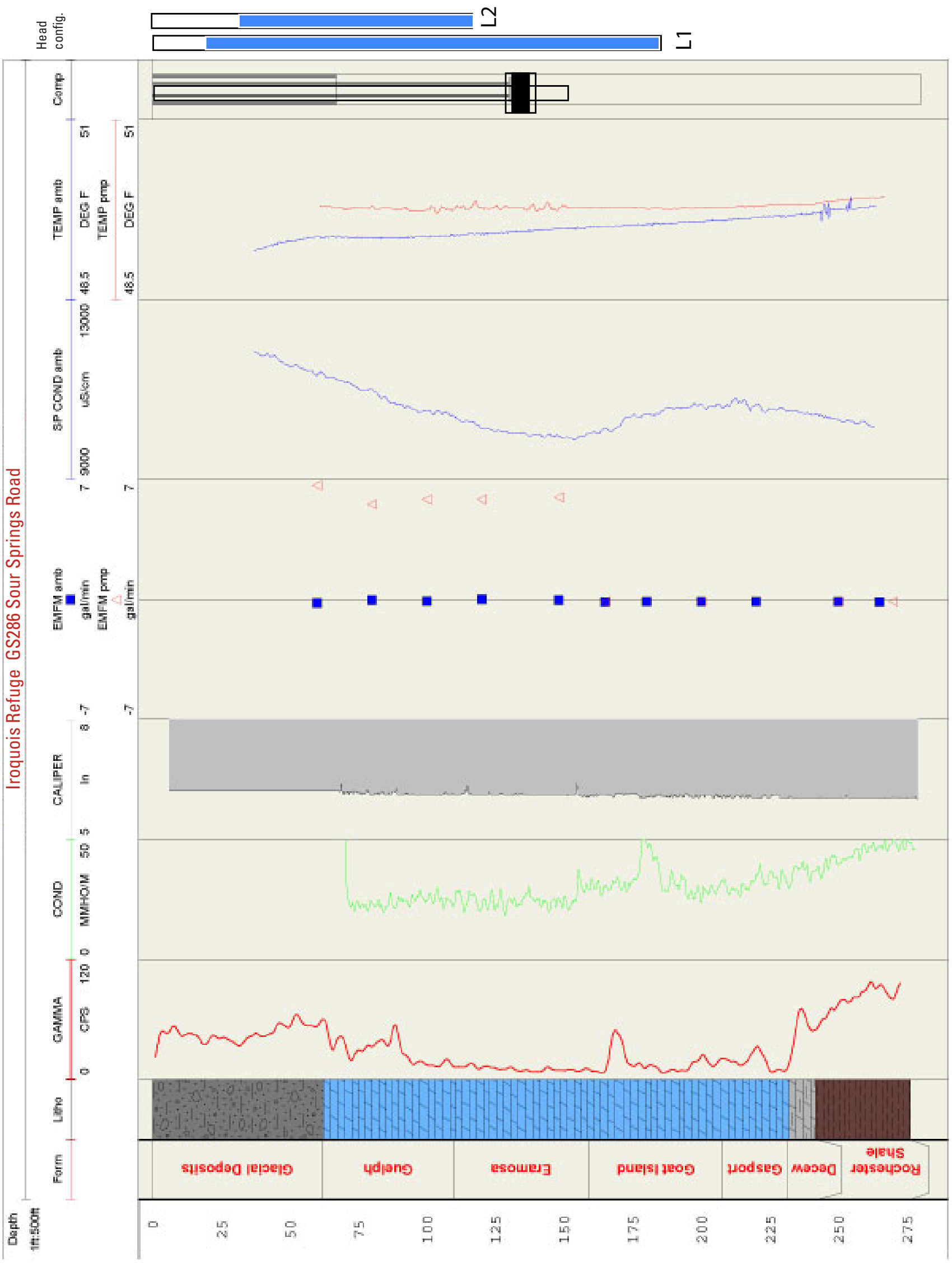

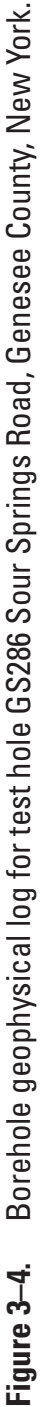


This page has been left blank intentionally. 
Prepared by the Pembroke Publishing Service Center.

For additional information write to:

New York Water Science Center

U.S. Geological Survey

30 Brown Rd.

Ithaca, NY 14850

Information requests:

(518) 285-5602

or visit our Web site at: http://ny.water.usgs.gov 
崽

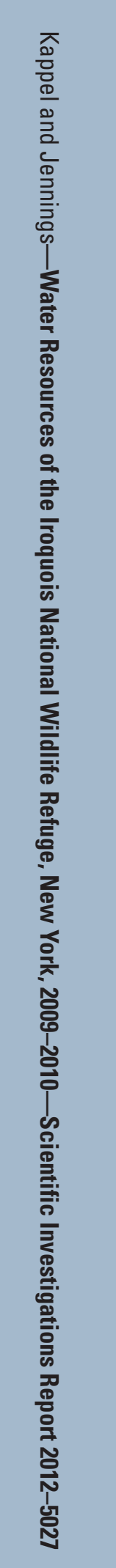

